\title{
Experimental and Modeling Studies of the Effects of Nanoclay on the Oil Behaviors in A Water-Sand System
}

\author{
Rezvan Iravani \\ A Thesis \\ in \\ The Department \\ of \\ Building, Civil and Environmental Engineering \\ Presented in Partial Fulfillment of the Requirements \\ for the Degree of Master of Applied Science (Civil Engineering) at \\ Concordia University \\ Montreal, Quebec, Canada
}

December 2020

CRezvan Iravani, 2020 


\section{CONCORDIA UNIVERSITY}

School of Graduate Studies

This is to certify that the thesis prepared

By: $\quad$ Rezvan Iravani

Entitled: $\quad$ Experimental and Modeling Studies of the Effects of Nanoclay on the Oil Behaviors in a Water-Sand System

and submitted in partial fulfillment of the requirements for the degree of

\section{Master of Applied Science (Civil Engineering)}

Complies with the regulations of the University and meets the accepted standards with respect to originality and quality.

Signed by the final examining committee:

Chair

Zhi Chen

Internal Examiner

Zhi Chen

External Examiner

Chynyan Lai

Supervisor

Chunjiang An

Approved by Chair of Department or Graduate Program Director Ashutosh Bagchi 2020 Dean of Faculty

Mourad Debbabi 


\title{
ABSTRACT \\ Experimental and Modeling Studies of the Effects of Nanoclay on the Oil Behaviors in A Water-Sand System
}

\author{
Rezvan Iravani
}

\begin{abstract}
When oil is spilled into the marine environment, a certain amount of spilled oil may finally reach the shoreline. This study comprehensively explored the effects of bentonite nanoclay on the oil behaviours in water-sand media from both experimental and modeling perspectives. Four factors including nanoclay concentration, temperature, salinity and $\mathrm{pH}$ have been studied. The increasing nanoclay concentration resulted in the decrease in remaining oil on sand. Higher temperature and salinity were associated with less residual oil on sand in the presence of nanoclay. The lower residudual oil on sand with coexisitng nanoclay was found to be at $\mathrm{pH}$. The factorial analysis results indicated that the nanoclay concentration showed the most significant impact among these factors. Miscibility modeling resutls showed an increasing temperature was favorable to the nanoclay miscibility. Moreover, the effect of nanoclay on oil behaviro was further revealed through the dynamic simulation, in which it can be seen the nanoclay could penetrate into oil droplets and promote the detachment of oil from the solid substrate. The results of this study can help understand the role of fine particles in the fate and transport of oil on shoreline, and support the risk assessment and response planning after oil spill.
\end{abstract}




\section{ACKNOWLEDGEMENTS}

I would like to appreciate my principal advisor Dr. Chunjiang An for his guidance, compassionate support, and encouragement throughout this research. As a thesis supervisor, Professor An supported me in all stages of this work. He is the initiator of this project and he always gave me constant encouragement and advice. Without a coherent and illuminating instruction, this thesis would not have reached its present form.

I would also like to thank Dr. Kaiqiang Zhang for his helps on the experiment and modelling data. I would also express my thanks to my friend Zhikun Chen in Concordia University for his assistance in various aspects of my research and for his support with constant friendship.

I would like to thank specially to the man who support me every single second, not only in my personal life but in my education period. My husband, Mojtaba Mohammadi, is a compassionate supporter in my life who guide me with all his patience. This accomplishment would not have been possible without him.

Finally, I must express my very profound gratitude to my parents for providing me with unfailing support and continuous encouragement throughout my years of study and through the process of researching and writing this thesis from far distance. 


\section{TABLE OF CONTENTS}

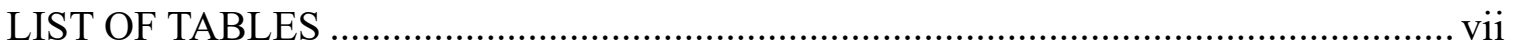

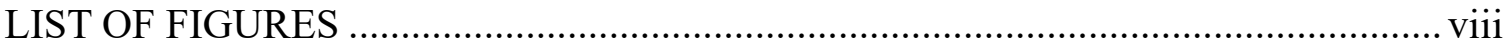

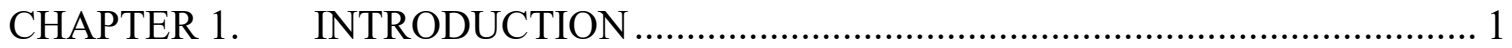

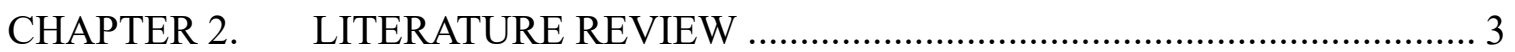

2.1. General introduction of nanoclays........................................................... 3

2.2. Physicochemical characteristics of nanoclays ................................................. 4

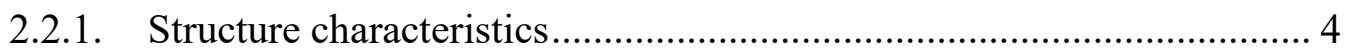

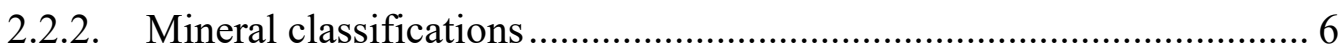

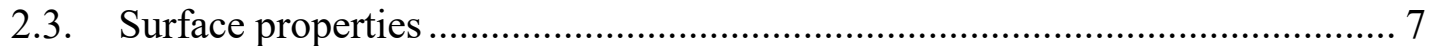

2.4. Use of nanoclays in industrial processes ...................................................... 8

2.4.1. Use as rheological control agent..................................................... 9

2.4.2. Use in food packaging ................................................................. 9

2.4.3. Use in biomedical applications and drug delivery .............................. 10

2.5. Applications of nanoclays in pollutant removal from water ...........................11

2.5.1. Removal of pharmaceutical compounds from water ............................ 12

2.5.2. Removal of dyes from water ........................................................... 13

2.5.3. Removal of heavy metals from water............................................... 16

2.5.4. Removal of pesticides from water ..................................................... 17

2.5.5. Removal of inorganic compounds from water ................................... 19

2.6. Applications of nanoclays in gas emission control ....................................... 22

2.6.1. Applications in $\mathrm{H}_{2} \mathrm{~S}$ removal ...................................................... 23

2.6.2. Applications in $\mathrm{CO}_{2}$ capture ......................................................... 24

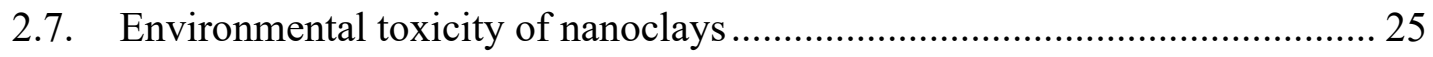

2.7.1. Toxicological evaluation methods ..................................................... 26

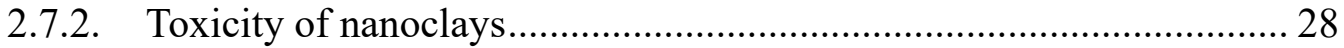

2.7.3. Toxicity mechanism......................................................................... 29

CHAPTER 3. MATERIALS AND METHODS ……………………………......... 31

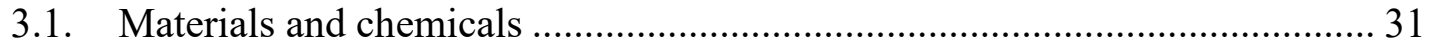

3.2. Experimental procedure ......................................................................... 31 


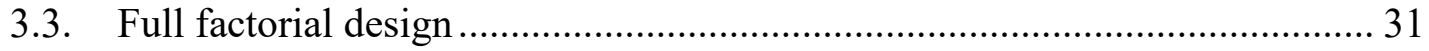

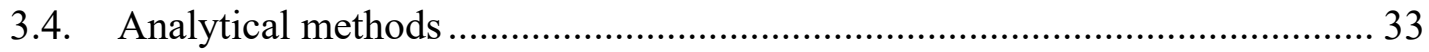

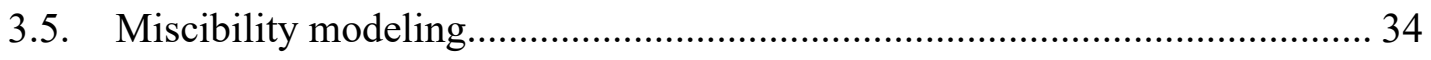

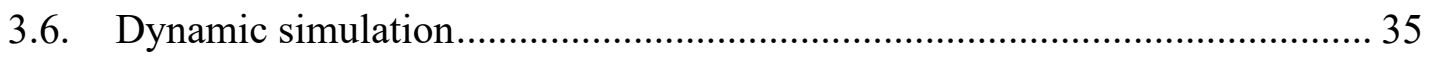

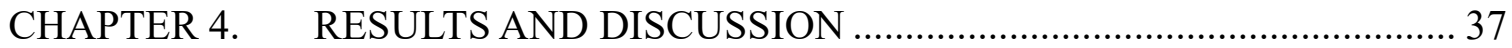

4.1. The effect of nanoclay concentration on oil behavior ................................ 37

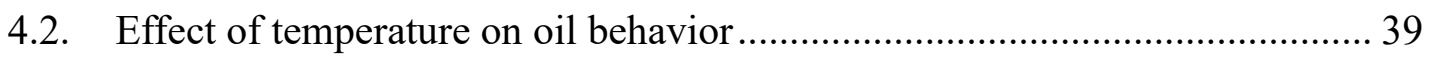

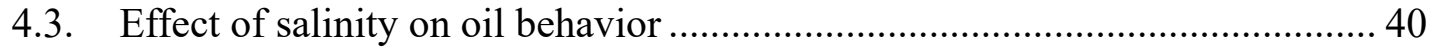

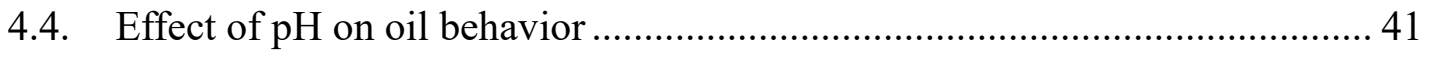

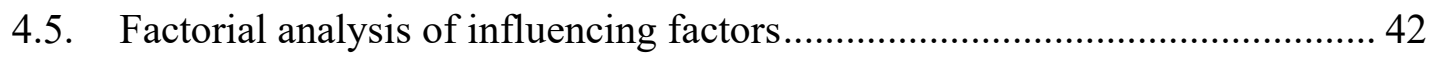

4.6. Insight from miscibility modeling study ................................................. 44

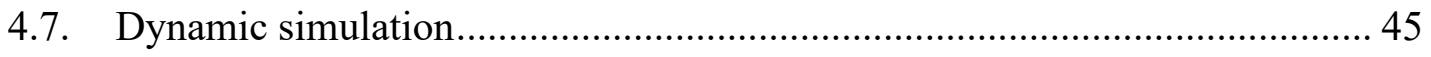

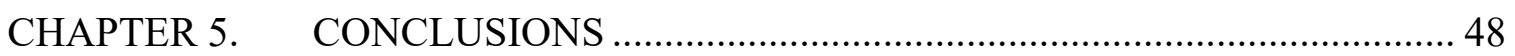

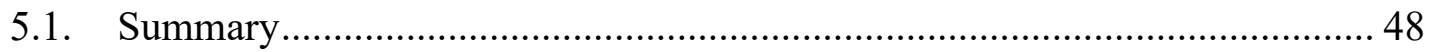

5.2. Recommendations for future study .................................................... 49 


\section{LIST OF TABLES}

Table 2-1. Classification of clay minerals based on the layer type and charge per formula

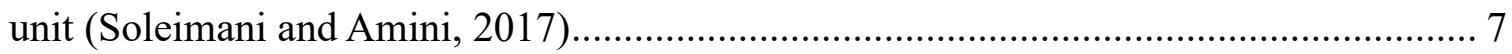

Table 2-2. Analysis of nanomaterials properties required for toxicity evaluation (M.

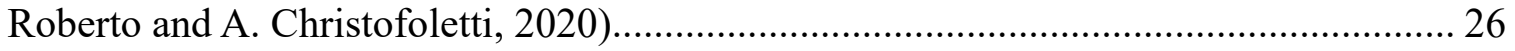

Table 2-3. Different Toxicity evaluation test (Rai and Biswas, 2019) ........................... 27

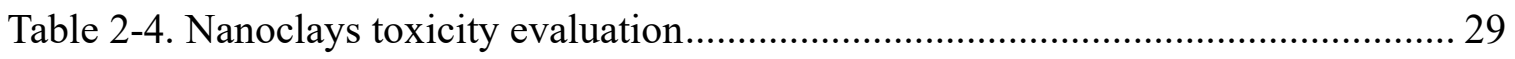

Table 3-1. Experimental variable factors for chemical properties of flush water............ 32

Table 3-2. Corresponding values for factorial design matrix....................................... 32 


\section{LIST OF FIGURES}

Figure 2-1. Crystal structures of clay minerals (a) Type 1:1; (b) Type 2:1 (Jlassi et al., 2017)

Figure 2-2. Typical AFM images of (a) bentonite, (b) montmorillonite, (c) kaolin, (d) halloysite, (e) silica, and (f) graphene oxide nanoparticles (Mousavi et al., 2018) ........... 6 Figure 2-3. Interaction of montmorillonit (MMT) and halloysite with drug (Khatoon et al., 2020)

Figure 2-4. Adsorption of pollutants at the different surface locations of nano-clay (Awasthi et al., 2019) 12

Figure 2-5. Removal of heavy metals from water using nanoclays (Uddin, 2017) 17

Figure 2-6. Schematic of toxicity mechanism caused by cellular subjection to nanoclay (Wagner, 2018). 30

Figure 3-1. Snapshot of the oil on the solid substrate with montmorillonite particle....... 36

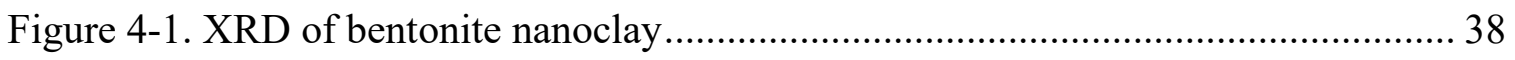

Figure 4-2. The effect of nanoclay concentration on oil behavior................................ 38

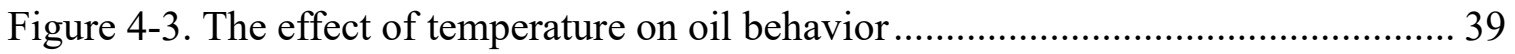

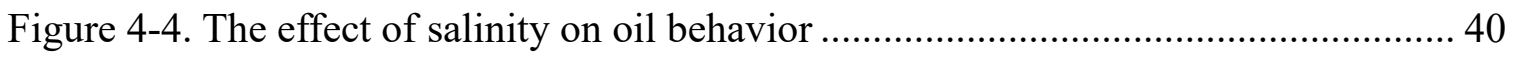

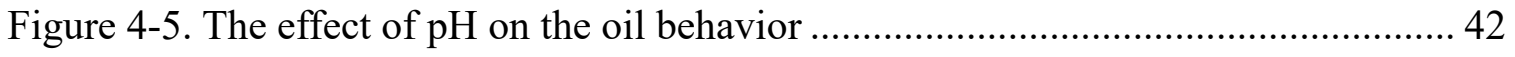

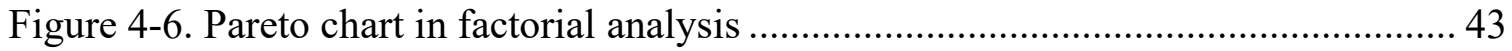

Figure 4-7. (A-D) Plots of the single factors effect, (E-G) Plots of effective double factors

Figure 4-8. Calculated free energy of mixing versus nanoclay concentration at various temperature from 5 to $30^{\circ} \mathrm{C}$

Figure 4-9. Snapshots of the spontaneous detachment of an oil droplet from a modeled solid substrate with nanoclay particles 47 


\section{CHAPTER 1. INTRODUCTION}

Oil spill is a serious environmental problem that results from oil drilling, pipeline leakage, and tank accidents (An et al., 2017; Cai et al., 2019; Chen et al., 2019; Lucas and MacGregor, 2006). When oil is spilled into the marine environment, a certain amount of spilled oil may finally reach the shoreline (Helle et al., 2015; Sarbatly et al., 2016). The shorelines will be contaminated if there is no promote response. The stranded oil on shoreline may cause detrimental effects on coastal biota and colonies (Li et al., 2018; Owens et al., 2008; Zhang et al., 2018). Understanding the oil behaviors in shoreline is important for assessing the environmental risk and development the appropriate response strategy (Cao et al., 2020). The transport and fate of oil in the shoreline are a complex process which includes many physiochemical and biological actives. The composition and characteristic of oil on shoreline can change during weathering, evaporation, dissolution, and wave exposure. Due to the spatial and temporal variation of oil spills, the environmental conditions also play an important role in the oil behavior on beaches. The interaction of different environmental conditions can also affect the residual oil on shoreline after spills.

Clay is a major component of shoreline sediments. Clay particles are featured by the layered structure and large specific surface area (Soleimani and Amini, 2017). For example, montmorillonite (Mt) is a typical 2:1 type clay mineral which has a good cation exchange capacity (CEC) and layer expansion capacity (Brigatti et al., 2013). Mt itself can be used as high efficient adsorbent for the removal of heavy metals, organic pollutants, and nutrients from water (Churchman et al., 2006). It can also be easily modified (e.g., intercalating with cationic modifiers, thermal treatment, acid washing) to synthesize various adsorbents. It was reported that the hydrophobic organoclays modified from hydrophilic bentonites using quaternary amines could be used as efficient and selective adsorbent for removing oi from water (Adebajo et al., 2003; Carmody et al., 2007). Nanoclay usually has the size ranging from $70-150 \mathrm{~nm}$ in diameter (Uddin, 2008). Various types of nanoclay have been studied in terms of environmental pollution mitigation or remediation (Abdelaal, 2004). Several polymer-nanoclay composites were found to be 
effective in the removal of pollutants from aqueous solutions in water treatment processes (Guo et al., 2018). Although these studies are encouraging, the role of nanoclay in the natural environment is not well understood. It is expected to know how the existence of nanoclay can impact the oil behaviors in the shoreline environment.

Oil spill is one of the most significant environmental issues around the world. Once the oil is on the shoreline, it is expected to know the fate and transport of oil. Clay exists widely in the shoreline environment, understanding the impact of nanoclay on oil behaviors can help determine the risk of spilled oil on shoreline. In this study, therefore, the experimental and modeling studies will be conducted to investigate the effects of nanoclay on the oil behaviors in a water-sand system. The processes under different shoreline environmental conditions including nanoclay concentration, temperature, salinity, and $\mathrm{pH}$ will be considered. The factorial analysis will be used to further determine the main effects and interactions of these factors. The miscibility modeling and molecular dynamics simulation will also be used for better understanding the effect of nanoclays. The results have significant implications for the assessment of oil spill risk in the shoreline and the development of cleanup strategy. There are three objectives have been proposed as follows: (i) conduct comprehensive literature review to have in-depth understanding of the nature and different applications of various types of clays (CHAPTER 2), (ii) design the experiments and conduct modeling works to check the oil behaviour under different circumstances (CHAPTER 3), and (iii) discuss the results to explore the effects of nanoclay on the oil behaviors in a water-sand system (CHAPTER 4). 


\section{CHAPTER 2. LITERATURE REVIEW}

\subsection{General introduction of nanoclays}

Clay is a natural substance widely existing in sediments (Theng and Walker, 1970). Clay minerals are a sort of phyllosilicates that are naturally derived from chemical weathering of other silicate minerals (Bergaya and Lagaly, 2006; Choy et al., 2007). Clay minerals, which are naturally abundant and known as highly reactive geomaterials, have been used for various purposes. For instance, clays have been utilized in farm animal nutrition as binding agents and feed additives to promote growth and health, and as a supplement to treat gastrointestinal disorders(Motta et al., 2007; Slamova et al., 2011). Clays have moreover been utilized within the generation of commodities such as ceramics, bricks, pottery, and medicines (Choy et al., 2007; Motta et al., 2007; Newman and Cragg, 2007).

Generally, nanoclays are clay particles with at least one dimension in the nano range. Among all types of natural substances, montmorillonite and allophane are most broadly used. In comparison to other nanomaterials, nanoclays have been utilized widely in various studies due to their particular physicochemical properties. Typically, these substances have a small particle size, large surface area, and high porosity. Being nontoxic, inexpensive, and having a positive cation exchange capacity (CEC), these materials are a suitable option for a range of environmental applications (Soleimani and Amini, 2017). They have typically been used in adsorption to remove hazardous contaminants such as heavy metals, antibiotics, and phenol. Application of nanoclays in gas treatment has also been studied, as has the performance of nanoclays in $\mathrm{CO}_{2}$ capture and $\mathrm{SO}_{2}$ removal.

The modification of nanoclays can bring some other features for their application. Intercalation of quaternary ammonium cations can result in the formation of organicallymodified montmorillonite, which has been utilized as a rheological modifier or additive in paints, inks, oils, and beauty care products. Allophane, meanwhile, is a non-crystalline aluminosilicate found in volcanic ash. This nanoclay has been applied for environmental 
utilization such as the removal of phenolic and phosphate compounds from water (Calabi Floody et al., 2009). This article aims to provide a comprehensive review of the specific characteristics of different types of nanoclays. The industrial applications of nanoclays will be summarized. The environmental applications of nanoclays for water and air treatment, as well as their toxicity will be discussed. Finally, the challenges and recommendations for future study will be proposed.

\subsection{Physicochemical characteristics of nanoclays}

\subsubsection{Structure characteristics}

Clay minerals are known as layered substances consisting of the sheets of silicate tetrahedra (SiO4) and octahedra (containing $\mathrm{Al}, \mathrm{Mg}$, and $\mathrm{Fe}$ ). Layered structural units each with a layer thickness of around one to a few nanometers. The lateral dimensions of these layers are varying from $30 \mathrm{~nm}$ to several microns which gives a ratio of length to thickness greater than 1,000 (Martin, 1991). The particular structure of a nanoclay layer is like a small plate comprising several crystal sheets having a replicate atomic structure of alumina and silica sheets (Fig. 2-1). Each alumina sheet (i.e., octahedral) consists of six hydroxyl ions or oxygen atoms enclosing a metal atom such as aluminum, iron, or magnesium $(\mathrm{Xu}$ and $\mathrm{Lu}$, 1997). Each silica sheet (i.e., tetrahedral), meanwhile, consists of four oxygen atoms linked to an adjacent tetrahedral by sharing three corners. The basic building framework of all clay minerals is the same and consists of tetrahedral and octahedral sheets linked together in a particular way to create a nano-structure. The fundamental unit of clay mineral particles consists of nanoparticle aluminosilicates with an outer diameter in the range of $3.5 \mathrm{~nm}$ to $5.0 \mathrm{~nm}$ (Brigatti et al., 2013). The primary layers of smectite, for example, as a clay mineral, have a width of about $1 \mathrm{~nm}$ and a length of approximately $100 \mathrm{~nm}$ (Yuan, 2004). 


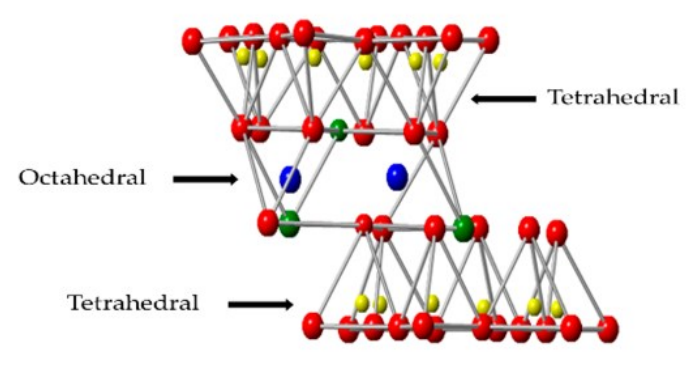

(a)

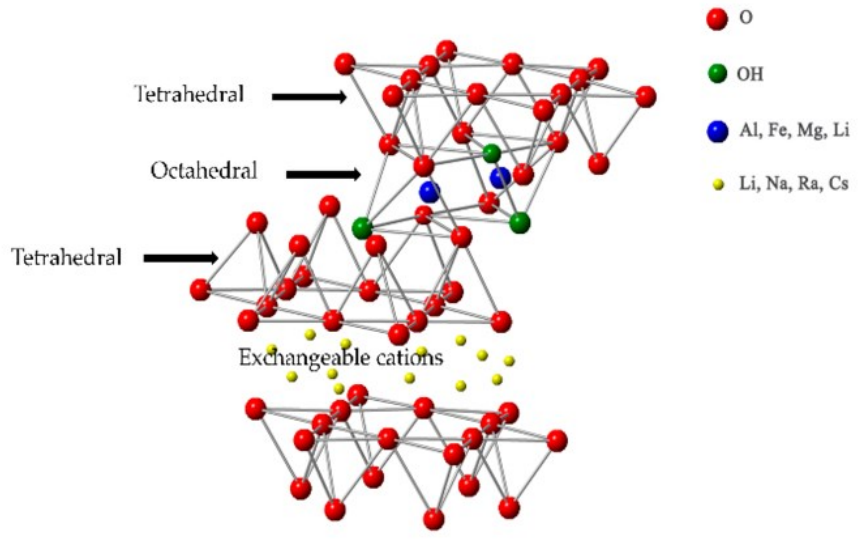

(b)

Figure 2-1. Crystal structures of clay minerals (a) Type 1:1; (b) Type 2:1 (Jlassi et al., 2017)

Bentonite, montmorillonite, and kaolin are platy clay particles ranging from nanometers to micrometers, whereas halloysite nanotubes are hollow rod-like particles having a lumen diameter of $\sim 20 \mathrm{~nm}$ and a tube length ranging from $300 \mathrm{~nm}$ to $2 \mu \mathrm{m}$. Spherical silica nanoparticles were also used as a material mimicking the outer silica layer of the clays. Graphene oxide nanosheets having the shape and size close to smectite clays. The typical AFM images demonstrating the geometry and sizes of nanoparticles, are given in Fig. 2-2 (Mousavi et al., 2018). 


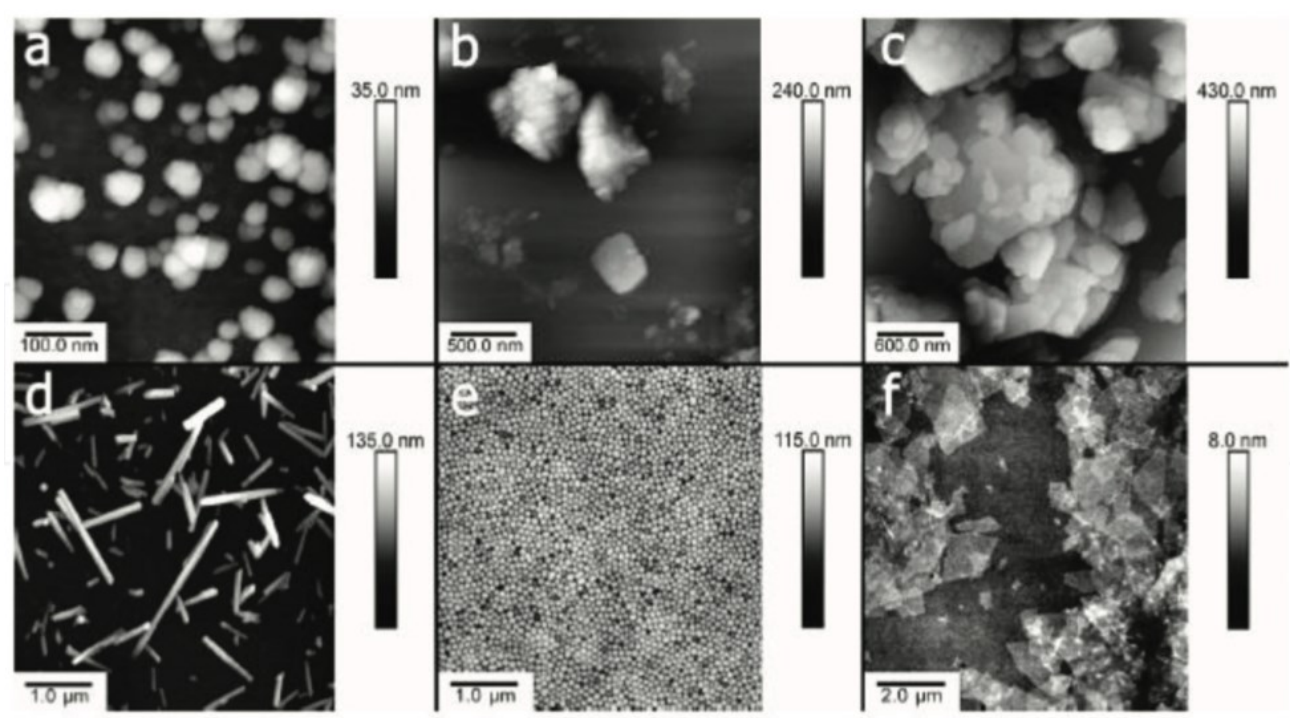

Figure 2-2. Typical AFM images of (a) bentonite, (b) montmorillonite, (c) kaolin, (d) halloysite, (e) silica, and (f) graphene oxide nanoparticles (Mousavi et al., 2018)

\subsubsection{Mineral classifications}

Based on the special specifications of clay minerals such as chemical composition, structural characteristics, and net charge, they can be usually classified into seven groups: (1) kaolin-serpentine, (2) pyrophyllite-talc, (3) smectite, (4) vermiculite, (5) mica, (6) chlorite, and (7) interstratified clay minerals (Martin, 1991). Another classification of clay minerals, based on layer type and charge per formula unit, has been proposed as outlined in Table 2.1. In this classification, the minerals in the simplest group are composed of sheets each comprising 1 tetrahedral and 1 octahedral unit, and as such they are considered a 1:1 mineral (e.g., in kaolinite). In the 2:1 phyllosilicate type of nanoclay, an octahedral alumina sheet is surrounded by two tetrahedral silica sheets through electrostatic and van der Waals forces. Negative charges within layers can be generated through isomorphic substitution, while there is also substitution between positive ions and organic or inorganic cations (Drummy et al., 2010; Garrido-Ramírez et al., 2010; Goettler et al., 2007). 
Table 2-1. Classification of clay minerals based on the layer type and charge per formula unit (Soleimani and Amini, 2017)

\begin{tabular}{|c|c|c|c|}
\hline $\begin{array}{l}\text { Layer } \\
\text { Type }\end{array}$ & Group & Subgroup & Species \\
\hline \multirow[t]{2}{*}{$1: 1$} & \multirow[t]{2}{*}{$\begin{array}{l}\text { Kaolin-serpentine } \\
\mathrm{x}=0\end{array}$} & Kaolin & $\begin{array}{l}\text { Kaolin, dickite, nacrite, } \\
\text { halloysite }\end{array}$ \\
\hline & & Serpentine & $\begin{array}{l}\text { Chrysotile, lizardite, } \\
\text { amesite }\end{array}$ \\
\hline \multirow[t]{13}{*}{$2: 1$} & \multirow{4}{*}{$\begin{array}{l}\text { Pyrophyllite-talc } \\
x=0 \\
\text { Smectite } \\
x=0.2-0.6\end{array}$} & Pyrophyllite & Pyrophyllite \\
\hline & & Talc & Talc \\
\hline & & $\begin{array}{l}\text { Montmorillonite } \\
\text { (tioctahedral smectite) }\end{array}$ & $\begin{array}{l}\text { Montmorillonite, } \\
\text { beidellite, nontronite }\end{array}$ \\
\hline & & $\begin{array}{l}\text { Saponite (trioctahedral } \\
\text { smectite) }\end{array}$ & Saponite, hectorite \\
\hline & \multirow{3}{*}{$\begin{array}{l}\text { Vermiculite } \\
x=0.6-0.9 \\
\text { Mica } x=0.5-1.0\end{array}$} & $\begin{array}{l}\text { dioctahedral vermiculite } \\
\text { trioctahedral vermiculite }\end{array}$ & $\begin{array}{l}\text { dioctahedral vermiculite } \\
\text { trioctahedral vermiculite }\end{array}$ \\
\hline & & dioctahedral mica & $\begin{array}{l}\text { Muscovite, illite, glauco- } \\
\text { nite, paragonite }\end{array}$ \\
\hline & & trioctahedral mica & $\begin{array}{l}\text { Phlogopite, biotite, } \\
\text { lepidolite }\end{array}$ \\
\hline & \multirow{2}{*}{$\begin{array}{l}\text { Brittle mica } x= \\
2.0\end{array}$} & dioctahedral brittle mica & Margarite \\
\hline & & trioctahedral brittle mica & Clintonite, anandite \\
\hline & \multirow{3}{*}{$\begin{array}{l}\text { Chlorite } \\
\mathrm{x}=\text { variable }\end{array}$} & dioctahedral chlorite & Donbassite \\
\hline & & di- tri-octahedral chlorite & Cookeite, sudoite \\
\hline & & trioctahedral chlorite & $\begin{array}{l}\text { Clinochlore, chamosite, } \\
\text { nimite }\end{array}$ \\
\hline & $\begin{array}{l}\text { Palygorskite- } \\
\text { sepiolite } \\
\mathrm{x}=\text { variable }\end{array}$ & $\begin{array}{l}\text { Sepiolite } \\
\text { Palygorskite }\end{array}$ & $\begin{array}{l}\text { Sepiolite } \\
\text { Palygorskite }\end{array}$ \\
\hline
\end{tabular}

$\mathrm{x}$ : charge per formula unit

\subsection{Surface properties}


Clay minerals have small particle size and large specific surface area, and high porosity (Yuan and $\mathrm{Wu}, 2007$ ). The existence of negatively charged surfaces in clay minerals is an important factor with respect to the CEC and swelling properties of the minerals. The charge in clay minerals is a function of their surface and structure characteristics. The surface charge usually depends on the value of the environmental $\mathrm{pH}$, while the structural charge originates in the interior of the layers and is permanent (due to ion exchange during crystal formation). In clay minerals of the 2:1layer type, the surface charge comes from the fundamental surface of the tetrahedral sheets. In clay minerals with a 1:1 layer, meanwhile, a surface charge comes from both the tetrahedral and the octahedral sheets, while the surface charge in two-type clays (1:1 and 2:1) comes from the edges of the sheets. The most important characteristic of clay minerals is CEC, which, in turn, is influenced by the total layer charge. Since the surface layer charge is affected by the $\mathrm{pH}, \mathrm{CEC}$ is typically measured at a neutral $\mathrm{pH}$ (Eslinger and Pevear, 1988). It should also be noted that, while ions and water molecules can be sobbed into the space between the sheets of 2:1 clay minerals, this is hard in 1:1 minerals, since the sheets are strongly bonded together and there is no free space.

\subsection{Use of nanoclays in industrial processes}

Use of nanoclays is increasing due to the fact that nanoclays' particular physicochemical properties lend themselves to a range of industrial applications (Njuguna et al., 2014). For instance, novel applications of advanced polymer/nanoclay composites have emerged in recent years due to their superior engineering properties, such as low density, high damping, high specific strength and stiffness, high fatigue endurance, and enhanced thermal behavior (Gürses, 2016). Approximately $75 \%$ to $80 \%$ of the applications of polymer/nanoclay composites have been in the automotive, aeronautical, and packaging industries. Many efforts have been made on polymer/nanoclay composite materials. Various types of nanoclays have been used in various fields, including rheology modification, food industries, biomedical industry, agriculture, animal feed, as well as environment remediation (Choy et al., 2007; Newman and Cragg, 2007). 


\subsubsection{Use as rheological control agent}

Nanoclays and their composite can be implemented in different industries. They can be used in asphalt mixture which can improve some inherit properties of asphalt such as increasing the rutting and fatigue resistance of asphalt mixtures and improving the storage stability and the aging resistance. It was reported that the strength and cracking resistance of asphalt mixture were improved when bentonite nanoclays were added into the mixture (Yang and Tighe, 2013). There is an important connection between the rheology of polymer/nanoclay composites and production of advanced materials with different applications. The main problem of petroleum-based polymers is related to their surface energy difference with nanoclays which make them to become incompatible with nanoclays. To overcome this problem, surfactants have been used recently. Nanoclay incorporated with surfactants was used in $\mathrm{CO}_{2}$ foam as stabilizer (Guo and Aryana, 2016). Due to enhancement in stability of formability of $\mathrm{CO}_{2}$ foam, oil recovery from a homogeneous porous medium in a microfluidic device was increased.

\subsubsection{Use in food packaging}

Due to the thermal and optimal properties of nanoclays, they have been used in food packaging industry. Nanoclays can act as a barrier to block various gases such as oxygen, carbon dioxide, water vapors and volatile compounds (flavors and taints) to spread in the air (Gürses, 2016). For instance, nanoclays were used to block ethylene vinyl alcohol $(\mathrm{EVOH})$ to develop durable packaging material (Leodopoulos et al., 2015). In another study, an antimicrobial food packaging material with intercalated structures was developed using poly caprolactone (PCL) nanoclay composite (Yahiaoui et al., 2014). Behroozi and Pakizeh (2017) reported a mixed membrane using poly(ether-b-amide)/MMT nanoclay composites for decreasing the $\mathrm{CO}_{2}$ permeation and increasing the permselectivity of $\mathrm{CO}_{2} / \mathrm{CH}_{4}$ and $\mathrm{CO}_{2} / \mathrm{H}_{2}$ at different pressures and clay loadings. The permeation of soluble $\mathrm{CO}_{2}$ gas was reduced by $28 \%$ for the highest clay loading and the $\mathrm{CO}_{2} / \mathrm{CH}_{4}$ selectivity was improved to 9 at $6 \mathrm{wt} \%$ clay loading at all pressures. 


\subsubsection{Use in biomedical applications and drug delivery}

The characteristics of polymer/nanoclay composites such as appropriate swelling, rheological properties, high retention capacities, large surface-area-to-volume ratio and affinity for biopolymers are suitable for some biomedical applications, such as tissue engineering, gene therapy, biosensing, bioimaging, and drug delivery (Wang et al., 2017). The composites of polymer/nanoclay were used in several studies for cell-transplantation applications in neural tissue engineering, and there were good results in terms of porosity, biocompatibility, and biodegradability (Fradique et al., 2016; Serrano et al., 2014). In another research concerning the biosensor, Kong et al. (2014) reported a glucose detector in human blood which was able to measure the glucose using a graphene/PANI/AuNPs/ glucose oxidase enzyme (GOx) modified screen-printed carbon electrode (SPCE). Fig. 23 presents the interaction of drugs with clay nanomaterials. Since the montmorillonite surface layers are negatively charged, they can interact with positively charged drugs through ion exchange procedure (Fig. 2-3a). The montmorillonite modified by aminopropyl silane shows the enhanced interfacial interaction which can facilitate the loading of negatively charged drugs like telmisartan and flurbiprofen (Fig. 2-3b). Depending on the structure of Halloysite nanoclay, drugs could be incorporated into the tubular pore through capillary condensation (Fig. 2-3c) (Khatoon et al., 2020). 


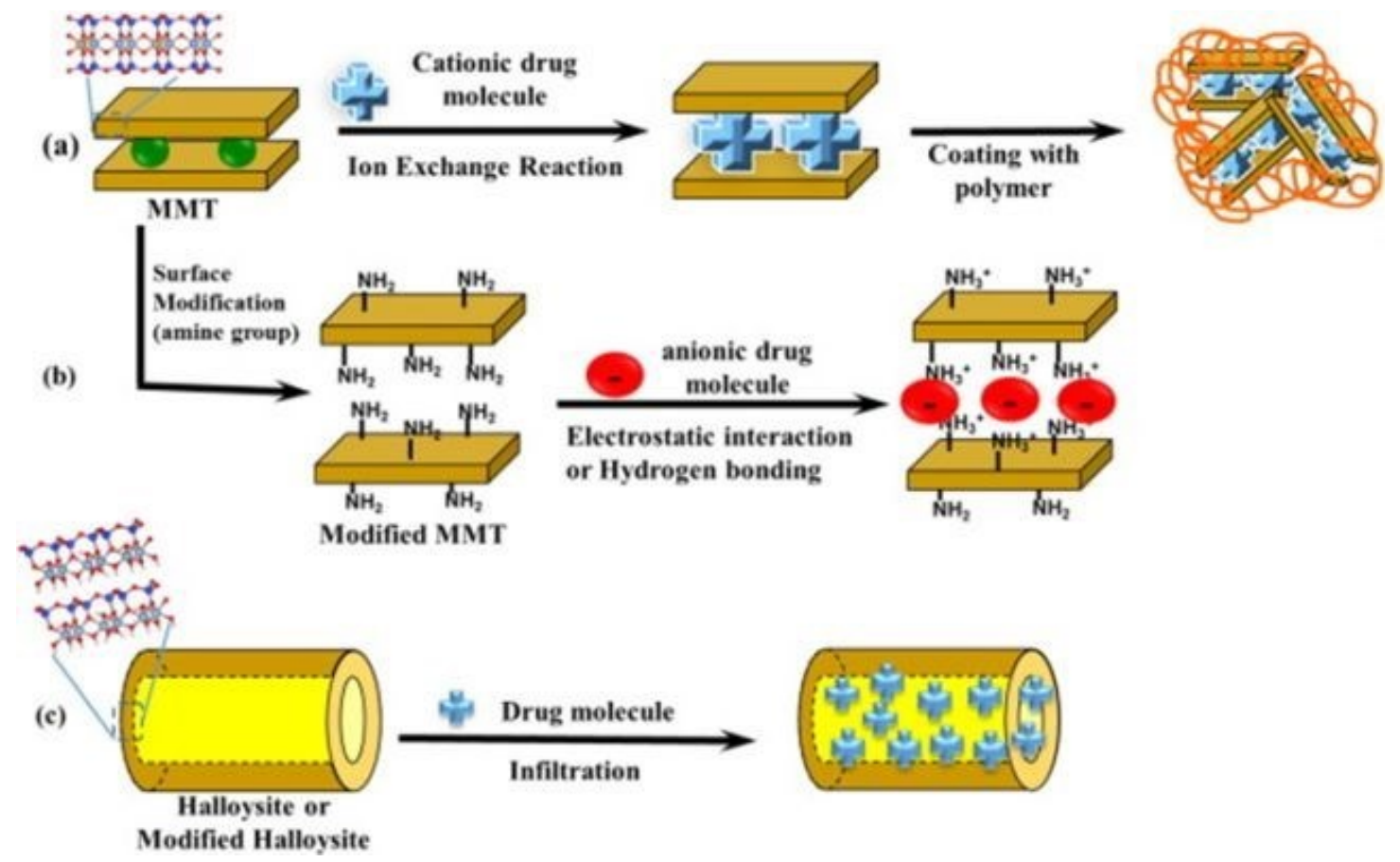

Figure 2-3. Interaction of montmorillonit (MMT) and halloysite with drug (Khatoon et al., 2020)

\subsection{Applications of nanoclays in pollutant removal from water}

There is growing concern about pollutants and their effects on the environment (Liu et al., 2021; Shrestha and Wang, 2020; Zhao et al., 2019a; Zhu et al., 2020). Nanoclays have been widely used as adsorbents due to their special characteristics. Nanoclays have advantages including their relatively low cost, high abundance, non-toxicity, and good adsorption properties (Uddin, 2017). Some of the basic factors are required for the proper functioning of nano-adsorbent are high surface area, and location of atoms on the surface. High potential of adsorption and high surface binding energy require surface attachment, inner side attachment, and edge attachment (Fig. 2-4) (Awasthi et al., 2019). The major applications of nanoclays in pollutant removal from water are for the removal of pharmaceutical compounds, dyes, heavy metals, pesticides and inorganic compounds from water. 


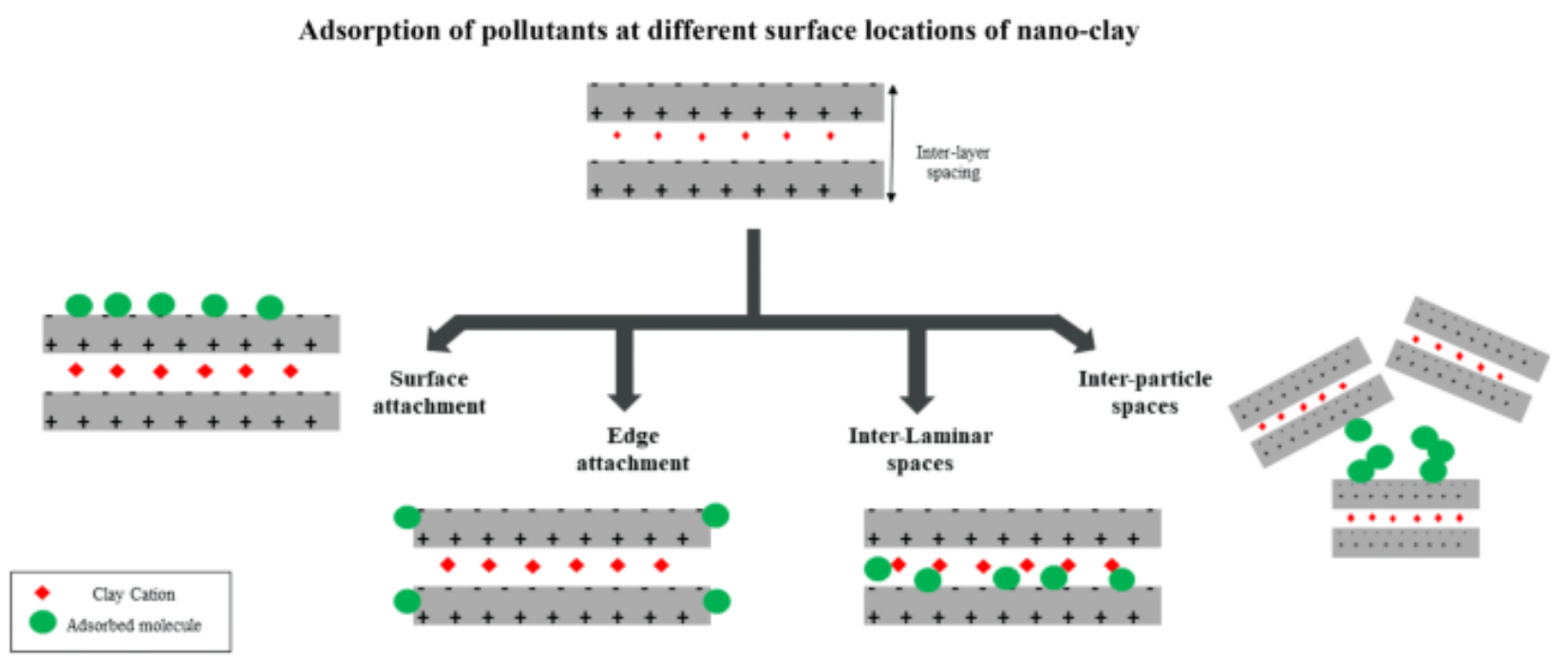

Figure 2-4. Adsorption of pollutants at the different surface locations of nano-clay

(Awasthi et al., 2019)

\subsubsection{Removal of pharmaceutical compounds from water}

The release of pharmaceutical compounds into the environment may pose a number of risks (Xin et al., 2020, 2019). In this context, numerous studies have been conducted to investigate the potential application of nanoclays as adsorbents in removing pollutants from water. For instance, Rafati et al. (2018) investigated the removal of ibuprofen from aqueous solution using nanoclay composite functionalized by mono-tosyl b-cyclodextrin (b-CD) solution. The X-Ray Diffraction (XRD) results demonstrated that, in the synthesized adsorbent, the distance between the clay layers was increased to $3.04 \mathrm{~nm}$ due to the interaction of polyvinylpyrrolidone (PVP) between the clay layers. In this case, the uptake was rapid, and the equilibrium was reached at $120 \mathrm{~min}$. The effect of $\mathrm{pH}$ was tested at the initial concentration of ibuprofen $3 \mathrm{mg} \mathrm{L}^{-1}$, initial amount of adsorbent $0.01 \mathrm{~g}$, and a contact time $120 \mathrm{~min}$. The results showed that increasing the $\mathrm{pH}$ had a negative impact on the adsorption process. Based on another test condition, the removal efficiency was found to increase by almost $50 \%$ when the contact time was increased from 5 to $120 \mathrm{~min}$. The maximum adsorption capacity was found to be $1.1 \mathrm{mg} \mathrm{g}^{-1}$, with a $\mathrm{pH}$ of 6 and $120 \mathrm{~min}$ of contact time(Rafati et al., 2018)(Rafati et al., 2018)(Rafati et al., 2018)(Rafati et al., 2018). 
More recently, Ramanayaka et al. (2020) studied the application of halloysite nanoclay in the removal of oxytetraycline (OTC) antibiotic from water. They studied the effect of $\mathrm{pH}$ on adsorption in constant conditions: an initial OTC concentration of $25 \mathrm{mg} \mathrm{L}^{-1}$, an adsorbent dosage of $1 \mathrm{~g} \mathrm{~L}^{-1}$, and the removal temperature set at room temperature. Their results confirmed that OTC adsorption was $\mathrm{pH}$-dependent, with increasing $\mathrm{pH}$ from 3 to 8 corresponding to a decrease in removal efficiency. The highest removal efficiency, $68 \%$, was achieved at a $\mathrm{pH}$ of 3 .

Rafati et al. (2016) studied the optimum conditions for the removal of naproxen from water using a novel modified nanoclay. In their study, the nanoclay was prepared by first modifying it with $\beta$-cyclodextrin and then polymerizing it using PVP to provide more surfaces and thus achieve higher adsorption. The effects of $\mathrm{pH}$ and adsorbent dosage in the system were observed. At room temperature, it was determined that increasing the $\mathrm{pH}$ from 5 to 6 caused an increase in the adsorption, while continuous increase from 6 to 9 decreased the uptake amount. They observed that, at $\mathrm{pH} 6$, approximately $90 \%$ of contaminants were removed from the system. To understand how the adsorbent dosage in the system could affect the process, at $\mathrm{pH} 6$ and with a constant initial concentration of naproxen, the adsorbent dosage was increased from 0.125 to $1 \mathrm{~g} \mathrm{~L}^{-1}$, resulting in an increase in the removal efficiency from $78.4 \%$ to $92.2 \%$. This finding was attributed to two factors. First, increasing the adsorbent dosage raises the likelihood of collisions between adsorbent and adsorbate. Second, in a system with a high adsorbent dosage, the effect of the boundary layer around the adsorbent (kinetics limitation factor) is reduced. The optimum values for adsorbent dosage, contact time, initial naproxen concentration, and $\mathrm{pH}$ were found to be 1 $\mathrm{g}, 120 \mathrm{~min}, 10 \mathrm{mg} \mathrm{L}^{-1}$, and 6, respectively.

\subsubsection{Removal of dyes from water}

The discharge of dye-bearing wastewater into natural streams and rivers from the textile, paper, carpet, leather, distillery, and printing industries results in severe problems, such as aquatic life being exposed to toxins, and damage to the natural beauty of the environment 
(Wang et al., 2018; Zhang et al., 2017). As such, there is a considerable need for solutions to facilitate the removal of these dyes from wastewater/effluents. Many methods such as aerobic and anaerobic microbial degradation, coagulation, chemical oxidation, membrane separation, and electrochemical treatment have been used to eliminate dye from the water and wastewater. Most dyes used in industries are stable and hard to be removed in treatment (Coro and Laha, 2001). Although different elimination methods have been suggested, they usually have some limitations. Removal of color/dye by adsorption is an alternative in treatment.

Various industrial dyes have been deployed experimentally to assess the efficacy of nanoclay as an adsorbent. Azha et al. (2017) studied the removal of Brilliant Green (BG)with Bentonite-modified composite. The adsorbent was prepared using a simple solgel method in which acrylic polymer emulsion (APE) and bentonite on cotton cellulosic fiber $(\mathrm{CCF})$ were mixed together. Under constant conditions, the removal efficiency of dye was found to increase along with the bentonite content. In addition, a coating of acrylic polymer emulsion (APE) and bentonite on the cotton cellulosic fiber (CCF) showed promising results, achieving a dye removal efficiency of approximately $80 \%$. The results demonstrated that increasing the initial concentration of dye resulted in an elevated maximum adsorption capacity. The results also showed that increasing the temperature could increase the removal efficiency. The maximum adsorption capacity was observed at $52.63 \mathrm{mg} \mathrm{g}^{-1}$, this having been achieved at a temperature of $70{ }^{\circ} \mathrm{C}$.

El Haouti et al. (2019) studied the adsorption isotherm and kinetic behavior of two cationic dyes, Toluidine Blue (TB) and Crystal Violet (CV), on a Na-montmorillonite nanoclay. The effect of the adsorbent dosage on the process was examined under constant conditions. They reported that increasing the adsorbent dosage from 0.1 to $1.2 \mathrm{~g} \mathrm{~L}^{-1}$ resulted in an increase in the removal efficiency of the two dyes from $76 \%$ to $99.61 \%$ for $\mathrm{CV}$ and from $82 \%$ to $99.66 \%$ for TB. They found that the Langmuir isotherm predicted the adsorption results well, while the pseudo-second-order model described accurately the adsorption kinetics. The maximum adsorption for both dyes occurred at a $\mathrm{pH}$ of 11 , while the maximum adsorption capacity for TB was $5.8 \mathrm{mmol} \mathrm{g}^{-1}$, and the same for $\mathrm{CV}$ was 5.40 
$\mathrm{mmol} \mathrm{g}^{-1}$. The effect of changing $\mathrm{pH}$ on the adsorption process was also examined. They found that the removal efficiency for CV dye and TB dye increased from $50 \%$ to $99 \%$ and from $38 \%$ to $98 \%$, respectively, as the $\mathrm{pH}$ of the solution was increased from 4 to 11 .

Shirsath et al. (2011) studied the feasibility of adsorption in removing dye pollutants using synthesized nanoclay. In their study, the poly (acrylic acid)-bentonite-FeCo nanocomposite hybrid hydrogel was synthesized in a polymerization process incorporated with ultrasound. The effect of $\mathrm{pH}$ was evaluated under an initial adsorbate concentration of $30 \mathrm{mg} \mathrm{L}^{-1}$ and $1 \mathrm{~g}$ of adsorbent. Their results showed that the maximum adsorption occurred when the $\mathrm{pH}$ was increased from 9 to 11, and they attributed this to the existence of $\mathrm{COOH}$ functional groups in the adsorbent that dissociated in that range of $\mathrm{pH}$. Based on the applied temperature tests, temperature was found to positively influence the adsorption process. Increasing the dye concentration from 20 to $50 \mathrm{mg} \mathrm{L}^{-1}$, meanwhile, resulted in an increase in the adsorption rate. The combination of hydrogel and ultrasound resulted in more uptake ( $97 \%$ removal was obtained in $5 \mathrm{hr}$ ). They also noted that the maximum adsorption capacity for synthesized nanoclay was $13 \mathrm{mg} \mathrm{g}^{-1}$, this having been obtained at $35^{\circ} \mathrm{C}$ and a $\mathrm{pH}$ of 11. Sonawane et al. (2009) synthesized a novel PAA-nanoclay nanocomposite from bentonite in cetyltrimethylammonium bromide (CTAB) solution assisted with ultrasound. To analyze how an increase in adsorption might affect the process, experiments were carried out with a constant temperature of $30^{\circ} \mathrm{C}, 0.5 \mathrm{~g}$ of adsorbent, and $500 \mathrm{mg} \mathrm{L}^{-1}$ initial concentration of malachite green dye. The results demonstrated that more uptake occured when the $\mathrm{pH}$ in the system was increased (from 4 to 12 in this case) since, at a higher $\mathrm{pH}$, the surface of the adsorbent became less positive and attracted more dye molecules to be adsorbed. The Freundlich model described the data well, signifying the occurrence of multilayer adsorption.

Salam et al. (2017) conducted a study to investigate the application of different nanoclays in removing Orange $\mathrm{G}(\mathrm{OG})$ dye from water. Different adsorbents were selected, including hydrophilic bentonite nanoclay (BN nanoclay), surface-modified montmorillonite nanoclay containing trimethyl stearyl ammonium (TMS nanoclay), surface-modified montmorillonite nanoclay containing octadecylamine (ODA nanoclay), surface-modified 
montmorillonite nanoclay containing methyl dihydroxyethyl hydrogenated tallow ammonium (MDH nanoclay), and Halloysite Nanoclay (HS nanoclay). The results showed ODA nanoclay to be the most efficient absorbent with the removal of $98 \%$ Approximately. The results under different experimental conditions confirmed that increasing the adsorbent dosage can increase the adsorption capacity, although further increases beyond a certain threshold do not have a significant effect on the adsorbent capacity. They observed that the removal efficiency increased by almost $13 \%$ when the $\mathrm{pH}$ was raised from 2 to 4 . Increasing the temperature in the system also resulted in an increase in adsorption (by almost 40\%). In another study by Ali (2019), graphene nanosheets were prepared from graphite-nanoclay composite using electrochemical exfoliation. The synthesized adsorbent was then tested to remove methyl blue (MB) and methyl orange (MG) from water at a neutral $\mathrm{pH}$. With an absorbent dosage of $1 \mathrm{~g} \mathrm{~L}^{-1}$ in the system, the removal efficiencies obtained for MB and MG were $77 \%$ and $22 \%$, respectively.

\subsubsection{Removal of heavy metals from water}

One of the growing environmental concerns in the developing world is heavy metal contamination. Inadequate water and wastewater treatment, coupled with increased industrial activity, have led to increased heavy metal contamination in water sources around the world. To address these concerns, common methods for removing heavy metals from water sources, including membrane filtration, activated carbon adsorption, and electrocoagulation have been used for removing heavy metals from water (Joseph et al., 2019). For instance, a novel nanocomposite was implemented to investigate the removal of $\mathrm{Pb}$ (II) from water (Matei et al., 2020). This nanocomposite was synthesized by mixing sodium alginate, nanoclay $\left(\mathrm{H}_{2} \mathrm{Al}_{2} \mathrm{O}_{6} \mathrm{Si}\right)$, Microcrystalline cellulose, and Calcium chloride. The authors of this study found that $1 \mathrm{~g}$ of adsorbent could remove $60 \%$ of $4 \mathrm{mg} \mathrm{L}^{-1}$ initial concentration of lead in $15 \mathrm{~min}$. After 90 minutes, the removal efficiency increased to $90 \%$. The results also showed that a maximum adsorption capacity of $0.11 \mathrm{mg} \mathrm{g}^{-1}$ was achieved.

Bandpei et al. (2017) investigated the potential application of modified montmorillonite 
clay (hexadecyltrimethyl ammonium chloride) to remove arsenic from water. They found that changing the $\mathrm{pH}$ and initial arsenic concentration did not affect the adsorption process. The optimum conditions for removal were found to be at $37.2 \mathrm{~min}$ with $3.7 \mathrm{~g} \mathrm{~L}^{-1}$ adsorbent dosage. Under these conditions it was found that an arsenic removal efficiency of $95.5 \%$ was achieved.

Both natural and modified forms of clay minerals have excellent feasibility in removing different toxic aquatic metal pollutants. However, modification and further development of the clay materials despite of the expensive procedures, can enhance pollution control. (Fig. 2-5)

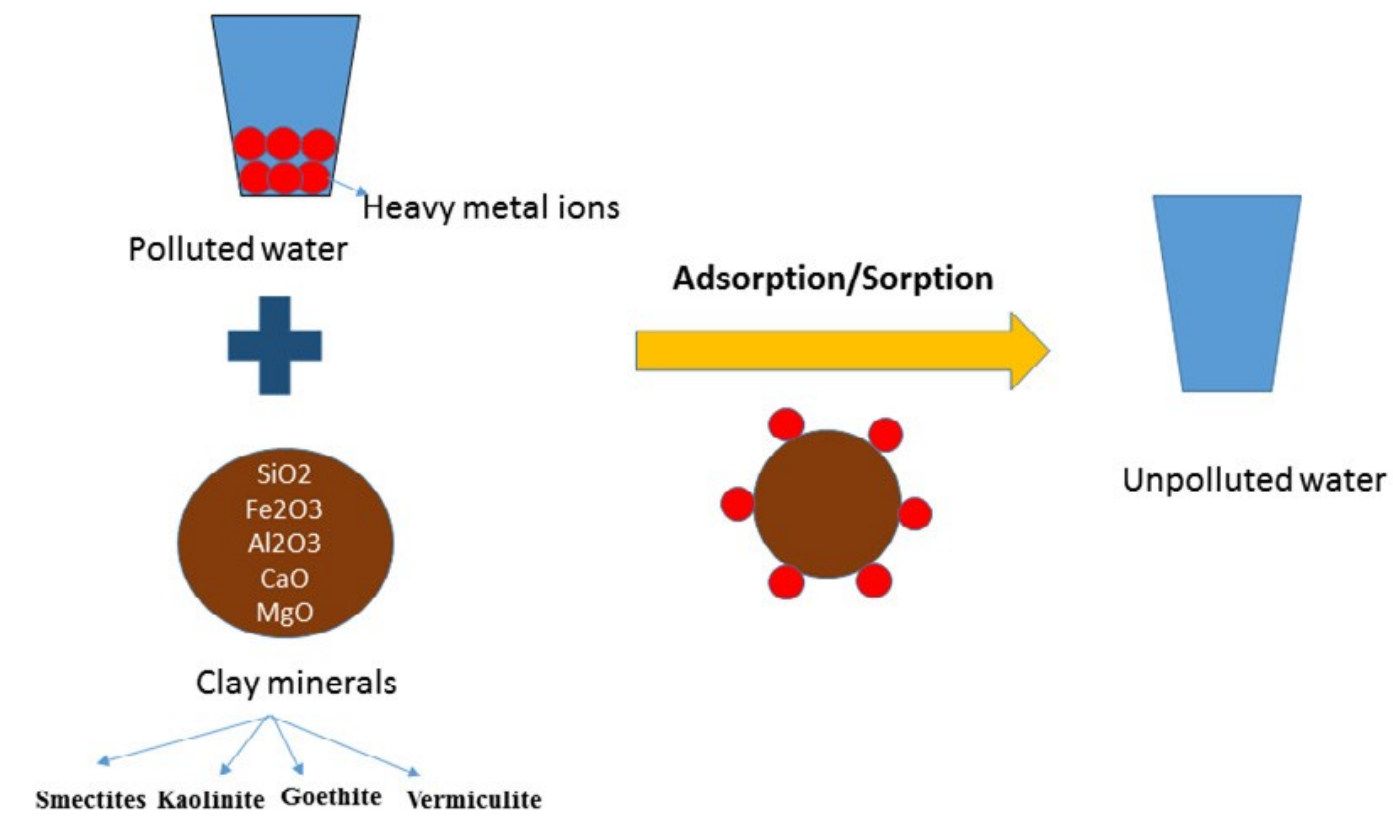

Figure 2-5. Removal of heavy metals from water using nanoclays (Uddin, 2017)

\subsubsection{Removal of pesticides from water}

Pesticides are a group of artificially synthesized substances used to fight pests and improve agricultural production. They are, however, generally toxic for living organisms and are 
difficult to degrade, being toxic agents with persistent bioaccumulative effects (Ormad et al., 2008). The frequent detection and removal of pesticides in water sources is of great concern to the public, to authorities and all those involved in potable water production, water/wastewater treatment and reuse, due to potentially adverse health effects associated with these compounds, even at very small concentrations (Plakas and Karabelas, 2012). Nanoclays can be used in removing pesticides. Shabeer et al. (2015) investigated the efficiency of coagulation method coupled with adsorption in removing multi pesticides. Different nanoclays including nano-bentonite, and organically modified nanomontmorillonite were used. The results obtained from just adsorption with nanoclays, among used nanoclays, the removal efficiency for organically modified nanomontmorillonite was between 60.1 and $77 \%$ for different pesticide, while for nanobentonite was varied between 51.7 and $69.3 \%$. Also, the removal was studied through adsorption incorporated with coagulation method. The results confirmed that coagulation with alum could increase removal percentage to $75.1 \%$ (for removal with nano-bentonite) and to $92.5 \%$ (for removal with montmorillonite).

Siboni et al. (2015) studied the application of surfactant-modified pillared montmorillonites (MMT) in removal of bentazon from the water. The adsorbent was prepared through intercalation method in which 1 gr of MMT was dispersed in water and stirred for $4 \mathrm{hr}$, then specific amount of Cetyltrimethylammonium bromide was added into solution and stirred for $5 \mathrm{hr}$. After that, solution was filtered and washed and wet adsorbent was dried at $90^{\circ} \mathrm{C}$ in the oven for $24 \mathrm{hr}$. Effects of operational parameters on the adsorption performance were examined. Effect of adsorbent dosage on the adsorption capacity was studied at constant condition in which $\mathrm{pH}=7$, ambient temperature, contact time $=90 \mathrm{~min}$, and initial concentration $=20 \mathrm{mg} \mathrm{L}^{-1}$. It was observed that increasing adsorbent dosage in the system from 0.05 to $0.5 \mathrm{~g} \mathrm{~L}^{-1}$ the removal efficiency was increased from 10 to $90 \%$. Effects of contact time also was investigated under constant condition $(\mathrm{pH}=7$, ambient temperature, adsorbent dosage $=0.5 \mathrm{~g} \mathrm{~L}^{-1}$, and initial concentration $=20 \mathrm{mg} \mathrm{L}^{-1}$ ). The result 
confirmed that the rapid adsorption was occurred in the first stage of contact while after that the adsorption became slow and after 90 min the system was at equilibrium state. Effect of $\mathrm{pH}$ as an operational parameter on the adsorption capacity was also considered. The experiment was carried out at ambient temperature, contact time $=90 \mathrm{~min}$, initial concentration $=20 \mathrm{mg} \mathrm{L}^{-1}$, and adsorbent dosage $=0.5 \mathrm{~g} \mathrm{~L}^{-1}$. The results demonstrated that increasing $\mathrm{pH}$ from 3 to 11 could affect the removal efficiency negatively. According to author, the removal efficiency was $99 \%$ at $\mathrm{pH}=3$ while this number was decreased to $35 \%$ at $\mathrm{pH}=11$. Furthermore, the photocatalyst degradation of phenol in acoustic cavitation was carried out using $\mathrm{TiO}_{2}$-nanoclay. $\mathrm{TiO}_{2}$-nanoclay nanocomposite was developed in benzyl alcohol medium. The TEM images demonstrated that $\mathrm{TiO}_{2}$ particles were formed between nanoclay platelets and the synthesized nanocomposite particle sizes were in range of 30$40 \mathrm{~nm}$. For one hour degradation of $500 \mathrm{ppm}$ initial concentration of phenol with $0.75 \mathrm{~g}$ loading of nanocomposite, it was noticed that the removal efficiency would be $60 \%$ and this number could increase by increasing the nanocomposite loading (Ghodke et al., 2012).

\subsubsection{Removal of inorganic compounds from water}

Water contamination by inorganic compounds is a ubiquitous problem, requiring their removal to meet stringent water quality standards (Fan et al., 2020; Jeswani et al., 2015; Yang et al., 2021). A number of inorganic compounds, including anions such as nitrate(V), chlorate (VII), bromate(V), arsenate (III) and (V), borate and fluoride as well as metals forming anions under certain conditions, have been found in potentially harmful concentrations in numerous water sources (Crespo et al., 2004; Konieczny and Bodzek, 2007; Velizarov s., 2008, 2004). Some of these compounds are highly soluble in water and dissociate completely, resulting in ions that are chemically stable under normal water conditions (Bodzek and Konieczny, 2011). The efficiency of removal of these contaminants varies significantly, and depends on the water or wastewater treatment method [76],[77]. Current technologies for water treatment include coagulation/flocculation/sedimentation, 
activated carbon, carbon nanotubes, chlorination, ozonation, biodegradation, membrane filtration, sono-degradation and ultraviolet light (Chu et al., 2017; Kim et al., 2018a; Park et al. 2017a, 2017b). Of all these common technologies, adsorption is generally recognized as the most promising technique for water and wastewater treatment due to its adaptability, wide applicability, cost-effectiveness and feasibility (Chowdhury and Balasubramanian, 2014). In particular, activated carbon (i.e., a crude form of graphite) is the most favored adsorbent owing to its large effective surface area and highly porous structure (Kim et al., 2018; Malaviya and Singh, 2011; Mohanadhas and Govindarajan, 2018; Yeom and Kim, 2017).

Also, to study the removal of sulfate in aqueous solutions, a novel adsorbent was synthesized by Chen et al. (2014) The organo-nanoclay was prepared by natural zeolite and cationic surfactant cetyltrimethylammonium bromide (CTAB). To study effects of adsorbent dosage, the experiment was carried out under constant condition $(\mathrm{pH}=7$, contact time $=2 \mathrm{hr}$, temperature $=40{ }^{\circ} \mathrm{C}$ and initial concentration $500 \mathrm{mg} \mathrm{L}^{-1}$ ). The results demonstrated that increasing adsorbent dosage from 0.5 to $5 \mathrm{~g}$ led to more uptake. According to authors, removal efficiency was $80.4 \%$ for $2 \mathrm{~g}$ adsorbent in the system and adding more adsorbent in the system could slightly increase the removal percentage. To find the optimum contact time, the experiment was carried out with condition of $\mathrm{pH}=7$, temperature $=40{ }^{\circ} \mathrm{C}$, initial concentration $500 \mathrm{mg} \mathrm{L}^{-1}$ and adsorbent dosage $=2 \mathrm{~g} \mathrm{~L}^{-1}$. The results depicted that the system reached equilibrium condition at 2 hour and after that no more contaminant was adsorbed by the adsorbent. Also, effect of temperature was studied. The experiment was done at the constant condition including $\mathrm{pH}=7$, contact time $=2 \mathrm{hr}$, and initial concentration $500 \mathrm{mg} \mathrm{L}^{-1}$ and adsorbent dosage $2 \mathrm{~g} \mathrm{~L}^{-1}$. It was stated that the amount of adsorption was increased from $13 \mathrm{mg} \mathrm{g}^{-1}$ to $20.15 \mathrm{mg} \mathrm{g}^{-1}$ when temperature was elevated from 25 to $40{ }^{\circ} \mathrm{C}$. However, further increase in the temperature did not change the amount of adsorption. The maximum adsorption capacity was determined to be $38.02 \mathrm{mg}$ $\mathrm{g}^{-1}$ at $40{ }^{\circ} \mathrm{C}$. 
Almasri et al. (2018) studied removal of arsenic from the water using hydroxyiron modified montmorillonite. To prepare the adsorbent, first the montmorillonite nanoclay solution in the water was prepared and then specific amount of $\mathrm{FeCl}_{3} \cdot 6 \mathrm{H}_{2} \mathrm{O}$ was dispersed in the solution and stirred. The final wet nanoclay was dried in the oven. Effect of operating conditions on the adsorption performance was analyzed. The effect of adsorbent dosage was studied at neutral $\mathrm{pH}$ and room temperature. The results confirmed that untreated montmorillonite nanoclay was unable to remove arsenic while treated montmorillonite with Fe could remove arsenic from the solution. Increasing adsorbent dosage for treated montmorillonite from 20 to $80 \mathrm{mg}$ increased the removal efficiency from 20 to $90 \%$. However, further increase in the adsorbent dosage did not have significant effect on the removal. Effect of contact time on the adsorption performance was another parameter which was studied. According to authors, at $\mathrm{pH}=3$, adsorbent dosage $=80 \mathrm{mg}$, arsenic initial concentration $=1 \mathrm{mg} \mathrm{L}^{-1}$ and shaking speed $=350 \mathrm{rpm}$, increasing contact time from 1 to 20 min could increase removal efficiency from 55 to $80 \%$. However, further increase in contact time did not have any effects on adsorption performance. According to authors, the adsorption was $\mathrm{pH}$ dependent. At arsenic initial concentration $=1 \mathrm{mg} \mathrm{L}^{-1}$, adsorbent dosage $=$ $80 \mathrm{mg}$, contact time $=2 \mathrm{hr}$, increasing $\mathrm{pH}$ from 3 to 9 could enhance removal percentage from 77\% to 90\%(Almasri et al., 2018)(Almasri et al., 2018)(Almasri et al., 2018)(Almasri et al., 2018)(Almasri et al., 2018).

Sometimes, nanoclays can be used in membrane systems. For examples, a study was conducted to investigate the potential application of nanoclay in microfiltration membrane to remove organic pollutant from aqueous solutions. The novel nanoclay membrane was synthesized through mixing clay, zeolite and polyethylene glycol at $900{ }^{\circ} \mathrm{C}$. Zeolite was used to increase the porosity and it was determined that the highest porosity for the membrane was $30.2 \%$ which obtained with $30 \mathrm{wt} \%$ of zeolites in the mixture. Three different dyes were used including crystal violet, methylene blue, and methyl orange. It was demonstrated that $95.55 \%$ removal of crystal violet was obtained for the $54 \mathrm{mg} \mathrm{L}-1$ solution at 1 bar and $90.23 \%$ removal of methylene blue was obtained at optimal conditions with a $35.76 \mathrm{mg} \mathrm{L}^{-1}$ concentration and 1.5 bar pressure (Foorginezhad and Zerafat, 2017). 
Some studies have been carried out to analyze the physical modifications could be created after adding nanoclays into the composite materials. Asadi et al. investigated the surface modification of hollow polyester fiber using nano clay, nano $\mathrm{TiO}_{2}$ and polysiloxane. The EDX patterns and SEM images confirmed the presence of nanoparticles on the fabric surface. Further the presence of polysiloxane softener and resin led to the uniform distribution of nanoparticles with smaller size on the fabric surface. The XRD analysis proved the presence of nano clay and crystalline anatase titanium dioxide on the fabrics (Asadi and Montazer, 2013). In another research, a novel nanocomposite was developed and physical charecteristics were investigated. Nanocomposite was developed through mixing carbon nanotube and kaolinite. According to authors, both materials were treated and functionalized and then they were fabricated through solution method. Through high resolution transmission electron microscopy (HRTEM) analysis, the diameter of nanocomposite was determined $20 \mathrm{~nm}$. Also, mean sized of crystalline structure was evaluated $19.55 \mathrm{~nm}$ with X-ray diffraction. Also, Brunauer-Emmett-Teller (BET) analysis results demonstrated that surface area was $23.43 \mathrm{~m}^{2} \mathrm{~g}^{-1}$. Similarly, Langmuir surface area was $33.95 \mathrm{~m}^{2} \mathrm{~g}^{-1}$, and total pore volume was $0.10 \mathrm{~cm}^{3} \mathrm{~g}^{-1}$ (Yadav et al., 2018).

\subsection{Applications of nanoclays in gas emission control}

The main source of release of toxic gases into the atmosphere is industrial activities (Asif and Chen, 2020; Lerner et al., 2019). The reduction of gaseous pollutants, particularly volatile organic compounds, using thermal oxidation is expensive due to the need of high amount of energy. In this regard, more efficient processes combined with absorption techniques can be developed to improve the efficiency of catalytic oxidation and finally gas removal (Mestre et al., 2010). Many studies have shown the absorption of polar and non-polar gases and water vapor molecules by different types of nanoclay minerals, specially pillared nanoclays which have been widely developed for air pollutant abatement nowadays. Nanoclays can be interesting alternatives to reduce and finally remove gaseous pollutants due to having hydrophobic and hydrophilic properties. According to the wide 
use of nanoclays in control of gaseous pollutants, the researchers have improved sorption processes and control of gaseous pollutants using modified nanoclays.

\subsubsection{Applications in $\mathrm{H}_{2} \mathrm{~S}$ removal}

Problems associated with removal of odor from air have become controversial issues, especially in urban areas. One of the leading malodorants arising from sewage treatment facilities is hydrogen sulfide (Adib et al., 2000; Turk et al., 1989). H2S is produced by various industrial and natural activities, such as petroleum refining, methane-containing biogas production, wastewater treatment, and food processing (Hou et al., 2018; Hughes et al., 2009; Janssen et al., 2009; Storhaug, 1986). $\mathrm{H}_{2} \mathrm{~S}$ is malodorous at low levels and toxic at high levels, inhibiting aerobic respiration to humans and microorganisms (Nicholls and Kim, 1982). It can also be problematic in sewer systems, causing corrosion (Kabil and Banerjee, 2010; Zhang et al., 2008). Different types of adsorption methods such as fixed bed adsorption, pressure swing adsorption and sequential bed methods were experimentally used to investigate the removal of hydrogen sulfide (Ozekmekci et al., 2015).

Stepova et al. (2009) studied the possibility of $\mathrm{H}_{2} \mathrm{~S}$ removal using modified bentonite as the adsorbent. According to authors, the adsorbent was modified with iron and copper chlorides. The modified procedure had impact of surface area and it caused to increase from $26 \mathrm{~m}^{2} \mathrm{~g}^{-1}$ to $69 \mathrm{~m} 2 \mathrm{~g}-1$. The result of adsorption confirmed that the adsorbent had the ability to remove hydrogen sulfur and the capacity was $39.2 \mathrm{mg}$ g-1. In another study, Morozov et al. (2014) studied the sorption of volatile organic compounds (VOCs) such as n-hexane, benzene, and methanol on K-10 montmorillonite. The adsorption results of dried adsorbent (dried in oven at $250{ }^{\circ} \mathrm{C}$ ) showed that adsorbent could remove benzene and $\mathrm{n}$ hexane from the system and the amounts obtained at $\mathrm{P} / \mathrm{P} 0=0.4$ were 179 and $185 \mu \mathrm{g} \mathrm{L}^{-1}$ (Morozov et al., 2014). However, these numbers were decrease when the adsorbent dried 
at $105^{\circ} \mathrm{C}$ and had $8 \mathrm{wt} . \%$ water content. The sorption values were $160 \mu \mathrm{g} \mathrm{L}^{-1}$ for benzene and $169 \mu \mathrm{g} \mathrm{L}^{-1}$ for $\mathrm{n}$-hexane. According to authors, in tertiary system including $\mathrm{n}$-hexane, benzene, and methanol, the dried adsorbent could remove VOCs and the values of sorption were 179,185 , and $160 \mu \mathrm{g} \mathrm{L}^{-1}$ for benzene, n-hexane, and methanol respectively.

\subsubsection{Applications in $\mathrm{CO}_{2}$ capture}

$\mathrm{CO}_{2}$ has been considered as a critical factor in global warming. $\mathrm{CO}_{2}$ capture and storage has been identified as a practical procedure to reduce the amount of $\mathrm{CO}_{2}$ releases into the environment. Khajeh et al.(2020) explored the parameters affecting $\mathrm{CO}_{2}$ adsorption over the modified montmorillonite nanoclay and found the optimum adsorption condition. Two preparation procedures were applied to the adsorbent before using in the adsorption. First acid treatment and second modification with $\mathrm{NaOH}$. To complete the acid treatment, as a first step, different samples were prepared through adding nanoclays into water at $90{ }^{\circ} \mathrm{C}$. Then each sample was added into $10 \mathrm{~mL}$ solution of hydrochloric acid with selected concentration $(2,3,4,5$ and $6 \mathrm{M})$. The final suspension solution was stirred magnetically for $4 \mathrm{hr}$. After $4 \mathrm{hr}$, samples were filtered and washed with deionized water to reach $\mathrm{pH}$ between 4 and 5. Then, each sample was dried in the oven at $50{ }^{\circ} \mathrm{C}$ for $12 \mathrm{hr}$. After first drying, samples were crushed to convert them into powder and in the last step, they were dried in the oven at $100{ }^{\circ} \mathrm{C}$ for 24 hours. For immobilization of $\mathrm{NaOH}$ on the surface of nanoclay wet impregnation method was used. According to authors, the results of analysis of variance depicted that pressure, temperature, and $\mathrm{wt} \% \mathrm{NaOH}$ were selected as the most important parameters affecting the adsorption. Also, the optimum conditions were identified. According to authors, the optimum value for temperature was $65^{\circ} \mathrm{C}$, for pressure was 1.00 bar, for $\mathrm{HCL}$ concentration was $5.99 \mathrm{M}$ and $39.76 \%$ for $\mathrm{NaOH}$ which under this condition the adsorbent capacity was $105.55 \mathrm{mg}$. $\mathrm{g}^{-1}$.

Fu et al. (2017) investigated the potential application of aqueous adsorbent for $\mathrm{CO}_{2}$ capture. The experiments were operated at ambient conditions and amino-propyl magnesium phyllosilicate nanoparticles (aminoclay) was used as the adsorbent. The adsorbent was 
synthesized through co-condensation method in which magnesium chloride $(\mathrm{MgCl} 2)$ and 3-aminopropyltriethoxysilane were condensed in ethanol solution at ambient condition. The effect of $\mathrm{pH}$ on the adsorption was studied. It was confirmed that increasing $\mathrm{pH}$ from 6 to 12 , let to more adsorption capacity. According to authors, at $\mathrm{pH} 6$, the adsorbent capacity was $4.2 \mathrm{mmol} \mathrm{g}^{-1}$, while at $\mathrm{pH} 12$ this amount was increased into $9.4 \mathrm{mmol} \mathrm{g}^{-1}$. This enhancement was attributed into deprotonation of adsorbent at higher $\mathrm{pH}$ (Fu et al., 2017).

Ramadass et al. (2020) synthesized carbon nanoflakes and nanotubes from halloysite nanoclay and investigated its application in $\mathrm{CO}_{2}$ capture. The results from three investigated adsorbents halloysite nanoclay, halloysite nanoporous carbon (HNC) and activated halloysite nanoporous carbon (AHNC) demonstrated that halloysite nanoclay could not adsorb $\mathrm{CO}_{2}$ while the other two adsorbents had the ability to uptake $\mathrm{CO}_{2}$. Accordingly, AHNC showed approximately double capacity in regards of $\mathrm{CO}_{2}$ adsorption compared to HNC. Additionally, based on the results temperature had a negative impact on the $\mathrm{CO}_{2}$ capturing. Roth et al. (2013) conducted a study to capture $\mathrm{CO}_{2}$ using a low-cost adsorbent named montmorillonite nanoclay. The modified adsorbent for the experiments was prepared through two step procedures by using N-dimethylformamide (DMF), 3aminopropyltrimethoxysilane (APTMS) and Polyethylenimine (PEI). The results confirmed that untreated nanoclay was unable to adsorb $\mathrm{CO}_{2}$ while the treated adsorbent could remove $\mathrm{CO}_{2}$. The adsorption data depicted that at $50{ }^{\circ} \mathrm{C}$, removal percentage of untreated adsorbent was $1 \%$ while for the treated adsorbent was $4 \%$. In addition, based on the experiments, increasing temperature had positive effect on $\mathrm{CO}_{2}$ capturing. The highest removal percentage was happened at $85{ }^{\circ} \mathrm{C}$ which was $7.5 \%$. Furthermore, based on the results, $\mathrm{CO}_{2}$ pressure had also positive effect on adsorption capacity. The removal percentage of adsorbent was $8 \%$ at $690 \mathrm{kPa}$ while this number was $11.5 \%$ at $2070 \mathrm{kPa}$.

\subsection{Environmental toxicity of nanoclays}

It is no doubt that nanotechnology has a wide range of applications including clean energy, 
medicine, chemistry, physics, and so one (Naqvi et al., 2018). However, there has been a concern regarding nanomaterials. Nanotoxicology has drew scientists' attention when the relation between particle, chemical nature, and toxic effects were demonstrated. In 2005 , nanotoxicology was identified as a separate research field with the launch of Nanotoxicology journal (M. Roberto and A. Christofoletti, 2020)

\subsubsection{Toxicological evaluation methods}

Toxicological assessment plays a key role to prevent the potential negative effects of nanomaterials on humans and the environment (Rai and Biswas, 2019). Considering the size of nanoparticles, they have greater potential compared to other particle sizes to travel through living organisms' body. Before evaluation of nanomaterials toxicity, it is crucial to understand and analyze nanomaterials physical characteristics. Table 2-2 demonstrates physical properties required for toxicity evaluation (M. Roberto and A. Christofoletti, 2020).

Table 2-2. Analysis of nanomaterials properties required for toxicity evaluation (M.

Roberto and A. Christofoletti, 2020)

\begin{tabular}{ll}
\hline Properties & Relevance \\
\hline Particle size distribution & Essential \\
Degree/state of agglomeration & \\
Particle shape & Important \\
Chemical composition/purity & \\
Solubility & Essential \\
Density & $\begin{array}{l}\text { Essential } \\
\text { Crystallinity }\end{array}$ \\
Microstructure & \\
Optical and electronic properties & Matrix dependent \\
\hline
\end{tabular}


Bulk powder properties (important for dosimetry/exposure)

Concentration (can be measured as mass, surface area, or number concentrations)

Specific surface area/porosity

Essential

Surface chemistry/reactivity

Surface adsorbed species

Surface charge/Zeta potential (especially in aqueous biological environment - may

Important change according the environment)

Surface hydrophobicity

Essential

Different procedures were proposed to evaluate nanotoxicology including in vivo, in vitro, and in silica tests. In vivo tests could provide information regarding identification of the accumulation site, and toxicological profile within a specific organ. This model has some limitations such time-consuming, high costs, and ethical issues. In this procedure, nanoparticles should be delivered from one organ to another one. In vitro examination, nanoparticles are injected in one specific organ. Also, this test could provide information on toxicity mechanism. In silica test could identify the interactions of chemicals with biochemical pathways. Table 2-3, provides information of different toxicology evaluation test (Rai and Biswas, 2019).

Table 2-3. Different Toxicity evaluation test (Rai and Biswas, 2019)

\begin{tabular}{|c|c|c|}
\hline & System & Remark \\
\hline \multirow{3}{*}{ In vitro } & $\begin{array}{l}\text { Cell } \\
\text { assays }\end{array}$ & $\begin{array}{l}\text { Provides information on cell death under controlled } \\
\text { reproducible conditions }\end{array}$ \\
\hline & $\begin{array}{l}\text { DNA damage } \\
\text { assays }\end{array}$ & $\begin{array}{l}\text { Assess the mechanisms underlying DNA damage and } \\
\text { repair }\end{array}$ \\
\hline & Oxidative stress & $\begin{array}{l}\text { Good correlation with damage to cellular } \\
\text { macromolecules }\end{array}$ \\
\hline
\end{tabular}




\begin{tabular}{|c|c|c|}
\hline \multirow{5}{*}{ In vivo } & Figher animals & Ethical issues, expensive, time-consuming \\
\hline & C. elegans & $\begin{array}{l}\text { Provides data from a whole animal with intact and } \\
\text { metabolically active systems }\end{array}$ \\
\hline & G. mellonela & $\begin{array}{l}\text { Many larvae can be used in each experiment making } \\
\text { pharmacological data easy to obtain }\end{array}$ \\
\hline & D. rerio & $\begin{array}{l}\text { Zebrafish develop most of the major organ systems } \\
\text { present in mammals }\end{array}$ \\
\hline & $\begin{array}{l}\text { Transcriptome } \\
\text { analysis }\end{array}$ & $\begin{array}{l}\text { Provides a global view of gene expression under } \\
\text { exposure to different stressors }\end{array}$ \\
\hline \multirow[t]{2}{*}{ In silica } & Metabolomics & $\begin{array}{l}\text { Provides detailed information on the biochemical status } \\
\text { of a } \\
\text { biological system, and about the changes caused by } \\
\text { chemicals }\end{array}$ \\
\hline & Proteomics & Identification of toxicity biomarkers and mechanisms \\
\hline
\end{tabular}

\subsubsection{Toxicity of nanoclays}

Clay minerals are reliable materials which have a great number of applications. Nanoclay term is associated with clay minerals such as alumina and silica and usually these materials are incorporated in other compounds such as polymers (Rai and Biswas, 2019). Due to large applications of nanoclays especially in food packaging, concerns related to potential harms of nanoclays on human and animals has been increased. Different studies have been conducted to analyze the toxicity of nanoclays based on organic modifier or the size[4,5]. These toxicological evolutions were conducted in cell lines and animals using the aforementioned models(Rai and Biswas, 2019). Regarding organic modifier, for instance, Meibian et al.(2010) found that activated bentonite surface characteristics played key role in toxicity. Also, Janer et al. (2014) investigated the toxicity different between different modifiers. According to authors, nanoclays being modified with dimethyl benzyl hydrogenated tallow ammonium was more toxic than nanoclays being modified with dimethyl dehydrogenated tallow ammonium. Due to small sizes, it was proposed that 
nanoclays could have inhalation toxicity for human which means that small sizes would allow them to inhale in the body and deposit in lungs. Verma et al. (2011) studied this theory with two both of platelet and tubular shapes of nanoclays using in vitro models. The dosage range for that study was from 1 to $250 \mu \mathrm{g} \mathrm{mL}^{-1}$. According to the results, tubular nanoclays did not prompt any toxicity until dose $250 \mu \mathrm{g} \mathrm{mL} \mathrm{m}^{-1}$ while for platelet shape prompted toxicity at dose $25 \mu \mathrm{g} \mathrm{mL}^{-1}$. Furthermore, some studies were conducted to investigate the possibility of nanoclays interaction with humans through digestion. These studies were developed to understand the effects of nanoclays on the ingestion cell lines. The results demonstrated that toxic effect of Cloisite $30 \mathrm{~B}$ on human hepatocellular carcinoma epithelial cell line could stop cellular growing. Table 2-4 summarizes the toxicity studies have been done regarding nanoclays.

Table 2-4. Nanoclays toxicity evaluation

\begin{tabular}{|c|c|c|c|}
\hline Nanoclay & Evaluation system & Major outcome & Reference \\
\hline $\begin{array}{l}\text { Montmorilloninte, } \\
\text { halloysite, kaolin, } \\
\text { bentonite }\end{array}$ & P. caudatum & $\begin{array}{l}\text { Very low or no } \\
\text { toxicity }\end{array}$ & $\begin{array}{l}\text { (Kryuchkova } \\
\text { et al., 2016) }\end{array}$ \\
\hline $\begin{array}{l}\text { Cloisite } \mathrm{Na}+\text { and } \\
\text { Cloisite } 30 \mathrm{~B}\end{array}$ & Lung epithelial cells & $\begin{array}{l}\text { Toxic effects with } \\
\text { decrease in cell } \\
\text { viability }\end{array}$ & $\begin{array}{l}\text { (Wagner, } \\
\text { 2018) }\end{array}$ \\
\hline $\begin{array}{l}\text { Cloisite } \mathrm{Na}+\text { and } \\
\text { Cloisite } 93 \mathrm{~A}\end{array}$ & HepG2 cells & Significant cell death & $\begin{array}{l}\text { (Lordan et } \\
\text { al., 2011) }\end{array}$ \\
\hline Nanoclay & Mice & $\begin{array}{l}\text { Potential hepato and } \\
\text { nephrotoxicity }\end{array}$ & $\begin{array}{l}\text { (Isoda et al., } \\
\text { 2017) }\end{array}$ \\
\hline $\begin{array}{l}\text { Cloisite } \mathrm{Na}+\text { and } \\
\text { Cloisite } 30 \mathrm{~B}\end{array}$ & HepG2 cells & $\begin{array}{l}\text { Genotoxic effects } \\
\text { and morphological } \\
\text { alterations by } \\
\text { Cloisite 30B }\end{array}$ & $\begin{array}{l}\text { (Maisanaba } \\
\text { et al., 2013) }\end{array}$ \\
\hline $\begin{array}{l}\text { Cloisite } \mathrm{Na}+\text { and } \\
\text { Cloisite } 30 \mathrm{~B}\end{array}$ & Caco- 2 cells & $\begin{array}{l}\text { Oxidative stress and } \\
\text { morphological } \\
\text { alterations by } \\
\text { Cloisite 30B }\end{array}$ & $\begin{array}{l}\text { (Houtman et } \\
\text { al., 2014) }\end{array}$ \\
\hline Halloysite & $\begin{array}{l}\text { HepG } 2 \text { and HCT } 116 \\
\text { cells }\end{array}$ & $\begin{array}{l}\text { General safe at } \\
\text { practical doses }\end{array}$ & $\begin{array}{l}\text { (Mosselhy et } \\
\text { al., 2015) }\end{array}$ \\
\hline Halloysite & C. elegans & $\begin{array}{l}\text { Absence of toxic } \\
\text { effects }\end{array}$ & $\begin{array}{l}\text { (Fakhrullina } \\
\text { et al., 2015) }\end{array}$ \\
\hline
\end{tabular}

\subsubsection{Toxicity mechanism}


Due to their small size, the possibility of entering nanoclays in the body without being trapped with defence mechanism is high (Vlastou et al., 2017). The toxic effects of nanoclays on the cells depends on organism characteristics and environmental conditions. Recent studies have been aimed to understand nanoclay-induced toxicity mechanism because of changes that could occur in cellular viability when it is subjected to nanoclay. The most common problems arise from nanoclay exposure are reactive oxygen species (ROS) overproduction such as Hydroxyl radical, Singlet oxygen, Superoxide anion, Hydrogen peroxide, Hypoclorious acid. Nanoclay could affect the cellular in different paths. Subjection to nanoclay could cause damage in cellular structure because these nano materials could interact with membrane and lead to membrane lysing ability (Murphy, 2009). The second proposed mechanism is that nanoclay could affect the living cellular through changes in mitochondrial (Murphy et al., 1993). Maisanaba et al. (2014) studies have confirmed that mitochondria of cells have degraded when they exposed to nanoclays.

(Fig 2-6)

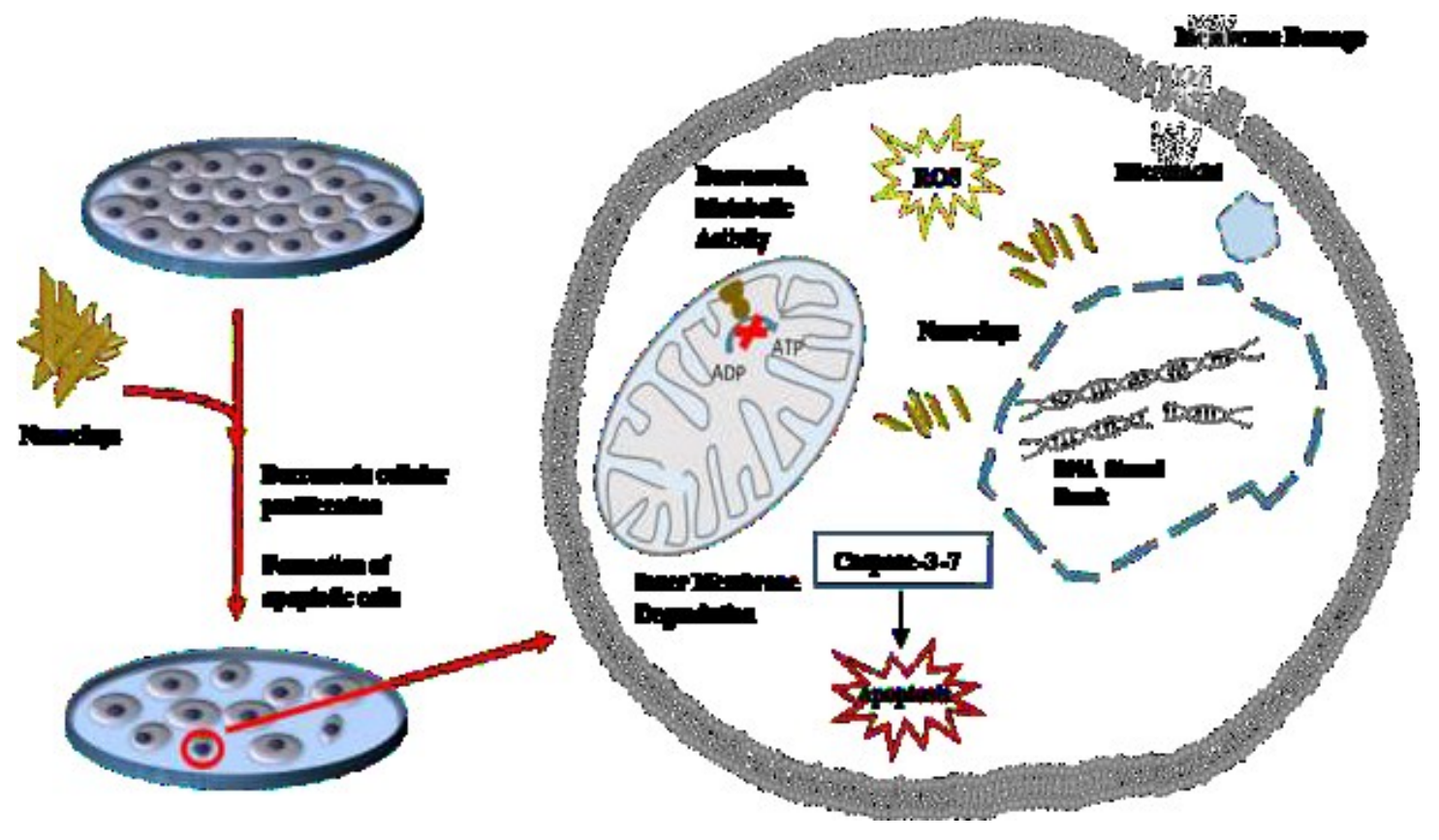

Figure 2-6. Schematic of toxicity mechanism caused by cellular subjection to nanoclay

(Wagner, 2018) 


\section{CHAPTER 3. MATERIALS AND METHODS}

\subsection{Materials and chemicals}

Bentonite nanoclay in powder shape was purchased from Sigma Aldrich (St. Louis, USA). Crude oil was obtained from Hibernia oil field located in the southeast of St. John's, Newfoundland, Canada. Standard washed and ignited sand (30-40 mesh) was purchased by Millipore (ON, Canada). Sea salt was purchased from Sigma Chemical Company (ON, Canada) and hexane was purchased from Fisher Scientific (ON, Canada) at analytical grade. Deionized water was used in all tests.

\subsection{Experimental procedure}

Sand was mixed with crude oil to reach a concentration of $4 \mathrm{~g} \mathrm{oil} \mathrm{kg}^{-1}$ sand. The samples were put in the fume hood for 7 days for weathering. Nanoclay was dispersed in deionized water using ultrasonicator for $30 \mathrm{~min}$ at the amplitude of $30 \% .15 \mathrm{~mL}$ of prepared nanofluid and $0.5 \mathrm{~g}$ of contaminated sand were put in a sealed vial. The vials were put in the shaker at $300 \mathrm{rpm}$ for $24 \mathrm{hr}$. Then, the liquid in the vial was decanted and $15 \mathrm{~mL}$ hexane was added to the remaining sand. The mixture was shaking at $300 \mathrm{rpm}$ to extract the oil left on the sand. After $24 \mathrm{hr}$, the supernatant was used for further analysis of oil content.

\subsection{Full factorial design}

For evaluating the factors that have effects on the oil removal by nanoclay, the full factorial design was applied (Design Expert software). This approach has been widely applied to investigate the effects of factors and their interactions in environmental processes. In this study, four shoreline environmental characteristics (nanoclay concentration, salinity, temperature, and $\mathrm{pH}$ ) that affected oil removal efficiency at two levels were analyzed. The low and high levels were coded as -1 and +1 , respectively (Table 3-1). The 48 runs of experiments were conducted, and the details are shown in Table 3-2. One-way analysis of 
variance (ANOVA) with least significance difference test was performed to identify treatments that were statistically different.

Table 3-1. Experimental variable factors for chemical properties of flush water

\begin{tabular}{lllll}
\hline \multirow{2}{*}{ Symbol } & Factor & Units & \multicolumn{2}{c}{ Level } \\
\cline { 4 - 5 } & & & Low (-1) & High (+1) \\
\hline $\mathrm{A}$ & Concentration & $\mathrm{mg} \mathrm{L}^{-1}$ & 100 & 800 \\
$\mathrm{~B}$ & Salinity & $\%$ & 1 & 4 \\
$\mathrm{C}$ & Temperature & ${ }^{\circ} \mathrm{C}$ & 5 & 20 \\
$\mathrm{D}$ & $\mathbf{p H}$ & & 5 & 9 \\
\hline
\end{tabular}

Table 3-2. Corresponding values for factorial design matrix

\begin{tabular}{|c|c|c|c|c|}
\hline Number & $\mathbf{A}$ & B & C & D \\
\hline & $\begin{array}{l}\text { Nanoclay } \\
\text { concentration(ppm) }\end{array}$ & $\begin{array}{l}\text { Salinity } \\
\text { (wt.\%) }\end{array}$ & $\begin{array}{l}\text { Temperature } \\
\left({ }^{\circ} \mathrm{C}\right)\end{array}$ & $\mathrm{pH}$ \\
\hline 1 & 800 & 4 & 5 & 9 \\
\hline 2 & 100 & 1 & 5 & 9 \\
\hline 3 & 800 & 1 & 5 & 9 \\
\hline 4 & 800 & 4 & 5 & 5 \\
\hline 5 & 800 & 4 & 5 & 5 \\
\hline 6 & 100 & 4 & 5 & 9 \\
\hline 7 & 800 & 4 & 20 & 9 \\
\hline 8 & 800 & 4 & 5 & 9 \\
\hline 9 & 800 & 1 & 20 & 9 \\
\hline 10 & 100 & 1 & 5 & 5 \\
\hline 11 & 800 & 1 & 5 & 9 \\
\hline 12 & 800 & 4 & 20 & 9 \\
\hline 13 & 100 & 1 & 20 & 9 \\
\hline 14 & 100 & 1 & 20 & 5 \\
\hline 15 & 800 & 1 & 20 & 5 \\
\hline 16 & 100 & 1 & 5 & 5 \\
\hline 17 & 100 & 4 & 20 & 9 \\
\hline 18 & 800 & 4 & 20 & 5 \\
\hline 19 & 100 & 1 & 5 & 5 \\
\hline
\end{tabular}




\begin{tabular}{lllll}
\hline $\mathbf{2 0}$ & 100 & 4 & 5 & 5 \\
$\mathbf{2 1}$ & 100 & 4 & 20 & 9 \\
$\mathbf{2 2}$ & 800 & 4 & 5 & 9 \\
$\mathbf{2 3}$ & 100 & 4 & 5 & 9 \\
$\mathbf{2 4}$ & 100 & 4 & 20 & 5 \\
$\mathbf{2 5}$ & 100 & 4 & 20 & 5 \\
$\mathbf{2 6}$ & 800 & 4 & 5 & 5 \\
$\mathbf{2 7}$ & 100 & 1 & 20 & 9 \\
$\mathbf{2 8}$ & 100 & 4 & 5 & 9 \\
$\mathbf{2 9}$ & 800 & 4 & 5 & 9 \\
$\mathbf{3 0}$ & 100 & 1 & 20 & 5 \\
$\mathbf{3 1}$ & 800 & 1 & 5 & 9 \\
$\mathbf{3 2}$ & 100 & 4 & 20 & 5 \\
$\mathbf{3 3}$ & 100 & 1 & 20 & 5 \\
$\mathbf{3 4}$ & 800 & 1 & 20 & 5 \\
$\mathbf{3 5}$ & 800 & 1 & 5 & 9 \\
$\mathbf{3 6}$ & 800 & 1 & 5 & 5 \\
$\mathbf{3 7}$ & 800 & 4 & 20 & 5 \\
$\mathbf{3 8}$ & 100 & 4 & 5 & 5 \\
$\mathbf{3 9}$ & 800 & 1 & 20 & 9 \\
$\mathbf{4 0}$ & 100 & 1 & 20 & 9 \\
$\mathbf{4 1}$ & 800 & 1 & 20 & 5 \\
$\mathbf{4 2}$ & 100 & 4 & 20 & 9 \\
$\mathbf{4 3}$ & 100 & 1 & 20 & 5 \\
$\mathbf{4 4}$ & 100 & 4 & 20 & 9 \\
$\mathbf{4 5}$ & 800 & 4 & 5 & 5 \\
$\mathbf{4 6}$ & 800 & 4 & 5 & 5 \\
$\mathbf{4 7}$ & 100 & 1 & 5 & 9 \\
$\mathbf{4 8}$ & 800 & & 5 & 9 \\
\hline & & 4 & \\
\hline
\end{tabular}

\subsection{Analytical methods}

The concentration of oil in hexane was measured using a Thermo Scientific ${ }^{\mathrm{TM}}$ Evolution 201 UV-Visible spectrophotometer (MA, USA) at wavelength of $220 \mathrm{~nm}$. A Jenway 3310 $\mathrm{pH}$ meter (Jenway Ltd., UK) was used to determine the $\mathrm{pH}$ of solution. The particle size distribution of nanoclay suspension $\left(800 \mathrm{mg} \mathrm{L}^{-1}\right)$ were measured at $25^{\circ} \mathrm{C}$ using Nano ZS Zetasizer (Malvern, USA). The nanoclay suspension was prepared using ultrasonic probe 
with the frequency of $20 \mathrm{kHz}$ and a tapered microtip. The ultrasonic probe worked with power of $25 \mathrm{~W}$ and a pulse cycle ON-OFF of 5-2 s for total time of $30 \mathrm{~min}$. All batch experiments were conducted in triplicate, and the results were reported as the average value. The experimental arrangement and results analysis of factorial design were performed using Design Expert 11 (Stat-Ease Inc., MN, USA). Statistical analysis was undertaken through one-way ANOVA (p-value $<0.0001$ ).

\subsection{Miscibility modeling}

From the perspective of thermodynamics, a miscible blend is usually indicated from a negative or zero free energy of mixing $(\Delta G \leq 0)$ but a positive second derivative of $\Delta G$ with respective to composition $\left(\frac{\partial^{2} \Delta G}{\partial \phi^{2}}\right)$ (Marsh, 2007). The Flory-Huggins theory has been one of the most commonly-accepted theoretical models which is applicable for solvent/polymer-solvent mixtures in various chemical processes, particularly, for the chain-like alkanes and water following the equation below (Flory, 1942; Huggins, 1942),

$$
\Delta G=\chi_{12} R T \phi_{1} \phi_{2}+R T\left(n_{1} \ln \phi_{1}+n_{2} \ln \phi_{2}\right)
$$

where $\chi_{12}$ is the Flory-Huggins interaction parameter, $R$ is the universal gas constant, $T$ is system temperature, $n_{1}$ and $n_{2}$ are respective molecule numbers of components 1 and 2 on the molecular basis, $\phi_{1}$ and $\phi_{2}$ are the respective molar concentrations of the components 1 and 2. However, the conventional Flory-Huggins theory may not be capable to properly handle the additions of nanoclay. Recently, a modified thermodynamic model was developed to predict the thermodynamic miscibility of the oil-water system with additions of surfactant-decorated nanoparticles (Zhang et al., 2018). Based on the previous study, the free energy of mixing for the system here is presented as follows,

$$
\Delta G=\Delta G_{\text {flu }}+\Delta G_{\text {np }}
$$

where $\Delta G_{\text {flu }}$ is the free energy from the interactions between the water and nanoparticles and $\Delta G_{\text {np }}$ is the free energy contributed by the nanoparticles. The free energy between the oil and pure water is assumed to be negligible here since with the additions of nanoparticles, 
water phase is modified while the oil phase has almost no change and its effect is thus very small. In this case, Eq. 2 could be rearranged and presented to be,

$$
\Delta G_{\mathrm{m}}=\frac{\phi}{v_{\mathrm{p}}}(1-\phi) p\left(\frac{r_{\mathrm{NP}}}{r_{0}}\right) \frac{3 r_{N P}^{2}}{2 \sqrt{v_{1} v_{2}} r_{0}^{2}}+\chi_{\mathrm{flu}} \phi\left(\frac{r_{0}}{r_{\mathrm{NP}}}\right)(1-\phi)+\frac{\phi}{v_{\mathrm{p}}}\left[\ln \phi+p\left(\frac{r_{\mathrm{NP}}}{r_{0}}\right) \frac{4 \phi-3 \phi^{2}}{(1-\phi)^{2}}\right]
$$

where $\phi$ is the weight fraction of nanoparticles, $r_{\mathrm{NP}}$ is the radius of a single nanoparticle, $r_{0}$ is the monomer radius, $v_{\mathrm{Np}}$ is the volume of a single nanoparticle, $\chi_{\mathrm{flu}}$ is the FloryHuggins interaction parameter between the water and nanoparticles. It should be noted that the nanoparticle is assumed to be a spherical hydrophilic particle and the model is restricted

to pure water (without salinity change) in this study. More details could be found elsewhere (Zhang et al., 2018), which could be checked if interested and won't be duplicated here.

\subsection{Dynamic simulation}

The molecular dynamics (MD) simulation for oil droplet in the aqueous suspension of montmorillonite (major component of bentonite) was conducted. The oil droplet in our study was modeled as a mixture of 250 octane molecules, which is similar with a previous study about oil-water interface dynamics (Liang et al., 2019). The solvent environment consisted of 14,127 water molecules and 25 rigid montmorillonite nanoparticles with a diameter of approximately $1.4 \mathrm{~nm}$ which were evenly distributed. The initial configuration was built using Packmol (Martinez et al., 2009). The CHARMM force field was used to model the bond, angle, dihedral, van der Waals and electrostatic interactions among the hydrocarbon molecules (Vorobyov et al., 2007). The water molecules were described by the SPC/E model (Berendsen et al., 1987), which consists of a Lennard -Jones (LJ) potential between oxygen atoms and a Coulomb potential between partial point charges on the oxygen and hydrogen atoms. A cut-off of $12.0 \AA$ was used for the van der Waals interactions. The long-range electrostatic interactions were computed using the particleparticle particle-mesh (PPPM) algorithm, with a convergence parameter of $10^{-3}$. The length along the $\mathrm{Y}$ direction was rather small compared with that along $\mathrm{X}$. This quasi-twodimensional setup not only made it easy to calculate the contact angle of the oil droplet and monitor the motion of the three-phase contact line, but also reduced the computational time. 
All the simulations were performed in the canonical ensemble (NVT). The temperature was set to $298 \mathrm{~K}$ using a Nos'e-Hoover thermostat. The trajectories were collected in an interval of $1.0 \mathrm{ps}$ for further analysis. The MD simulations in the present study were performed using LAMMPS (Plimpton, 1995). The snapshots were prepared using VMD (Humphrey et al., 1996). In the absence of montmorillonite, the contact angle of the oil droplet on this solid surface was approximately $60.0^{\circ}$ after the equilibrium as shown in Fig 3-1. The MD simulations of oil droplet detachment from the solid substrate immersed in suspensions of montmorillonite with $-0.22 \mathrm{e}$ were conducted. To maintain the electroneutrality of the system, opposite charges were assigned to atoms in the bottom layer of the substrate.

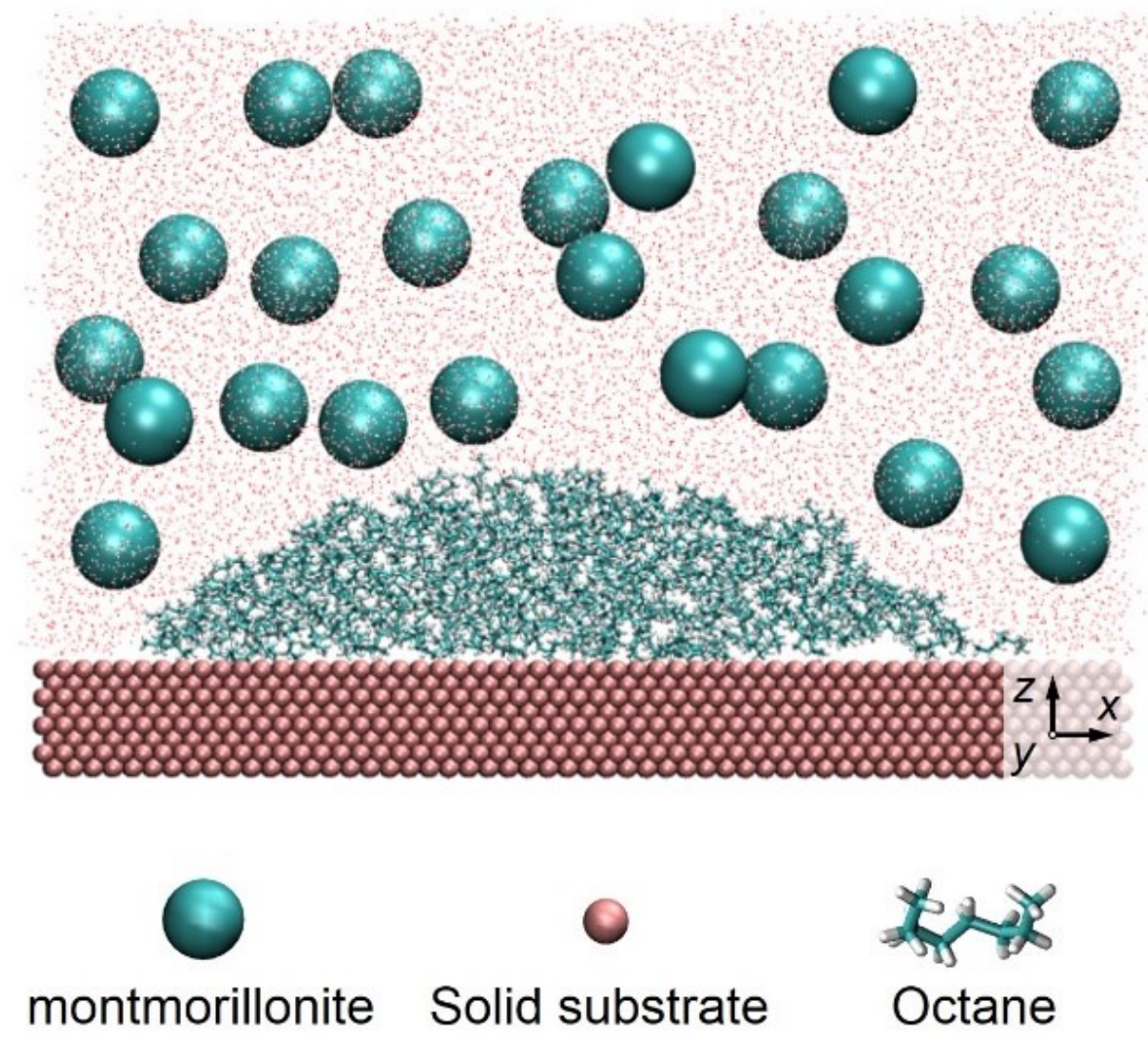

Figure 3-1. Snapshot of the oil on the solid substrate with montmorillonite particle 


\section{CHAPTER 4. RESULTS AND DISCUSSION}

\subsection{The effect of nanoclay concentration on oil behavior}

The effect of different nanoclay concentrations on oil behaviour in water-sand system was investigated and the results are shown in the Fig 4-2. It can be seen that by increasing in nanoclay concentration from 100 to $4000 \mathrm{mg} \mathrm{L}^{-1}$, the remaining oil on sand decreased from 957.46 to $487.91 \mathrm{mg} \mathrm{kg}^{-1}$. Nanoclay is formed as a result of chemical weathering of other silicate minerals. It is often featured by the small particle size, high specific surface area, and high CEC. Fig 4-1 shows the particle size distribution of nanoclay suspension (800 mg $\left.\mathrm{L}^{-1}\right)$. It can be seen that the average size of nanoclay was around $109.5 \mathrm{~nm}$, in which $95.5 \%$ of the nanoclay particles had a diameter of $109.5 \mathrm{~nm}$ and $3.9 \%$ of the particles had a diameter of $15.2 \mathrm{~nm}$. The XRD results in Fig 4-1 shows the major montmorillonite component of bentonite. It has been reported that nanoclay can be combined with some pollutants. Adsorption of organic materials through weak Van der Waals forces on the surfaces of clay minerals can play a significant role in linking organic matter to the surface of clays (Stevenson, 1994). Organic materials such as fulvic acid could be adsorbed into the space between the layers of montmorillonite. The swelling characteristic of nanoclay may create the interlayers in its structure, which is also favorable for retaining other substances (Churchman et al., 2006). In this sand-water system, the oil could be combined with nanoclay in water. The existence of nanoclay will shift the equilibrium between oil on sand and oil in water; resulting more oil detached from sand and less residual oil on sand. When approaching the oil detachment limit, the increase of nanoclay concentration would not result in further decrease of residual oil on sand. 


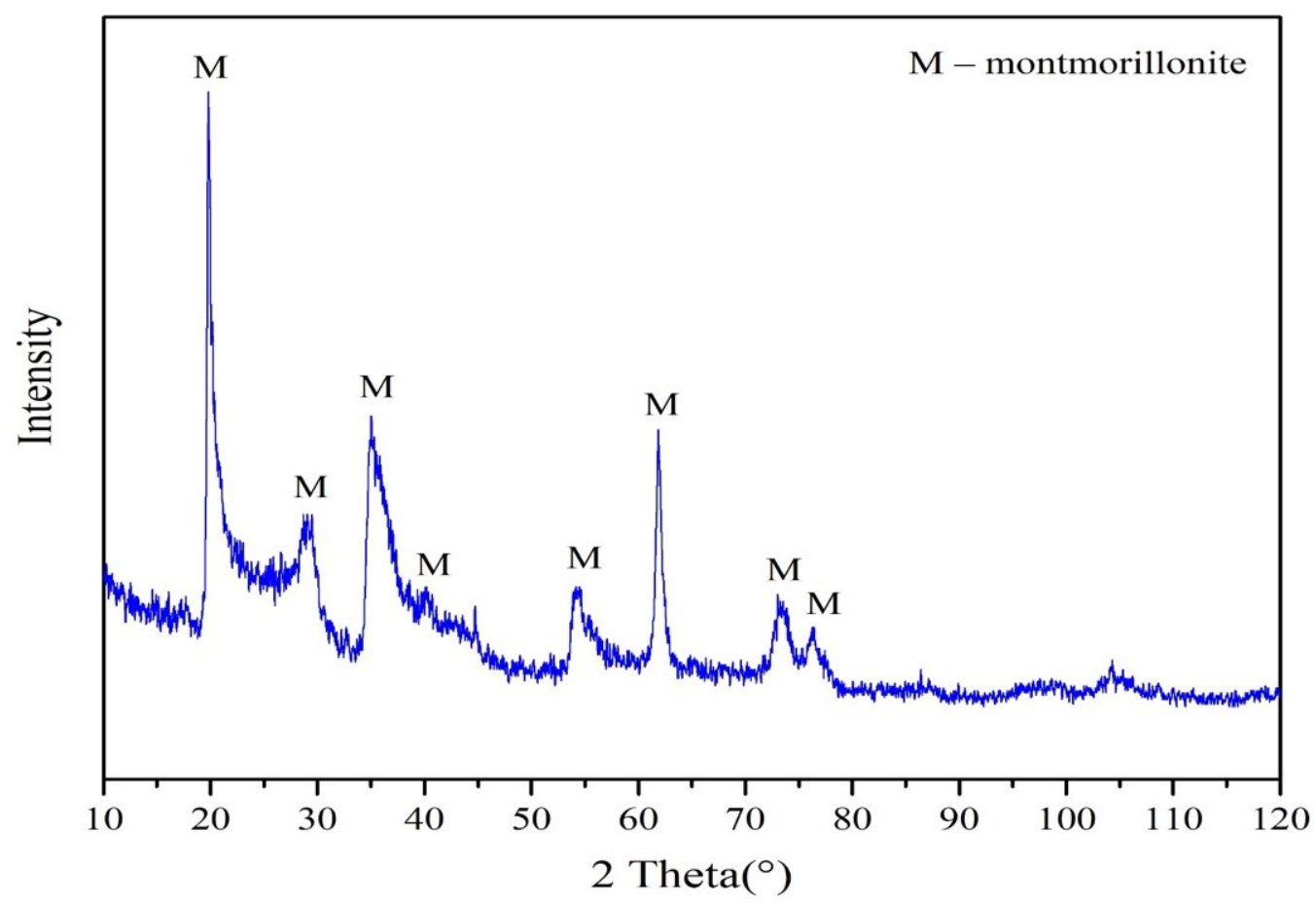

Figure 4-1. XRD of bentonite nanoclay

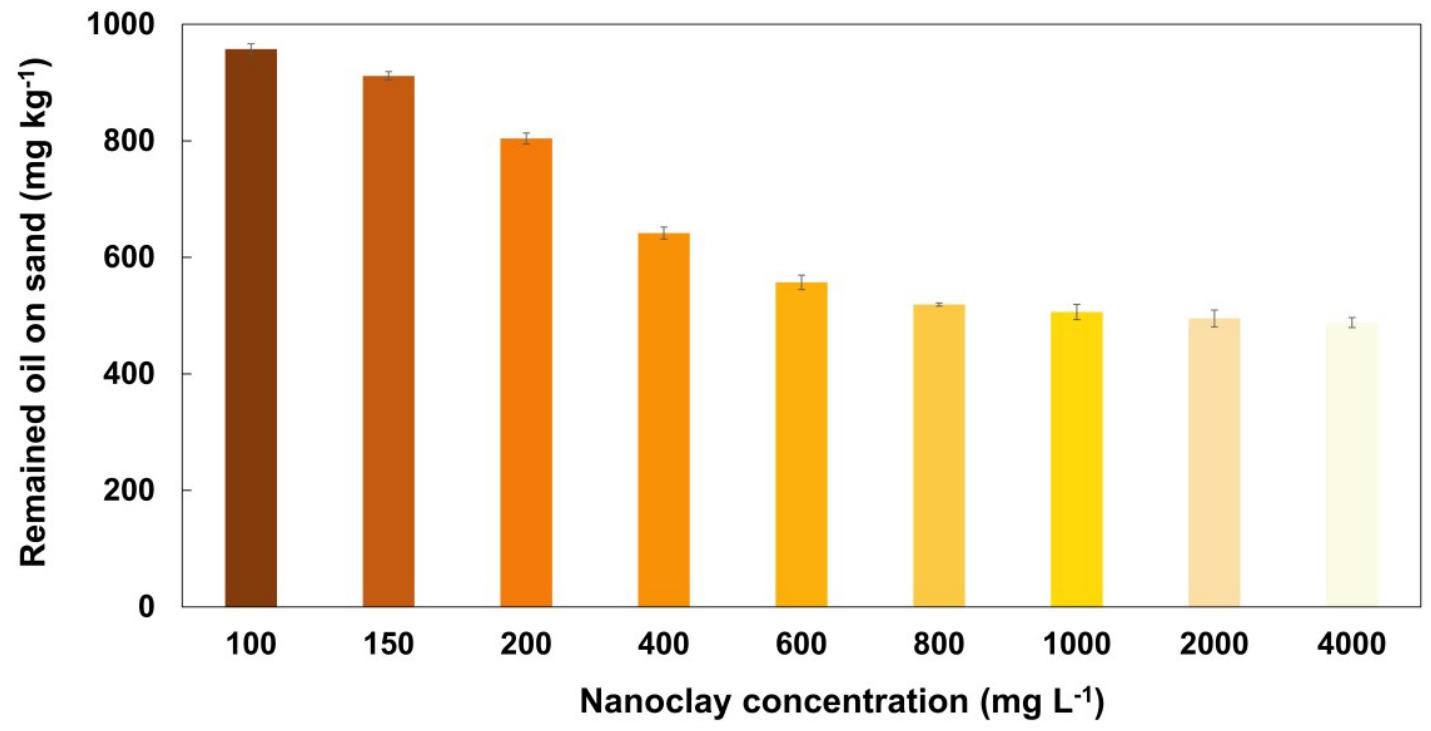

Figure 4-2. The effect of nanoclay concentration on oil behavior 


\subsection{Effect of temperature on oil behavior}

One of the important environmental parameters which can affect the pollutant transport behaviors is temperature (Bi et al., 2020; Chen et al., 2021; Shen et al., 2017). Temperature exerts major effects on the physical properties of oil, such as viscosity, surface tension and density. That may influence the oil's transport and environmental persistence. The temperature of natural shoreline environment may vary greatly in different regions. The temperature range of $5-30{ }^{\circ} \mathrm{C}$ was studied to determine its impact on oil behaviors in the presence of $800 \mathrm{mg} \mathrm{L}^{-1}$ nanoclay. As shown in Fig 4-3, the oil residue on sand decreased as temperature increased in the presence of $800 \mathrm{mg} \mathrm{L}^{-1}$ nanoclay. The oil residue on sand decreased from $99.62 \%$ at $5^{\circ} \mathrm{C}$ to $42.37 \%$ at $30^{\circ} \mathrm{C}$, almost half of original residue amount. Such decrease is mainly due to the impact of temperature on oil adhesion at sand surface. Oil viscosity is directly related to the temperature and it decreases with increase in temperature. At low temperatures, the viscosity of the oil increases and at high-viscosity oil can be captured onto the rough surface easily. With an increase in temperature, the oil viscosity decreased. It would be favorable for the detachment of oil from sand. High temperature could also result in the enhanced movement of absorbate molecules, which increased the diffusion of adsorbed oil from sand surface.

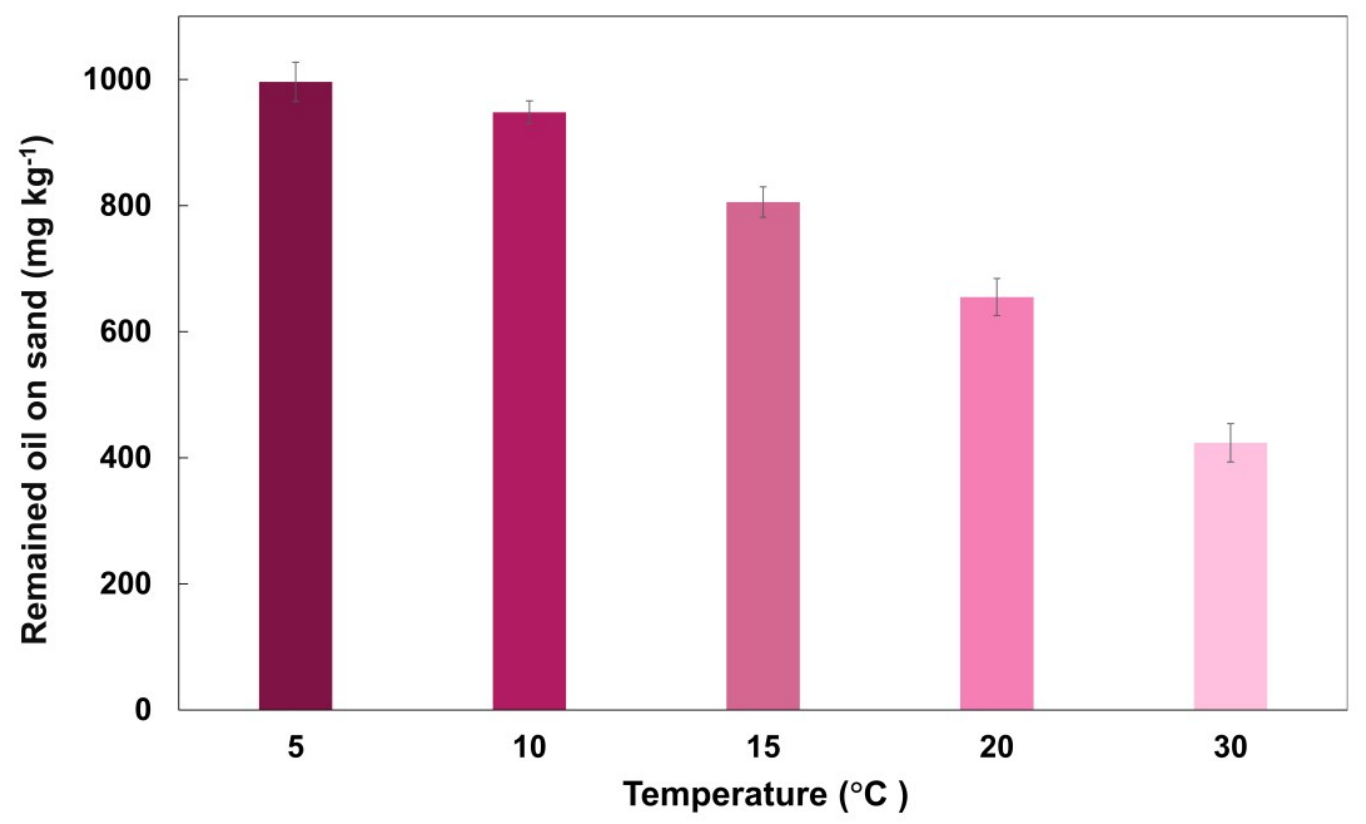

Figure 4-3. The effect of temperature on oil behavior 


\subsection{Effect of salinity on oil behavior}

The average salinity of seawater is around $3.5 \mathrm{wt} \%$ and this level may vary at different areas (Aksu and Balibek, 2010). In seashores, seawater can be less salty due to the fresh water from rivers and streams. In this study, the salinity with the range of 0 to $6.0 \mathrm{wt} . \%$ was used to investigate its effect on the residual oil on sand in the presence of $800 \mathrm{mg} \mathrm{L}^{-1}$ nanoclay and the results are shown in Fig 4-4. It can be seen that the residual oil on sand decreased from 926 to $268 \mathrm{mg} \mathrm{kg}^{-1}$ when increasing the salinity from 1 to $6 \mathrm{wt} . \%$. The increase of salinity at a low level showed only a negligible effect on residual oil, but a remarkable decrease of oil residue can be seen at salinity more than $4 \mathrm{wt}$.\%. The oil residue on the sand decreased by more than half from 657.9 to $330.1 \mathrm{mg} \mathrm{kg}^{-1}$ as the salinity changed from 4 to $5 \%$. The high salinity may lead to the compression of the electric double layer (Molnes et al., 2016; Zhong et al., 2012). The resultant decrease in the repulsion force between particles leads to the aggregation and reduction of the viscosity of the nanofluid. The presence of nanoclay could contribute to the formation of oil particle aggregates (OPAs), which could also promote the oil detachment from sand. OPA formation varied under different seawater salinities. It was reported that more than $75 \%$ of OPAs were formed in seawater (3.4 wt.\% sea salt), while only $10 \%$ were formed in deionized water (Le Floch et al., 2002).

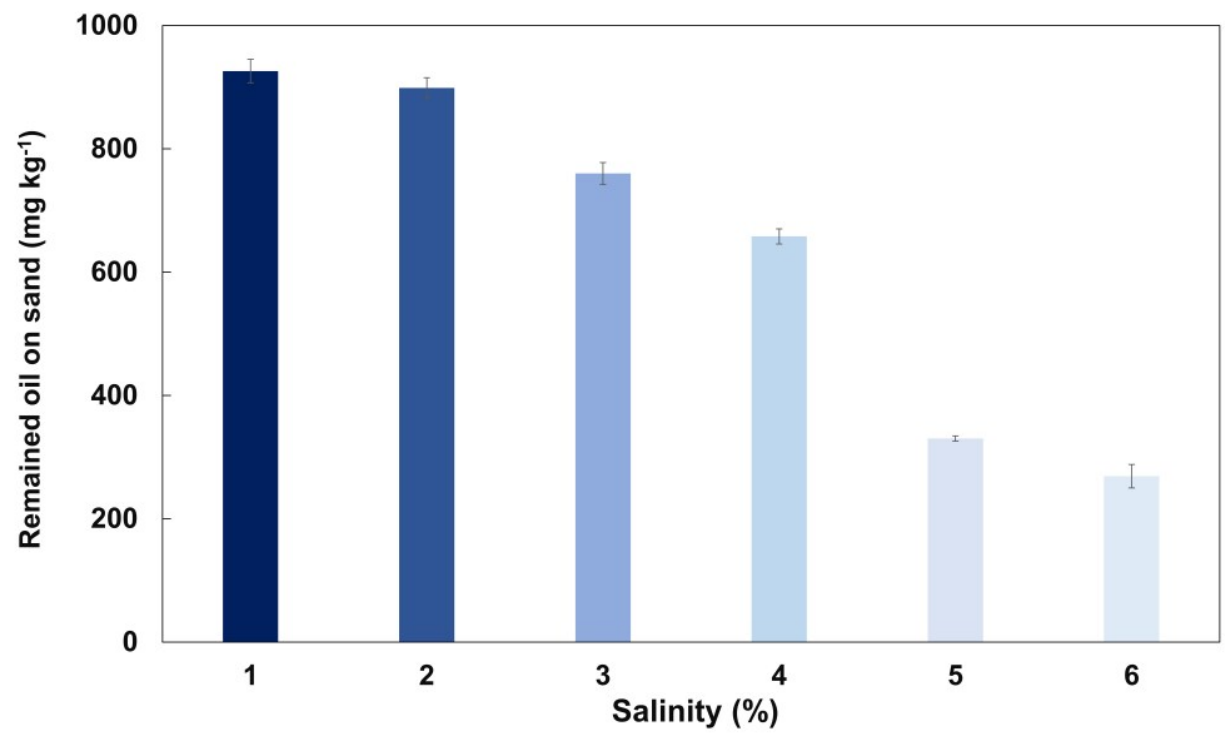

Figure 4-4. The effect of salinity on oil behavior 40 


\subsection{Effect of pH on oil behavior}

The $\mathrm{pH}$ of solution is one of the important parameters which can affect the pollutant transport (Ibrahim et al., 2010; Zhao et al., 2019b). pH in seawater and shoreline sediments may vary considerably (Cleary et al., 2018). Fig 4-5 shows the effect of $\mathrm{pH}$ on oil behavior in the presence of nanoclay. The tests were conducted in the $\mathrm{pH}$ range of 4-10 with the 800 $\mathrm{mg} \mathrm{L}^{-1}$ nanoclay solution, temperature of $20^{\circ} \mathrm{C}$, and the salinity of $0 \%$. The remaining oil decreases from 548.1 to $315.6 \mathrm{mg} \mathrm{kg}^{-1}$ with increasing $\mathrm{pH}$ of solution from 4 to 7 and increases from 315.6 to $505.97 \mathrm{mg} \mathrm{kg}^{-1}$ with further increasing of the $\mathrm{pH}$ of solution from 7-10. The results indicate that $\mathrm{pH}$ variation up to 7 , could influence the transfer of oil from sand to aqueous phase in the presence of nanoclay.

The changes in zeta potentials of sand, oil and nanoclay at different $\mathrm{pH}$ levels played an important role in this process. Both sand particles and oil droplets were often negatively charged (Lim et al., 2016). Jada et al. (2006) observed that the zeta potential of sand particles decreased noticeably when increasing $\mathrm{pH}$ up to 7 and the zeta potential tended to be stable above pH 7. Bonto et al. (2019) reported the zeta potential of different types of oil also decreased (negative value) with increasing $\mathrm{pH}$ from 2 to 7 . As $\mathrm{pH}$ increased from 4 to 7 , there could be increased repulsion between oil and sand sands, resulting less residual oil on sand. When $\mathrm{pH}$ increased above 7, the negative charge of sand and oil tended to be stable. Bentonite could display a negative zeta potential at a wide $\mathrm{pH}$, but its negative charge could become more pronounce above pH 7 (Mekhamer, 2010; Niriella and Carnahan, 2006). At $\mathrm{pH}$ of 7 to 10, the increasing repulsion force between oil and the nanoclay limited their combination, which in turn resulted in more oil retention on sand. 


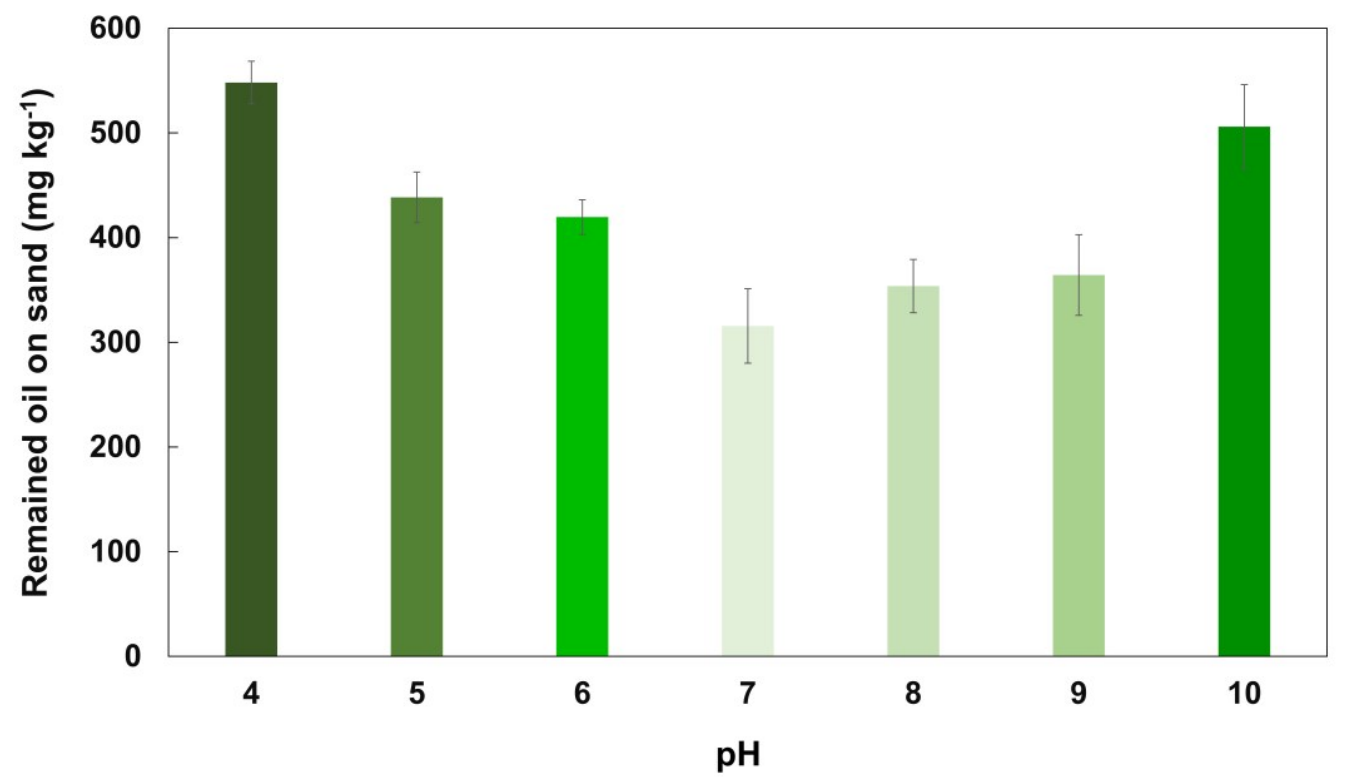

Figure 4-5. The effect of $\mathrm{pH}$ on the oil behavior

\subsection{Factorial analysis of influencing factors}

The study of interactive effects of various factors can help better understand the environmental process (J. Ordieres-Meré, J. Ouarzazi, B. El Johra, 2020; Jeong et al., 2019; Lindenschmidt and Rokaya, 2019; Liu et al., 2020). The statistical analysis results are shown in Table S1. The Pareto chart shows the main and interactive effects for oil behavior in the presence of nanoclay (Fig. 4-6). It can be seen that the nanoclay concentration and salinity played the more noticeable roles among these environmental factors. Fig. 7 (A-D) shows the main effects of individual factors on oil remained on sand. A positive sign of the effect indicated that a high factor setting $(+1)$ resulted in a lower oil remained on sand. The effects of single factor on oil behaviors decreased in the following order: nanoclay concentration $>$ salinity $>$ temperature $>\mathrm{pH}$. An increase in nanoclay concentration from 100 to $800 \mathrm{mg} \mathrm{L}^{-1}$ resulted in the decreased residual oil on sand to as low as $469.55 \mathrm{mg} \mathrm{kg}^{-1}$. The higher nanoclay concentration may lead to less remained oil due to the more available combinations for detached oil in water. There would be higher surface area of nanoclay at the high concentration of nanoclay, which was favorable for the combination with oil. Such result indicates the natural oil removal process should be well 
evaluated if the high clay mineral amount exists in the oiled shoreline. The oil translocation on such high-clay shoreline could be different with that with less clay.

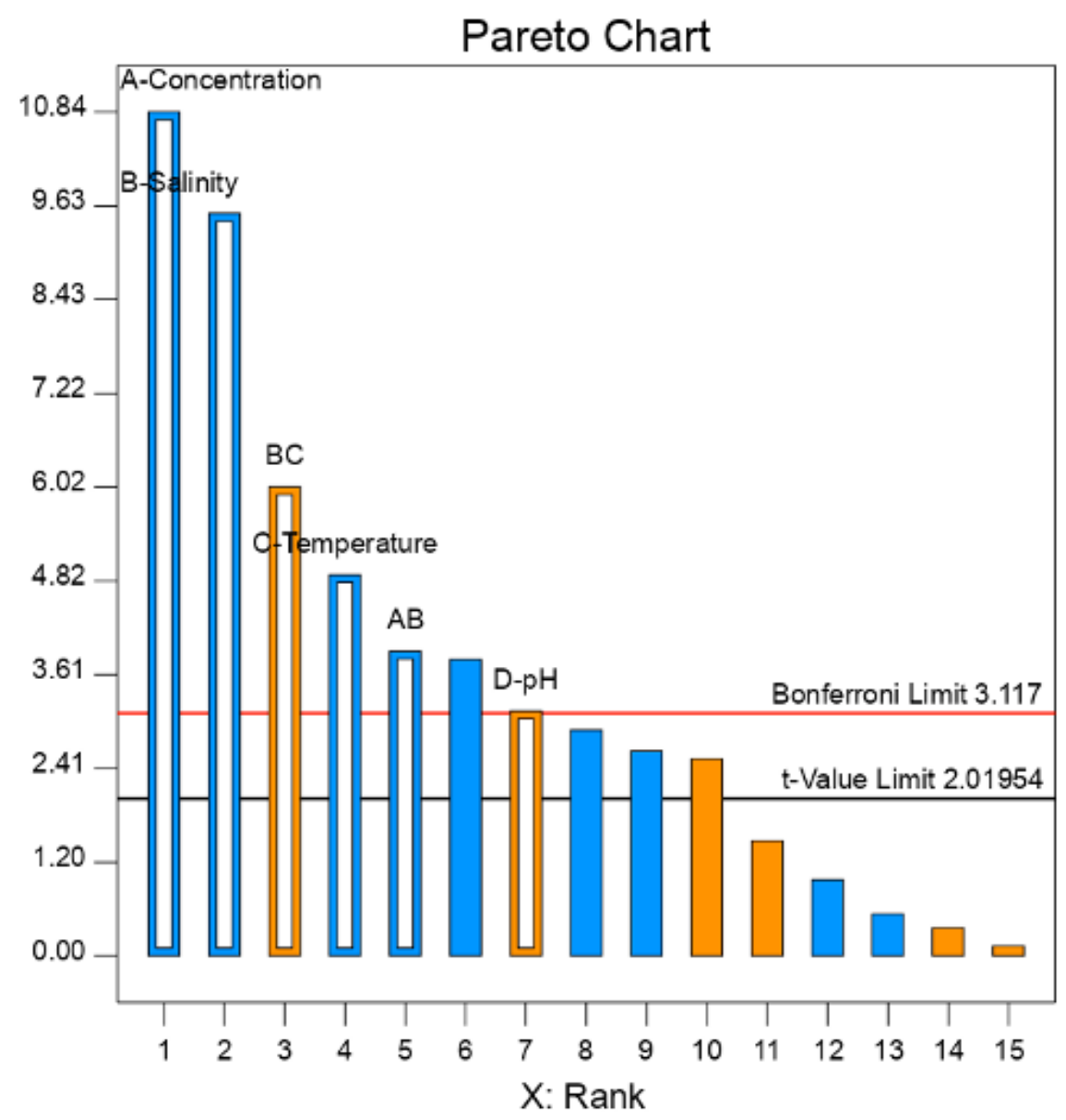

Figure 4-6. Pareto chart in factorial analysis

Fig 4-7 (E-H) shows the significant two-factor interactive effects on oil behaviors. An increase in temperature and salinity would lead to the decrease of remained oil on sand. It has been known that individual factors B-salinity and C-temperature were significant factors for oil behavior, while their two-factor interaction was also significant. Fig 4-7(E) shows the interactive effect of salinity and nanoclay concentration on oil remained on sand. It can be seen that the lowest remained oil on sand could be obtained at high salinity level with increasing nanoclay concentration. It indicates there could be significant change of spilled oil on shoreline in the environment with both high-salinity water and high clay 
concentration. The oil remained on sand could also change under various salinity levels at low and high temperature (Fig 4-7(F)). Less oil remained on sand was obtained at high salinity and high temperature. As seen in Fig 4-7(G), the effect of high-level pH (9) on oil remained on sand was more noticeable in comparison to low-level $\mathrm{pH}$ (5) with increasing of salinity. Fig $4-7(\mathrm{H})$ shows the interactive effect of temperature and $\mathrm{pH}$ on the oil remained on sand. The difference between two $\mathrm{pH}$ levels from low to high temperature remained almost same. With increasing temperature in both $\mathrm{pH}$ levels, the remained oil on sand decreased by approximately $17 \%$.
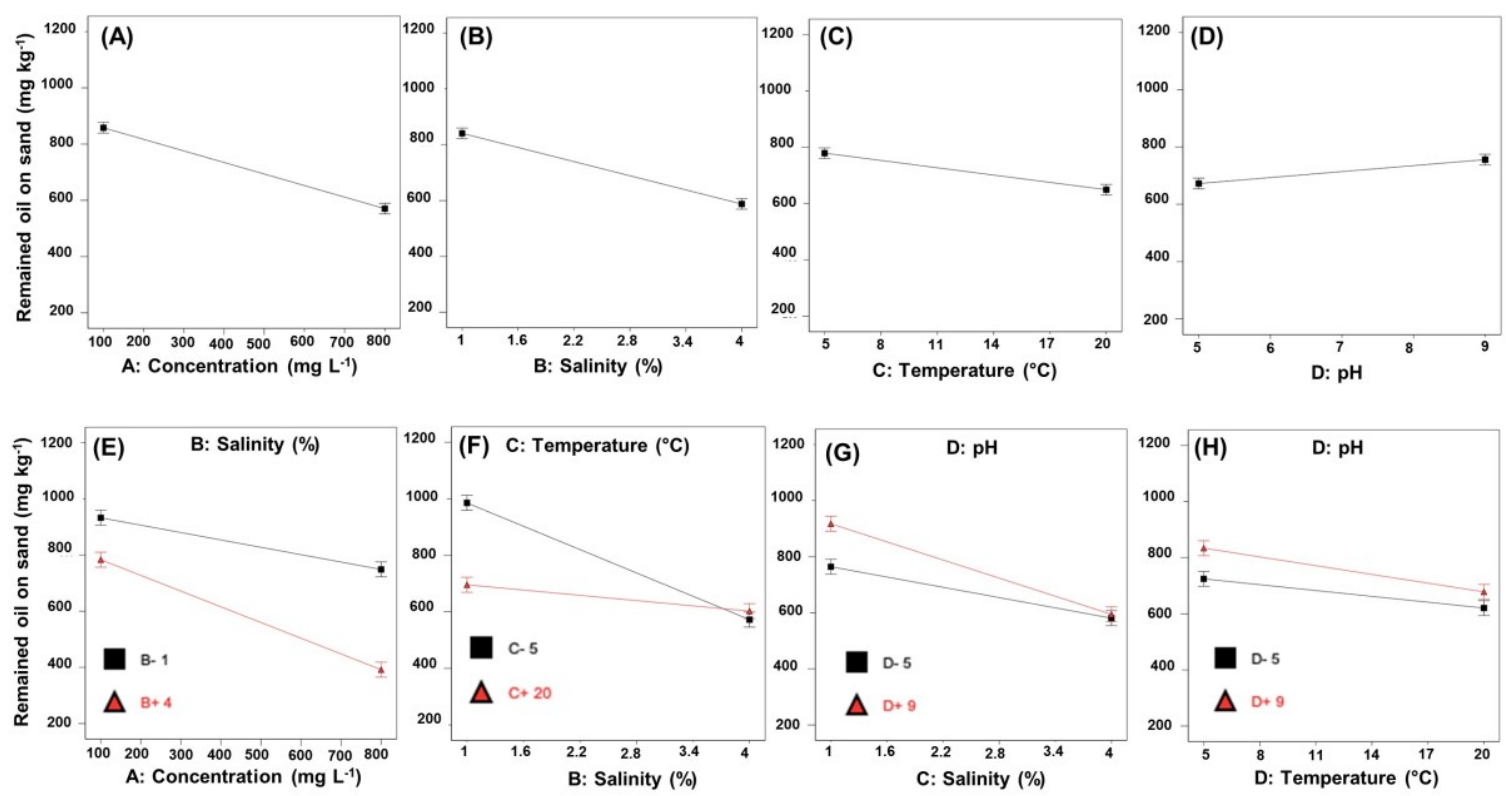

Figure 4-7. (A-D) Plots of the single factors effect, (E-G) Plots of effective double factors

\subsection{Insight from miscibility modeling study}

To better understand the effect of nano clay, the aforementioned theory introduced in 2.5 was used to evaluate the oil-water miscibility by adding nanoclay particles. Fig 4-8 presents the calculated results of the oil-water system with additions of nanoclay at different concentrations from 0 to $4000 \mathrm{mg} \mathrm{L}^{-1}$ and temperatures of 5 to $30^{\circ} \mathrm{C}$ Obviously, the oilwater miscibility was found to be enhanced by adding nanoclay particles up to certain value, while after that any further addition won't be beneficial or even be detrimental to the system miscibility. The overall miscible state was benefitted from more additions of nanoclay only 
if its concentration was controlled below $1000 \mathrm{mg} \mathrm{L}^{-1}$. For concentrations exceeding 1000 up to $4000 \mathrm{mg} \mathrm{L}^{-1}$ (the upper limit of test condition), more nanoclay additions reduced the system miscibility and the corresponding free energy gradually increased. In addition to the concentration of nanoparticle, temperature effect might not be so strong as the concentration but cannot be ignored for the target system in this study. Overall, an increasing temperature is beneficial to the fluid miscibility. More specifically, higher temperatures usually affect the miscibility more in comparison with the lower temperature cases even with the same increase rate (e.g., comparison between cases of $5-15^{\circ} \mathrm{C}$ and 20 $30{ }^{\circ} \mathrm{C}$ ). These modeling results well supported the experimental results, in terms of using thermodynamics to explain the role of nanoclay concentration and temperature.

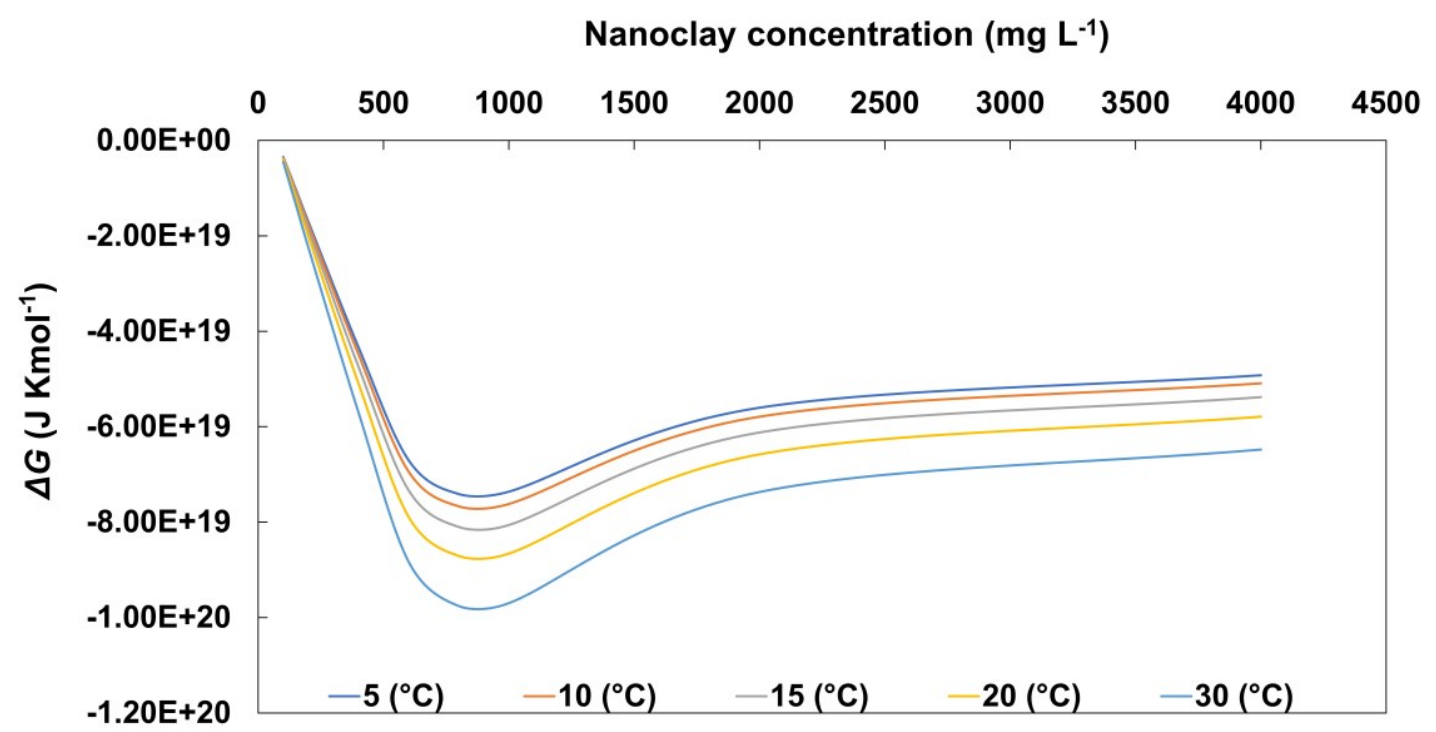

Figure 4-8. Calculated free energy of mixing versus nanoclay concentration at various temperature from 5 to $30^{\circ} \mathrm{C}$

\subsection{Dynamic simulation}

In order to have better understanding of this phenomena, a dynamic simulation analysis was further conducted. MD results revealed that the existence of nanoclay particles could enhance the detachment of the oil droplet from solid surface (Fig 4-9). The oil droplet had 
a contact angle of approximately $60.0^{\circ}$ initially. With the presence of nanoclay, the contact line receded, and the oil-substrate contact area decreased with elapsed time. In the early stage of the detachment, nanoclay particles start to penetrate into the oil-substrate interface as shown in Fig 4-9(c-f) and there was a wedge-shaped area formed between the oil droplet and the solid substrate. The spreading of the wedge area quickly separated the oil droplet from the solid surface. After that, the oil droplet was vertically elongated under the action of buoyancy and thermal disturbance and detached from the solid substrate. This process could be divided into three stages: (i) the contact line shrinks due to the decrease of interfacial tension; (ii) the diffusion of water disjoined the oil from the solid substrate in the vicinity of the contact line; and (iii) the contact radius became sufficiently small and the droplet detached (Kolev et al., 2003; Liu et al., 2012).

For the system in which the initial contact angle of the oil droplet was smaller than $90^{\circ}$, the imbalanced interfacial tension force would point in the direction impeding the detach of oil. To interpret the oil droplet detachment induced by the negatively charged nanoclay particles, several mechanisms were considered. Firstly, the presence of the nanoclay resulted in the reduction of the oil-substrate interfacial tension by reducing the contact angle. Consequently, the imbalanced interfacial tension force led to the contact line shrinkage. Besides, the induced charge on the solid surface made it exhibiting a tendency towards hydrophilicity (Yuan and Zhao, 2010), which was analogous to the contact angle change by electrowetting on dielectric. As can be seen in Fig 4-9(h-i), water molecules could penetrate into the area between oil droplet and substrate. Entropy negated by the arrangement of nanoparticles and charges also contributed to the detachment process (Sefiane et al., 2008; Wasan and Nikolov, 2003). 


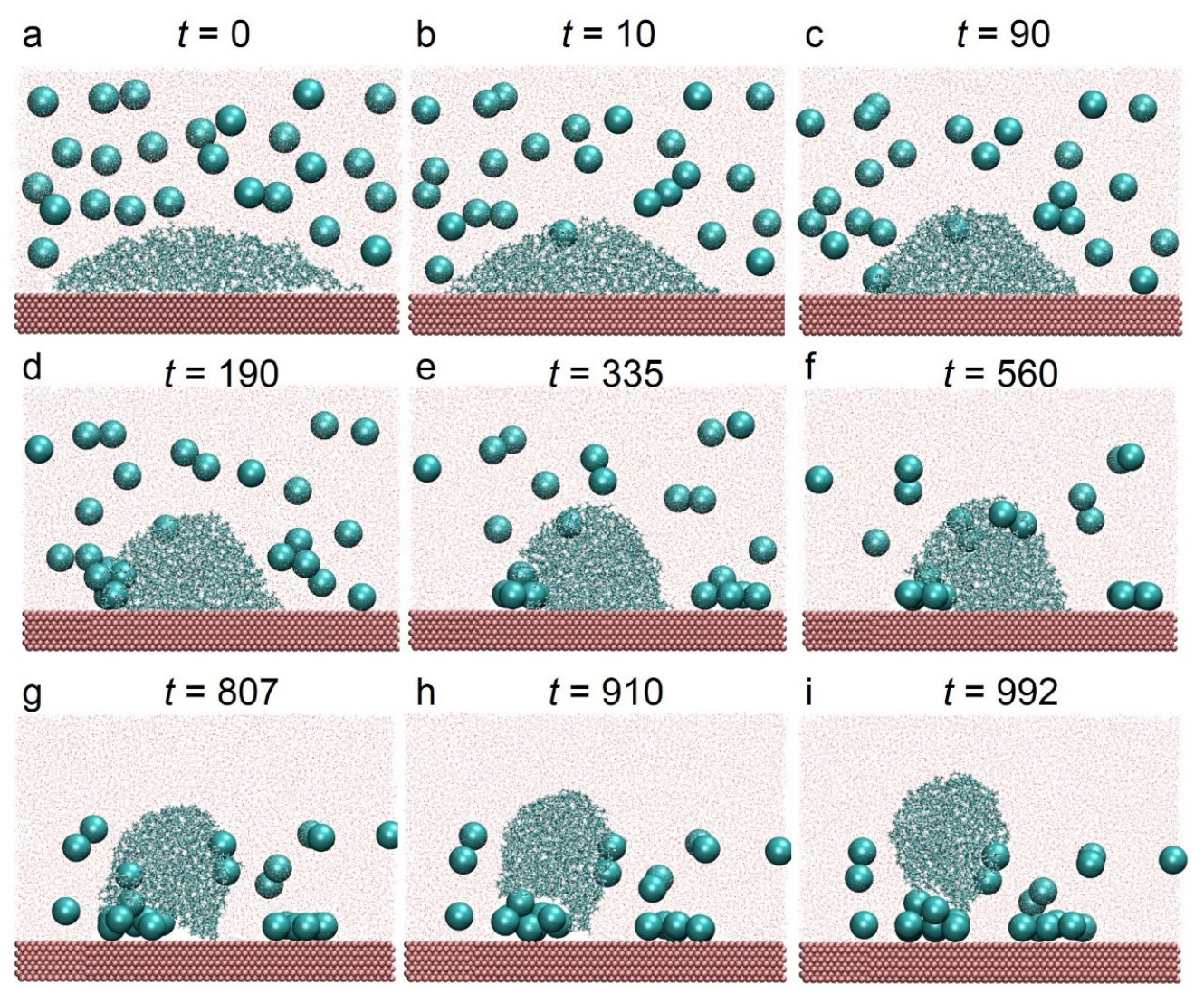

Figure 4-9. Snapshots of the spontaneous detachment of an oil droplet from a modeled solid substrate with nanoclay particles 


\section{CHAPTER 5. CONCLUSIONS}

\subsection{Summary}

This is the first study to comprehensively explore the effects of bentonite nanoclay on the oil behaviours in water-sand media from both experimental and modeling perspectives. Four factors including nanoclay concentration, temperature, salinity and $\mathrm{pH}$ have been studied. In general, the increasing nanoclay concentration resulted in the decrease in remaining oil on sand. Higher temperature and salinity were associated with less residual oil on sand in the presence of nanoclay. As $\mathrm{pH}$ varied between 4 to 10 , the less residual oil on sand was observed around neutral condition. By increasing $\mathrm{pH}$ from $\mathrm{pH}$ of 4 to 7, the remained oil on sand decreased considerably and from $\mathrm{pH}$ of 7 to 10 there was an increasing trend. The factorial analysis results indicated that the nanoclay concentration showed the most significant impact among these factors. For the two-level integrations, salinity * temperature presented the most significant effect on oil behavior. Miscibility modeling results showed an increasing temperature was favorable to the nanoclay miscibility. Moreover, the effect of nanoclay on oil behavior was further revealed through the dynamic simulation, in which it can be seen the nanoclay could penetrate into oil droplets and promote the detachment of oil from the solid substrate. The environmental processes in the shoreline impacted by oil spill are complicated. The results of this study can help understand the role of fine particle in the fate and transport of oil on shoreline. These findings can be used to support the risk assessment and response planning after oil spill. It is also expected to further investigate the oil behavior impacted by other shoreline characteristics. A brief highlight summary is as follows.

- The effects of nanoclay on oil behavior in sand-water system were studied.

- Oil behavior was impacted by nanoclay concentration, temperature, salinity and $\mathrm{pH}$.

- Factorial analysis was used to explore the interactions of different factors.

- Miscibility modeling and dynamic simulation were conducted to reveal the mechanism.

- The presence of nanoclay in oiled shoreline can be considered for risk assessment. 


\subsection{Recommendations for future study}

(1) Based on the previous research conducted to the field of nanoclays and its modified ones, it has a wide range of applications as a rheological control agent, barrier against gases in food packaging industries and playing a significant role in biomedical applications specially in drug delivery. The popularity of nanoclays is based on their specifications and specially its environmental application. The interesting environmental application of nanoclays has been seen in pollutant remediation from water (pharmaceutical, dye, heavy metal, pesticide and inorganic removal) and also air ( $\mathrm{H} 2 \mathrm{~S}$ removal and $\mathrm{CO}_{2}$ capturing).

(2) In this regard, modified nanoclays are promising materials for environmental applications, specifically environmental remediation but their biocompatible and ecocompliance when used in natural systems is not yet guaranteed. Since in many cases, we do not have sufficient data to conclude whether the modified nanoclay products are environmentally biocompatible, it is expected that future studies investigate this issue precisely.

(3) Since there is evidence of ecotoxicity caused by several modified nanoclays, the future studies would focus on the possibility of obtaining "low-toxic" or "eco-friendly" functionalised nanoclay products. Therefore, the concept of "bio compatibly modified nanoclays" should be advocated in the development of nanoclay-based materials designed for more effective remediation practices. Application of new generation environmentally friendly nanoclays should not result in the potential loss of living organisms at a contaminated site. In addition, since nanoclays are known as the specific particles with unique layered shape, nanosize, and well-defined structure, they have heterogeneous charge distribution and patchy interactions that enable the physical interactions of nanoclay with a range of biomolecules, polymers, and biological components.

(4) 2D nanoclay are an emerging class of biomaterials due to their unique ability to interact with a range of polymers, and macromolecules. Future studies will focus on a range of biomedical applications for nanoclay have been investigated, including orthopedic tissue engineering, wound healing, and haemostats, amongst others. 


\section{REFERENCES}

Abdelaal, A.M., 2004. Using a natural coagulant for treating wastewater. Eighth International Water Technology Conference 8, 781-792. https://doi.org/10.13140/RG.2.1.2193.5845

Adebajo, M.O., Frost, R.L., Kloprogge, J.T., Carmody, O., Kokot, S., 2003. Porous materials for oil spill cleanup: A review of synthesis and absorbing properties. Journal of Porous Materials. https://doi.org/10.1023/A:1027484117065

Adib, F., Bagreev, A., Bandosz, T.J., 2000. Analysis of the relationship between H 2 S removal capacity and surface properties of unimpregnated activated carbons. Environmental Science \& Technology 34, 686-692. https://doi.org/10.1021/es990341g

Aksu, Z., Balibek, E., 2010. Effect of salinity on metal-complex dye biosorption by Rhizopus arrhizus. Journal of Environmental Management 91, 1546-1555. https://doi.org/10.1016/j.jenvman.2010.02.026

Al-Hamadani, Y.A.J., Chu, K.H., Flora, J.R.V., Kim, D.H., Jang, M., Sohn, J., Joo, W., Yoon, Y., 2016. Sonocatalytical degradation enhancement for ibuprofen and sulfamethoxazole in the presence of glass beads and single-walled carbon nanotubes. $\begin{array}{llll}\text { Ultrasonics } & \text { Sonochemistry } & 32, & 440-448 \text {. }\end{array}$ https://doi.org/10.1016/j.ultsonch.2016.03.030

Ali, M.E.A., 2019. Preparation of graphene nanosheets by electrochemical exfoliation of a graphite-nanoclay composite electrode: Application for the adsorption of organic dyes. Colloids and Surfaces A: Physicochemical and Engineering Aspects 570, 107-116. https://doi.org/10.1016/j.colsurfa.2019.02.063

Almasri, D.A., Rhadfi, T., Atieh, M.A., McKay, G., Ahzi, S., 2018. High performance hydroxyiron modified montmorillonite nanoclay adsorbent for arsenite removal. 
Chemical Engineering Journal 335, 1-12. https://doi.org/10.1016/j.cej.2017.10.031

An, C., Huang, G., Yao, Y., Zhao, S., 2017. Emerging usage of electrocoagulation technology for oil removal from wastewater: A review. Science of the Total Environment. https://doi.org/10.1016/j.scitotenv.2016.11.062

Asadi, M., Montazer, M., 2013. Multi-functional polyester hollow fiber nonwoven fabric with using nano clay/nano TiO2/Polysiloxane composites. Journal of Inorganic and Organometallic Polymers and Materials 23, 1358-1367. https://doi.org/10.1007/s10904-013-9937-3

Asif, Z., Chen, Z., 2020. A life cycle based air quality modeling and decision support system (LCAQMS) for sustainable mining management. Journal of Environmental Informatics 35, 103-117. https://doi.org/10.3808/jei.201900406

Awasthi, A., Jadhao, P., Kumari, K., 2019. Clay nano-adsorbent: structures, applications and mechanism for water treatment. SN Applied Sciences 1, 1076. https://doi.org/10.1007/s42452-019-0858-9

Azha, S.F., Shahadat, M., Ismail, S., 2017. Acrylic polymer emulsion supported bentonite clay coating for the analysis of industrial dye. Dyes and Pigments 145, 550-560. https://doi.org/10.1016/j.dyepig.2017.05.009

Bandpei, A.M., Mohseni, S.M., Sheikhmohammadi, A., Sardar, M., Sarkhosh, M., Almasian, M., Avazpour, M., Mosallanejad, Z., Atafar, Z., Nazari, S., Rezaei, S., 2017. Optimization of arsenite removal by adsorption onto organically modified montmorillonite clay: Experimental \& theoretical approaches. Korean Journal of Chemical Engineering 34, 376-383. https://doi.org/10.1007/s11814-016-0287-z

Behroozi, M., Pakizeh, M., 2017. Study the effects of Cloisite15A nanoclay incorporation on the morphology and gas permeation properties of Pebax 2533 polymer. Journal of Applied Polymer Science 134, 45302. https://doi.org/10.1002/app.45302

Berendsen, H.J.C., Grigera, J.R., Straatsma, T.P., 1987. The missing term in effective pair 
potentials. The Journal of Physical Chemistry 91, 6269-6271. https://doi.org/10.1021/j100308a038

Bergaya, F., Lagaly, G., 2006. Chapter 1 general introduction: clays, clay minerals, and clay science, in: Developments in Clay Science. Elsevier, pp. 1-18. https://doi.org/10.1016/S1572-4352(05)01001-9

Berlin, S.-V., New, H., London, Y., Tokyo, P., Kong Barcelona, H., 1990. Health related effects of phyllosilicates, health related effects of phyllosilicates. Springer Berlin Heidelberg, Berlin, Heidelberg. https://doi.org/10.1007/978-3-642-75124-0

Bi, H., An, C., Chen, X., Owens, E., Lee, K., 2020. Investigation into the oil removal from sand using a surface washing agent under different environmental conditions. Journal of Environmental $\quad$ Management 111232. https://doi.org/10.1016/j.jenvman.2020.111232

Bodzek, M., Konieczny, K., 2011. Membrane techniques in the removal of inorganic anionic micropollutants from water environment state of the art. Archives of Environmental Protection 37, 15-19.

Bonto, M., Eftekhari, A.A., Nick, H.M., 2019. An overview of the oil-brine interfacial behavior and a new surface complexation model. Scientific Reports 9, 6072. https://doi.org/10.1038/s41598-019-42505-2

Brigatti, M.F., Galán, E., Theng, B.K.G., 2013. Structure and mineralogy of clay minerals, in: Developments in Clay Science. Elsevier B.V., pp. 21-81. https://doi.org/10.1016/B978-0-08-098258-8.00002-X

Cai, Q., Zhu, Z., Chen, B., Zhang, B., 2019. Oil-in-water emulsion breaking marine bacteria for demulsifying oily wastewater. Water Research 149, 292-301. https://doi.org/10.1016/j.watres.2018.11.023

Calabi Floody, M., Theng, B.K.G., Reyes, P., Mora, M.L., 2009. Natural nanoclays: applications and future trends - a Chilean perspective. Clay Minerals 44, 161-176. 
https://doi.org/10.1180/claymin.2009.044.2.161

Cao, Y., Zhang, B., Zhu, Z., Song, X., Cai, Q., Chen, B., Dong, G., Ye, X., 2020. Microbial eco-physiological strategies for salinity-mediated crude oil biodegradation. Science $\begin{array}{lllll}\text { of The Total } & \text { Environment } & 727, & 138723 .\end{array}$ https://doi.org/10.1016/j.scitotenv.2020.138723

Carmody, O., Frost, R., Xi, Y., Kokot, S., 2007. Adsorption of hydrocarbons on organoclays-Implications for oil spill remediation. Journal of Colloid and Interface Science 305, 17-24. https://doi.org/10.1016/j.jcis.2006.09.032

Chen, W., Liu, H.C., 2014. Adsorption of sulfate in aqueous solutions by organo-nano-clay: Adsorption equilibrium and kinetic studies. Journal of Central South University 21, 1974-1981. https://doi.org/10.1007/s11771-014-2145-7

Chen, Z., An, C., Yin, J., Owens, E., Lee, K., Zhang, K., Tian, X., 2021. Exploring the use of cellulose nanocrystal as surface-washing agent for oiled shoreline cleanup. Journal of Hazardous Materials 402, 123464. https://doi.org/10.1016/j.jhazmat.2020.123464

Chen, Zhikun, An, C., Boufadel, M., Owens, E., Chen, Zhi, Lee, K., Cao, Y., Cai, M., 2019. Use of surface-washing agents for the treatment of oiled shorelines: Research advancements, technical applications and future challenges. Chemical Engineering Journal. https://doi.org/10.1016/j.cej.2019.123565

Chowdhury, S., Balasubramanian, R., 2014. Recent advances in the use of graphene-family nanoadsorbents for removal of toxic pollutants from wastewater. Advances in Colloid and Interface Science. https://doi.org/10.1016/j.cis.2013.12.005

Choy, J.H., Choi, S.J., Oh, J.M., Park, T., 2007. Clay minerals and layered double hydroxides for novel biological applications. Applied Clay Science 36, 122-132. https://doi.org/10.1016/j.clay.2006.07.007

Chu, K.H., Fathizadeh, M., Yu, M., Flora, J.R.V., Jang, A., Jang, M., Park, C.M., Yoo, S.S., Her, N., Yoon, Y., 2017. Evaluation of removal mechanisms in a graphene oxide- 
coated ceramic ultrafiltration membrane for retention of natural organic matter, pharmaceuticals, and inorganic salts. ACS Applied Materials and Interfaces 9, 4036940377. https://doi.org/10.1021/acsami.7b14217

Chu, K.H., Huang, Y., Yu, M., Her, N., Flora, J.R.V., Park, C.M., Kim, S., Cho, J., Yoon, Y., 2016. Evaluation of humic acid and tannic acid fouling in graphene oxide-coated ultrafiltration membranes. ACS Applied Materials and Interfaces 8, 22270-22279. https://doi.org/10.1021/acsami.6b08020

Churchley, J.H., 1994. Removal of dyewaste colour from sewage effluent - The use of a full scale ozone plant, in: Water Science and Technology. Pergamon Press Inc, pp. 275-284. https://doi.org/10.2166/wst.1994.0120

Churchman, G.J., Gates, W.P., Theng, B.K.G., Yuan, G., 2006. Chapter 11.1 Clays and clay minerals for pollution control, in: Developments in Clay Science. pp. 625-675. https://doi.org/10.1016/S1572-4352(05)01020-2

Cleary, D.F.R., Polónia, A.R.M., de Voogd, N.J., 2018. Bacterial communities inhabiting the sponge biemna fortis, Sediment and Water in Marine Lakes and the Open Sea. Microbial Ecology 76, 610-624. https://doi.org/10.1007/s00248-018-1156-6

Coro, E., Laha, S., 2001. Color removal in groundwater through the enhanced softening process. Water Research 35, 1851-1854. https://doi.org/10.1016/S00431354(00)00440-1

Crespo, J.G., Velizarov, S., Reis, M.A., 2004. Membrane bioreactors for the removal of anionic micropollutants from drinking water. Current Opinion in Biotechnology 15, 463-468. https://doi.org/10.1016/j.copbio.2004.07.001

Drummy, L.F., Jones, S.E., Pandey, R.B., Farmer, B.L., Vaia, R.A., Naik, R.R., 2010. Bioassembled layered silicate-metal nanoparticle hybrids. ACS Applied Materials and Interfaces 2, 1492-1498. https://doi.org/10.1021/am1001184

El Haouti, R., Ouachtak, H., El Guerdaoui, A., Amedlous, A., Amaterz, E., Haounati, R., 
Addi, A.A., Akbal, F., El Alem, N., Taha, M.L., 2019. Cationic dyes adsorption by NaMontmorillonite Nano Clay: Experimental study combined with a theoretical investigation using DFT-based descriptors and molecular dynamics simulations. $\begin{array}{lllll}\text { Journal of } & \text { Molecular } & \text { Liquids } & 290, & 11139 .\end{array}$ https://doi.org/10.1016/j.molliq.2019.111139

Eslinger, E., Pevear, D., 1988. Clay minerals for petroleum geologists and engineers, Clay minerals for petroleum geologists and engineers. SEPM (Society for Sedimentary Geology). https://doi.org/10.2110/scn.88.22

Fakhrullina, G.I., Akhatova, F.S., Lvov, Y.M., Fakhrullin, R.F., 2015. Toxicity of halloysite clay nanotubes in vivo: A Caenorhabditis elegans study. Environmental Science: Nano 2, 54-59. https://doi.org/10.1039/c4en00135d

Fan, F., Zhang, B., Liu, J., Cai, Q., Lin, W., Chen, B., 2020. Towards sulfide removal and sulfate reducing bacteria inhibition: Function of biosurfactants produced by indigenous isolated nitrate reducing bacteria. Chemosphere 238, 124655. https://doi.org/10.1016/j.chemosphere.2019.124655

Flory, P.J., 1942. Themodynamics of high polymer solutions. The Journal of Chemical Physics 10, 51-61. https://doi.org/10.1063/1.1723621

Foorginezhad, S., Zerafat, M.M., 2017. Microfiltration of cationic dyes using nano-clay membranes. Ceramics International 43, 15146-15159. https://doi.org/10.1016/j.ceramint.2017.08.045

Fradique, R., Correia, T.R., Miguel, S.P., de Sá, K.D., Figueira, D.R., Mendonça, A.G., Correia, I.J., 2016. Production of new 3D scaffolds for bone tissue regeneration by rapid prototyping. Journal of Materials Science: Materials in Medicine 27, 1-14. https://doi.org/10.1007/s10856-016-5681-x

Fu, L., Datta, K.K.R., Spyrou, K., Qi, G., Sardar, A., Khader, M.M., Zboril, R., Giannelis, E.P., 2017. Phyllosilicate nanoclay-based aqueous nanoparticle sorbent for $\mathrm{CO} 2$ 
capture at ambient conditions. Applied Materials Today 9, 451-455. https://doi.org/10.1016/j.apmt.2017.09.009

Garrido-Ramírez, E.G., Theng, B.K.G., Mora, M.L., 2010. Clays and oxide minerals as catalysts and nanocatalysts in Fenton-like reactions - A review. Applied Clay Science. https://doi.org/10.1016/j.clay.2009.11.044

Gatica, J.M., Vidal, H., 2010. Non-cordierite clay-based structured materials for environmental applications. Journal of Hazardous Materials. https://doi.org/10.1016/j.jhazmat.2010.05.041

Ghodke, S., Sonawane, S., Gaikawad, R., Mohite, K.C., 2012. TIO 2/Nanoclay nanocomposite for phenol degradation in sonophotocatalytic reactor. Canadian Journal of Chemical Engineering 90, 1153-1159. https://doi.org/10.1002/cjce.20630

Gilman, J., 1999. Flammability and thermal stability studies of polymer layered-silicate (clay) nanocomposites. Applied Clay Science 15, 31-49. https://doi.org/10.1016/S0169-1317(99)00019-8

Goettler, L.A., Lee, K.Y., Thakkar, H., 2007. Layered silicate reinforced polymer nanocomposites: Development and applications. Polymer Reviews 47, 291-317. https://doi.org/10.1080/15583720701271328

Guo, F., Aryana, S., 2016. An experimental investigation of nanoparticle-stabilized CO2 foam used in enhanced oil recovery. Fuel 186, 430-442. https://doi.org/10.1016/j.fuel.2016.08.058

Guo, F., Aryana, S., Han, Y., Jiao, Y., 2018. A review of the synthesis and applications of polymer-nanoclay composites. Applied Sciences (Switzerland). https://doi.org/10.3390/app8091696

Gürses, A., 2016. Introduction to polymer-clay nanocomposites, Introduction to PolymerClay Nanocomposites. https://doi.org/10.1201/b18716

Helle, I., Ahtiainen, H., Luoma, E., Hänninen, M., Kuikka, S., 2015. A probabilistic 
approach for a cost-benefit analysis of oil spill management under uncertainty: A Bayesian network model for the Gulf of Finland. Journal of Environmental Management 158, 122-132. https://doi.org/10.1016/j.jenvman.2015.04.042

Heo, J., Boateng, L.K., Flora, J.R.V., Lee, H., Her, N., Park, Y.G., Yoon, Y., 2013. Comparison of flux behavior and synthetic organic compound removal by forward osmosis and reverse osmosis membranes. Journal of Membrane Science 443, 69-82. https://doi.org/10.1016/j.memsci.2013.04.063

Hou, N., Xia, Y., Wang, X., Liu, Huaiwei, Liu, Honglei, Xun, L., 2018. H2S biotreatment with sulfide-oxidizing heterotrophic bacteria. Biodegradation 29, 511-524. https://doi.org/10.1007/s10532-018-9849-6

Houtman, J., Maisanaba, S., Puerto, M., Gutiérrez-Praena, D., Jordá, M., Aucejo, S., Jos, A., 2014. Toxicity assessment of organomodified clays used in food contact materials on human target cell lines. Applied Clay Science 90, 150-158. https://doi.org/10.1016/j.clay.2014.01.009

Huggins, M.L., 1942. Some properties of solutions of long-chain compounds. Journal of Physical Chemistry 46, 151-158. https://doi.org/10.1021/j150415a018

Hughes, M.N., Centelles, M.N., Moore, K.P., 2009. Making and working with hydrogen sulfide. The chemistry and generation of hydrogen sulfide in vitro and its measurement in vivo: A review. Free Radical Biology and Medicine. https://doi.org/10.1016/j.freeradbiomed.2009.09.018

Humphrey, W., Dalke, A., Schulten, K., 1996. VMD: Visual molecular dynamics. Journal of Molecular Graphics 14, 33-38. https://doi.org/10.1016/0263-7855(96)00018-5

Ibrahim, S., Wang, S., Ang, H.M., 2010. Removal of emulsified oil from oily wastewater using agricultural waste barley straw. Biochemical Engineering Journal 49, 78-83. https://doi.org/10.1016/j.bej.2009.11.013

Im, J.K., Heo, J., Boateng, L.K., Her, N., Flora, J.R.V., Yoon, J., Zoh, K.D., Yoon, Y., 2013. 
Ultrasonic degradation of acetaminophen and naproxen in the presence of singlewalled carbon nanotubes. Journal of Hazardous Materials 254-255, 284-292. https://doi.org/10.1016/j.jhazmat.2013.04.001

Isoda, K., Nagata, R., Hasegawa, T., Taira, Y., Taira, I., Shimizu, Y., Isama, K., Nishimura, T., Ishida, I., 2017. Hepatotoxicity and drug/chemical interaction toxicity of nanoclay particles in mice. Nanoscale Research Letters 12. https://doi.org/10.1186/s11671-017$1956-5$

J. Ordieres-Meré, J. Ouarzazi, B. El Johra, B.G., 2020. Predicting ground level ozone in marrakesh by machine-learning techniques. Journal of Environmental Informatics. https://doi.org/10.3808/jei.202000437

Jada, A., Ait Akbour, R., Douch, J., 2006. Surface charge and adsorption from water onto quartz sand of humic acid. Chemosphere 64, 1287-1295. https://doi.org/10.1016/j.chemosphere.2005.12.063

Janer, G., Fernández-Rosas, E., Mas Del Molino, E., González-Gálvez, D., Vilar, G., López-Iglesias, C., Ermini, V., Vázquez-Campos, S., 2014. In vitro toxicity of functionalised nanoclays is mainly driven by the presence of organic modifiers. Nanotoxicology 8, 279-294. https://doi.org/10.3109/17435390.2013.776123

Janssen, A.J.H., Lens, P.N.L., Stams, A.J.M., Plugge, C.M., Sorokin, D.Y., Muyzer, G., Dijkman, H., Van Zessen, E., Luimes, P., Buisman, C.J.N., 2009. Application of bacteria involved in the biological sulfur cycle for paper mill effluent purification. Science of the Total Environment 407, 1333-1343. https://doi.org/10.1016/j.scitotenv.2008.09.054

Jeong, I.S., Lee, S.R., Song, I., Kang, S.H., 2019. A biological monitoring method based on the response behavior of caenorhabditis elegans to chemicals in water. Journal of Environmental Informatics 33, 47-55. https://doi.org/10.3808/jei.201700356

Jeswani, H.K., Gujba, H., Brown, N.W., Roberts, E.P.L., Azapagic, A., 2015. Removal of 
organic compounds from water: Life cycle environmental impacts and economic costs of the Arvia process compared to granulated activated carbon. Journal of Cleaner Production 89, 203-213. https://doi.org/10.1016/j.jclepro.2014.11.017

Jlassi, K., Krupa, I., Chehimi, M.M., 2017. Overview, in: Clay-Polymer Nanocomposites. Elsevier, pp. 1-28. https://doi.org/10.1016/B978-0-323-46153-5.00001-X

Joseph, L., Jun, B.M., Flora, J.R.V., Park, C.M., Yoon, Y., 2019. Removal of heavy metals from water sources in the developing world using low-cost materials: A review. Chemosphere. https://doi.org/10.1016/j.chemosphere.2019.04.198

Jung, C., Park, J., Lim, K.H., Park, S., Heo, J., Her, N., Oh, J., Yun, S., Yoon, Y., 2013. Adsorption of selected endocrine disrupting compounds and pharmaceuticals on activated biochars. Journal of Hazardous Materials 263, 702-710. https://doi.org/10.1016/j.jhazmat.2013.10.033

Jung, C., Son, A., Her, N., Zoh, K.D., Cho, J., Yoon, Y., 2015. Removal of endocrine disrupting compounds, pharmaceuticals, and personal care products in water using carbon nanotubes: A review. Journal of Industrial and Engineering Chemistry. https://doi.org/10.1016/j.jiec.2014.12.035

Kabil, O., Banerjee, R., 2010. Redox biochemistry of hydrogen sulfide. Journal of Biological Chemistry 285, 21903-21907. https://doi.org/10.1074/jbc.R110.128363

Khajeh, M., Ghaemi, A., 2020. Exploiting response surface methodology for experimental modeling and optimization of $\mathrm{CO} 2$ adsorption onto $\mathrm{NaOH}$-modified nanoclay montmorillonite. Journal of Environmental Chemical Engineering 8, 103663. https://doi.org/10.1016/j.jece.2020.103663

Khatoon, N., Chu, M.Q., Zhou, C.H., 2020. Nanoclay-based drug delivery systems and their therapeutic potentials. Journal of Materials Chemistry B. https://doi.org/10.1039/d0tb01031f

Kiliaris, P., Papaspyrides, C.D., 2010. Polymer/layered silicate (clay) nanocomposites: An 
overview of flame retardancy. Progress in Polymer Science (Oxford). https://doi.org/10.1016/j.progpolymsci.2010.03.001

Kim, S., Park, C.M., Jang, M., Son, A., Her, N., Yu, M., Snyder, S., Kim, D.H., Yoon, Y., 2018. Aqueous removal of inorganic and organic contaminants by graphene-based $\begin{array}{llll}\text { nanoadsorbents: } & \text { A } & \text { review. } & \text { Chemosphere. }\end{array}$ https://doi.org/10.1016/j.chemosphere.2018.09.033

Kolev, V.L., Kochijashky, I.I., Danov, K.D., Kralchevsky, P.A., Broze, G., Mehreteab, A., 2003. Spontaneous detachment of oil drops from solid substrates: Governing factors. Journal of Colloid and Interface Science 257, 357-363. https://doi.org/10.1016/S0021-9797(02)00052-8

Kong, F.Y., Gu, S.X., Li, W.W., Chen, T.T., Xu, Q., Wang, W., 2014. A paper disk equipped with graphene/polyaniline/Au nanoparticles/glucose oxidase biocomposite modified screen-printed electrode: Toward whole blood glucose determination. Biosensors and Bioelectronics 56, 77-82. https://doi.org/10.1016/j.bios.2013.12.067

Konieczny, K., Bodzek, M., 2007. Wykorzystanie technik membranowych w uzdatnianiu wody do picia : stan wiedzy. Instal nr 4, 58-61.

Kryuchkova, M., Danilushkina, A., Lvov, Y., Fakhrullin, R., 2016. Evaluation of toxicity of nanoclays and graphene oxide: in vivo A Paramecium caudatum study. Environmental Science: Nano 3, 442-452. https://doi.org/10.1039/c5en00201j

Le Floch, S., Guyomarch, J., Merlin, F.-X., Stoffyn-Egli, P., Dixon, J., Lee, K., 2002. The influence of salinity on oil-mineral aggregate formation. Spill Science \& Technology Bulletin 8, 65-71. https://doi.org/10.1016/S1353-2561(02)00124-X

Leodopoulos, C., Doulia, D., Gimouhopoulos, K., 2015. Adsorption of cationic dyes onto bentonite. Separation \& Purification Reviews 44, 74-107. https://doi.org/10.1080/15422119.2013.823622

Lerner, U., Hirshfeld, O., Fishbasin, B., 2019. Optimal deployment of a heterogeneous air 
quality sensor network. Journal of Environmental Informatics 34, 99-107. https://doi.org/10.3808/jei.201800399

Leszczyńska, A., Njuguna, J., Pielichowski, K., Banerjee, J.R., 2007 a. Polymer/montmorillonite nanocomposites with improved thermal properties. Part I. Factors influencing thermal stability and mechanisms of thermal stability improvement. Thermochimica Acta. https://doi.org/10.1016/j.tca.2006.11.002

Leszczyńska, A., Njuguna, J., Pielichowski, K., Banerjee, J.R., $2007 b$. Polymer/montmorillonite nanocomposites with improved thermal properties. Part II. Thermal stability of montmorillonite nanocomposites based on different polymeric matrixes. Thermochimica Acta. https://doi.org/10.1016/j.tca.2006.11.003

Li, X., Fan, F., Zhang, B., Zhang, K., Chen, B., 2018. Biosurfactant enhanced soil bioremediation of petroleum hydrocarbons: Design of experiments (DOE) based system optimization and phospholipid fatty acid (PLFA) based microbial community analysis. International Biodeterioration and Biodegradation 132, 216-225. https://doi.org/10.1016/j.ibiod.2018.04.009

Liang, S., Fang, T., Xiong, W., Ding, B., Yan, Y., Zhang, J., 2019. Oil detachment by modified nanoparticles: A molecular dynamics simulation study. Computational Materials Science 170, 109177. https://doi.org/10.1016/j.commatsci.2019.109177

Lim, M.W., Lau, E. Von, Poh, P.E., 2016. A comprehensive guide of remediation technologies for oil contaminated soil — Present works and future directions. Marine Pollution Bulletin 109, 14-45. https://doi.org/10.1016/j.marpolbul.2016.04.023

Lindenschmidt, K.E., Rokaya, P., 2019. A Stochastic hydraulic modelling approach to determining the probable maximum staging of ice-jam floods. Journal of Environmental Informatics 34, 45-54. https://doi.org/10.3808/jei.201900416

Liu, B., Chen, B., Zhang, B., Song, X., Zeng, G., Lee, K., 2021. Photocatalytic ozonation of offshore produced water by $\mathrm{TiO} 2$ nanotube arrays coupled with UV-LED 
irradiation. Journal of Hazardous Materials 402, 123456. https://doi.org/10.1016/j.jhazmat.2020.123456

Liu, Q., Yuan, S., Yan, H., Zhao, X., 2012. Mechanism of oil detachment from a silica surface in aqueous surfactant solutions: Molecular dynamics simulations. Journal of Physical Chemistry B 116, 2867-2875. https://doi.org/10.1021/jp2118482

Liu, Y., Huang, G., An, C., Chen, X., Zhang, P., Feng, R., Xiong, W., 2020. Use of Nano$\mathrm{TiO} 2$ self-assembled flax fiber as a new initiative for immiscible oil/water separation. Journal of Cleaner Production 249. https://doi.org/10.1016/j.jclepro.2019.119352

Lordan, S., Kennedy, J.E., Higginbotham, C.L., 2011. Cytotoxic effects induced by unmodified and organically modified nanoclays in the human hepatic HepG2 cell line. Journal of Applied Toxicology 31, 27-35. https://doi.org/10.1002/jat.1564

Lucas, Z., MacGregor, C., 2006. Characterization and source of oil contamination on the beaches and seabird corpses, Sable Island, Nova Scotia, 1996-2005. Marine Pollution Bulletin 52, 778-789. https://doi.org/10.1016/j.marpolbul.2005.11.023

M. Roberto, M., A. Christofoletti, C., 2020. How to assess nanomaterial toxicity? An environmental and human health approach, in: Nanomaterials - Toxicity, Human Health and Environment. IntechOpen. https://doi.org/10.5772/intechopen. 88970

Maisanaba, S., Gutiérrez-Praena, D., Pichardo, S., Moreno, F.J., Jordá, M., Cameán, A.M., Aucejo, S., Jos, Á., 2014. Toxic effects of a modified montmorillonite clay on the human intestinal cell line Caco-2. Journal of Applied Toxicology 34, 714-725. https://doi.org/10.1002/jat.2945

Maisanaba, S., Puerto, M., Pichardo, S., Jordá, M., Moreno, F.J., Aucejo, S., Jos, Á., 2013. In vitro toxicological assessment of clays for their use in food packaging applications. Food and Chemical Toxicology 57, 266-275. https://doi.org/10.1016/j.fct.2013.03.043

Malaviya, P., Singh, A., 2011. Physicochemical technologies for remediation of chromium- 
containing waters and wastewaters. Critical Reviews in Environmental Science and Technology 41, 1111-1172. https://doi.org/10.1080/10643380903392817

Marsh, K.N., 2007. The measurement of thermodynamic excess functions of binary liquid mixtures. pp. 1-45. https://doi.org/10.1039/9781847555830-00001

Martin, R.T., 1991. Report of the clay minerals society nomenclature committee: Revised classification of clay materials. Clays and Clay Minerals 39, 333-335. https://doi.org/10.1346/CCMN.1991.0390315

Martinez, L., Andrade, R., Birgin, E.G., Martínez, J.M., 2009. PACKMOL: A package for building initial configurations for molecular dynamics simulations. Journal of Computational Chemistry 30, 2157-2164. https://doi.org/10.1002/jcc.21224

Matei, E., Rapa, M., Covaliu, C.I., Predescu, A.M., Turcanu, A., Predescu, C., Ignat, D., Vlad, G., 2020. Sodium alginate-cellulose-nano-clay composite adsorbent applied for lead removal from wastewater. Revista de Chimie 71, 416-424. https://doi.org/10.37358/RC.20.3.8015

Mekhamer, W.K., 2010. The colloidal stability of raw bentonite deformed mechanically by ultrasound. Journal of Saudi Chemical Society 14, 301-306. https://doi.org/10.1016/j.jscs.2010.04.013

Mestre, A.S., Pinto, M.L., Pires, J., Nogueira, J.M.F., Carvalho, A.P., 2010. Effect of solution $\mathrm{pH}$ on the removal of clofibric acid by cork-based activated carbons. Carbon 48, 972-980. https://doi.org/10.1016/j.carbon.2009.11.013

Mohanadhas, B., Govindarajan, S.K., 2018. Modeling the sensitivity of hydrogeological parameters associated with leaching of uranium transport in an unsaturated porous medium. Environmental Engineering Research 23, 462-473. https://doi.org/10.4491/eer.2017.113

Molnes, S.N., Torrijos, I.P., Strand, S., Paso, K.G., Syverud, K., 2016. Sandstone injectivity and salt stability of cellulose nanocrystals (CNC) dispersions-Premises for use of 
$\mathrm{CNC}$ in enhanced oil recovery. Industrial Crops and Products 93, 152-160. https://doi.org/10.1016/j.indcrop.2016.03.019

Morozov, G., Breus, V., Nekludov, S., Breus, I., 2014. Sorption of volatile organic compounds and their mixtures on montmorillonite at different humidity. Colloids and Surfaces A: Physicochemical and Engineering Aspects 454, 159-171. https://doi.org/10.1016/j.colsurfa.2014.03.104

Mosselhy, D.A., El-Aziz, M.A., Hanna, M., Ahmed, M.A., Husien, M.M., Feng, Q., 2015. Comparative synthesis and antimicrobial action of silver nanoparticles and silver nitrate. Journal of Nanoparticle Research 17, 1-10. https://doi.org/10.1007/s11051015-3279-8

Motta, A.T., Yilmazbayhan, A., da Silva, M.J.G., Comstock, R.J., Was, G.S., Busby, J.T., Gartner, E., Peng, Q., Jeong, Y.H., Park, J.Y., 2007. Zirconium alloys for supercritical water reactor applications: Challenges and possibilities. Journal of Nuclear Materials 371, 61-75. https://doi.org/10.1016/j.jnucmat.2007.05.022

Mousavi, S.M., Hashemi, S.A., Salahi, S., Hosseini, M., Amani, A.M., Babapoor, A., 2018. Development of clay nanoparticles toward bio and medical applications, in: Current Topics in the Utilization of Clay in Industrial and Medical Applications. InTech. https://doi.org/10.5772/intechopen.77341

Murphy, E.J., Roberts, E., Anderson, D.K., Horrocks, L.A., 1993. Cytotoxicity of aluminum silicates in primary neuronal cultures. Neuroscience 57, 483-490. https://doi.org/10.1016/0306-4522(93)90081-P

Murphy, M.P., 2009. How mitochondria produce reactive oxygen species. Biochemical Journal 417, 1-13. https://doi.org/10.1042/BJ20081386

Nam, S.W., Jung, C., Li, H., Yu, M., Flora, J.R.V., Boateng, L.K., Her, N., Zoh, K.D., Yoon, Y., 2015a. Adsorption characteristics of diclofenac and sulfamethoxazole to graphene oxide in aqueous solution. Chemosphere 136, 20-26. 
https://doi.org/10.1016/j.chemosphere.2015.03.061

Nam, S.W., Yoon, Y., Choi, D.J., Zoh, K.D., 2015b. Degradation characteristics of metoprolol during UV/chlorination reaction and a factorial design optimization. Journal of Hazardous Materials 285, 453-463. https://doi.org/10.1016/j.jhazmat.2014.11.052

Naqvi, S., Kumar, V., Gopinath, P., 2018. Nanomaterial toxicity: A challenge to end users, in: Applications of Nanomaterials. Elsevier Ltd., pp. 315-343. https://doi.org/10.1016/b978-0-08-101971-9.00012-0

Newman, D.J., Cragg, G.M., 2007. Natural products as sources of new drugs over the last 25 years. Journal of Natural Products. https://doi.org/10.1021/np068054v

Nicholls, P., Kim, J.K., 1982. Sulphide as an inhibitor and electron donor for the cytochrome c oxidase system. Canadian journal of biochemistry 60, 613-623. https://doi.org/10.1139/o82-076

Niriella, D., Carnahan, R.P., 2006. Comparison study of zeta potential values of bentonite in salt solutions. Journal of Dispersion Science and Technology 27, 123-131. https://doi.org/10.1081/DIS-200066860

Njuguna, J., Pielichowski, K., Zhu, H., 2014. Health and environmental safety of nanomaterials: Polymer nancomposites and other materials containing nanoparticles, Health and Environmental Safety of Nanomaterials: Polymer Nancomposites and Other Materials Containing Nanoparticles. Woodhead Publishing, Cambridge. https://doi.org/10.1533/9780857096678

Ormad, M.P., Miguel, N., Claver, A., Matesanz, J.M., Ovelleiro, J.L., 2008. Pesticides removal in the process of drinking water production. Chemosphere 71, 97-106. https://doi.org/10.1016/j.chemosphere.2007.10.006

Owens, E.H., Taylor, E., Humphrey, B., 2008. The persistence and character of stranded oil on coarse-sediment beaches. Marine Pollution Bulletin 56, 14-26. 
https://doi.org/10.1016/j.marpolbul.2007.08.020

Ozekmekci, M., Salkic, G., Fellah, M.F., 2015. Use of zeolites for the removal of H2S: A mini-review. Fuel Processing Technology. https://doi.org/10.1016/j.fuproc.2015.08.015

Park, C.M., Han, J., Chu, K.H., Al-Hamadani, Y.A.J., Her, N., Heo, J., Yoon, Y., 2017 a. Influence of solution $\mathrm{pH}$, ionic strength, and humic acid on cadmium adsorption onto activated biochar: Experiment and modeling. Journal of Industrial and Engineering Chemistry 48, 186-193. https://doi.org/10.1016/j.jiec.2016.12.038

Park, C.M., Heo, J., Wang, D., Su, C., Yoon, Y., 2018. Heterogeneous activation of persulfate by reduced graphene oxide-elemental silver/magnetite nanohybrids for the oxidative degradation of pharmaceuticals and endocrine disrupting compounds in water. Applied Catalysis B: Environmental 225, 91-99. https://doi.org/10.1016/j.apcatb.2017.11.058

Park, C.M., Heo, J., Yoon, Y., 2017b. Oxidative degradation of bisphenol A and 17 $\alpha$-ethinyl estradiol by Fenton-like activity of silver nanoparticles in aqueous solution. Chemosphere 168, 617-622. https://doi.org/10.1016/j.chemosphere.2016.11.016

Park, J.S., Her, N., Oh, J., Yoon, Y., 2011. Sonocatalytic degradation of bisphenol A and 17a-ethinyl estradiol in the presence of stainless steel wire mesh catalyst in aqueous solution. Separation and Purification Technology 78, 228-236. https://doi.org/10.1016/j.seppur.2011.02.007

Plakas, K. V., Karabelas, A.J., 2012. Removal of pesticides from water by NF and RO membranes - A review. Desalination 287, 255-265. https://doi.org/10.1016/j.desal.2011.08.003

Plimpton, S., 1995. Fast parallel algorithms for short-range molecular dynamics. Journal of Computational Physics 117, 1-19. https://doi.org/10.1006/jcph.1995.1039

Rafati, L., Ehrampoush, M.H., Rafati, A.A., Mokhtari, M., Mahvi, A.H., 2018. Removal of 
ibuprofen from aqueous solution by functionalized strong nano-clay composite adsorbent: kinetic and equilibrium isotherm studies. International Journal of Environmental Science and Technology 15, 513-524. https://doi.org/10.1007/s13762017-1393-0

Rafati, L., Ehrampoush, M.H., Rafati, A.A., Mokhtari, M., Mahvi, A.H., 2016. Modeling of adsorption kinetic and equilibrium isotherms of naproxen onto functionalized nanoclay composite adsorbent. Journal of Molecular Liquids 224, 832-841. https://doi.org/10.1016/j.molliq.2016.10.059

Rai, M., Biswas, J.K., 2019. Nanomaterials : ecotoxicity, safety, and public perception. Springer.

Ramadass, K., Sathish, C.I., Mariaruban, S., Kothandam, G., Joseph, S., Singh, G., Kim, S., Cha, W., Karakoti, A., Belperio, T., Yi, J.B., Vinu, A., 2020. Carbon nanoflakes and nanotubes from halloysite nanoclays and their superior performance in $\mathrm{CO} 2$ capture and energy storage. ACS Applied Materials and Interfaces 12, 11922-11933. https://doi.org/10.1021/acsami.9b21510

Ramanayaka, S., Sarkar, B., Cooray, A.T., Ok, Y.S., Vithanage, M., 2020. Halloysite nanoclay supported adsorptive removal of oxytetracycline antibiotic from aqueous media. Journal of Hazardous Materials 384, 121301. https://doi.org/10.1016/j.jhazmat.2019.121301

Ren, X., Zeng, G., Tang, L., Wang, J., Wan, J., Feng, H., Song, B., Huang, C., Tang, X., 2018a. Effect of exogenous carbonaceous materials on the bioavailability of organic pollutants and their ecological risks. Soil Biology and Biochemistry. https://doi.org/10.1016/j.soilbio.2017.09.027

Ren, X., Zeng, G., Tang, L., Wang, J., Wan, J., Liu, Y., Yu, J., Yi, H., Ye, S., Deng, R., 2018b. Sorption, transport and biodegradation - An insight into bioavailability of persistent organic pollutants in soil. Science of the Total Environment. 
https://doi.org/10.1016/j.scitotenv.2017.08.089

Roth, E.A., Agarwal, S., Gupta, R.K., 2013. Nanoclay-based solid sorbents for CO2 capture. Energy and Fuels 27, 4129-4136. https://doi.org/10.1021/ef302017m

Salam, M.A., Kosa, S.A., Al-Beladi, A.A., 2017. Application of nanoclay for the adsorptive removal of Orange $\mathrm{G}$ dye from aqueous solution. Journal of Molecular Liquids 241, 469-477. https://doi.org/10.1016/j.molliq.2017.06.055

Salem, I.A., El-Maazawi, M.S., 2000. Kinetics and mechanism of color removal of methylene blue with hydrogen peroxide catalyzed by some supported alumina surfaces. Chemosphere 41, 1173-1180. https://doi.org/10.1016/S00456535(00)00009-6

Sarbatly, R., Krishnaiah, D., Kamin, Z., 2016. A review of polymer nanofibres by electrospinning and their application in oil-water separation for cleaning up marine oil spills. Marine Pollution Bulletin. https://doi.org/10.1016/j.marpolbul.2016.03.037

Sefiane, K., Skilling, J., MacGillivray, J., 2008. Contact line motion and dynamic wetting of nanofluid solutions. Advances in Colloid and Interface Science. https://doi.org/10.1016/j.cis.2007.12.003

Serrano, M.C., Gutiérrez, M.C., Del Monte, F., 2014. Role of polymers in the design of 3D carbon nanotube-based scaffolds for biomedical applications. Progress in Polymer Science. https://doi.org/10.1016/j.progpolymsci.2014.02.004

Shabeer, T.P.A., Saha, A., Gajbhiye, V.T., Gupta, S., Manjaiah, K.M., Varghese, E., 2015. Exploitation of nano-bentonite, nano-halloysite and organically modified nanomontmorillonite as an adsorbent and coagulation aid for the removal of multipesticides from water: A sorption modelling approach. Water, Air, and Soil Pollution 226. https://doi.org/10.1007/s11270-015-2331-8

Shen, J., Huang, G., An, C., Zhao, S., Rosendahl, S., 2017. Immobilization of tetrabromobisphenol A by pinecone-derived biochars at solid-liquid interface: 
Synchrotron-assisted analysis and role of inorganic fertilizer ions. Chemical Engineering Journal 321, 346-357. https://doi.org/10.1016/j.cej.2017.03.138

Shirsath, S.R., Hage, A.P., Zhou, M., Sonawane, S.H., Ashokkumar, M., 2011. Ultrasound assisted preparation of nanoclay Bentonite-FeCo nanocomposite hybrid hydrogel: A potential responsive sorbent for removal of organic pollutant from water. Desalination 281, 429-437. https://doi.org/10.1016/j.desal.2011.08.031

Shirzad-Siboni, M., Khataee, A., Hassani, A., Karaca, S., 2015. Preparation, characterization and application of a CTAB-modified nanoclay for the adsorption of an herbicide from aqueous solutions: Kinetic and equilibrium studies. Comptes Rendus Chimie 18, 204-214. https://doi.org/10.1016/j.crci.2014.06.004

Shrestha, N.K., Wang, J., 2020. Water quality management of a cold climate region watershed in changing climate. Journal of Environmental Informatics 35, 56-80. https://doi.org/10.3808/jei.201900407

Slamova, R., Trckova, M., Vondruskova, H., Zraly, Z., Pavlik, I., 2011. Clay minerals in animal nutrition. Applied Clay Science. https://doi.org/10.1016/j.clay.2011.01.005

Soleimani, M., Amini, N., 2017. Remediation of environmental pollutants using nanoclays. Springer, Cham, pp. 279-289. https://doi.org/10.1007/978-3-319-46835-8_9

Sonawane, S.H., Chaudhari, P.L., Ghodke, S.A., Parande, M.G., Bhandari, V.M., Mishra, S., Kulkarni, R.D., 2009. Ultrasound assisted synthesis of polyacrylic acid-nanoclay nanocomposite and its application in sonosorption studies of malachite green dye. $\begin{array}{llll}\text { Ultrasonics } & \text { Sonochemistry 351-355. }\end{array}$ https://doi.org/10.1016/j.ultsonch.2008.10.008

Souza, P.M.S., Morales, A.R., Marin-Morales, M.A., Mei, L.H.I., 2013. PLA and montmorilonite nanocomposites: properties, biodegradation and potential toxicity. Journal of Polymers and the Environment 21, 738-759. https://doi.org/10.1007/s10924-013-0577-z 
Stephenson, R.J., Duff, S.J.B., 1996. Coagulation and precipitation of a mechanical pulping effluent - I. Removal of carbon, colour and turbidity. Water Research 30, 781-792. https://doi.org/10.1016/0043-1354(95)00213-8

Stepova, K. V., Maquarrie, D.J., Krip, I.M., 2009. Modified bentonites as adsorbents of hydrogen sulfide gases. Applied Clay Science 42, 625-628. https://doi.org/10.1016/j.clay.2008.05.001

Stern, S.T., McNeil, S.E., 2008. Nanotechnology safety concerns revisited. Toxicological Sciences 101, 4-21. https://doi.org/10.1093/toxsci/kfm169

Stevenson, F.J., 1994. Humus chemistry: genesis, composition, reactions, 2nd Edition | Wiley, John Wiley.

Storhaug, E. and, 1986. Odour prevention and control of organic sludge and livestock farming. Taylor \& Francis, Abingdon, UK. https://doi.org/10.4324/9780203215593

Theng, B.K.G., Walker, G.F., 1970. Interactions of clay minerals with organic monomers. Israel Journal of Chemistry 8, 417-424. https://doi.org/10.1002/ijch.197000048

Turk, A., Sakalis, E., Lessuck, J., Karamltsos, H., Rago, O., 1989. Water pollution control: Diibendorf, Switzerland, 1986. (29) Reichert, P.; Wanner, O. In proceedings of the twelfth congress of the international association of hydraulic research, organophosphorous insecticides . A general introduction; World Health Organization. Uddin, F., 2008. Clays, nanoclays, and montmorillonite minerals. Metallurgical and Materials Transactions A: Physical Metallurgy and Materials Science 39, 2804-2814. https://doi.org/10.1007/s11661-008-9603-5

Uddin, M.K., 2017. A review on the adsorption of heavy metals by clay minerals, with special focus on the past decade. Chemical Engineering Journal 308, 438-462. https://doi.org/10.1016/j.cej.2016.09.029

Velizarov, S., Crespo, J.G., Reis, M.A., 2004. Removal of inorganic anions from drinking water supplies by membrane bio/processes. Reviews in Environmental Science and 
Biotechnology 3, 361-380. https://doi.org/10.1007/s11157-004-4627-9

Velizarov, S., Matos, C., Oehmen, A., Serra, S., Reis, M., Crespo, J., 2008. Removal of inorganic charged micropollutants from drinking water supplies by hybrid ion exchange membrane processes. Desalination 223, 85-90. https://doi.org/10.1016/j.desal.2007.01.217

Vlastou, E., Gazouli, M., Ploussi, A., Platoni, K., Efstathopoulos, E.P., 2017. Nanoparticles: nanotoxicity aspects. Journal of Physics: Conference Series 931. https://doi.org/10.1088/1742-6596/931/1/012020

Vorobyov, I., Anisimov, V.M., Greene, S., Venable, R.M., Moser, A., Pastor, R.W., MacKerell, A.D., 2007. Additive and classical drude polarizable force fields for linear and cyclic ethers. Journal of Chemical Theory and Computation 3, 1120-1133. https://doi.org/10.1021/ct600350s

Wagner, A., 2018. Toxicity evaluations of nanoclays and an associated nanocomposite throughout their Life Cycle 1-177.

Wang, W., Huang, G., An, C., Zhao, S., Chen, X., Zhang, P., 2018. Adsorption of anionic azo dyes from aqueous solution on cationic gemini surfactant-modified flax shives: Synchrotron infrared, optimization and modeling studies. Journal of Cleaner Production 172, 1986-1997. https://doi.org/10.1016/j.jclepro.2017.11.227

Wang, X., Jiang, M., Zhou, Z., Gou, J., Hui, D., 2017. 3D printing of polymer matrix composites: A review and prospective. Composites Part B: Engineering 110, 442-458. https://doi.org/10.1016/j.compositesb.2016.11.034

Wasan, D.T., Nikolov, A.D., 2003. Spreading of nanofluids on solids. Nature 423, 156-159. https://doi.org/10.1038/nature01591

Watabe, Y., Yamada, K., Saitoh, K., 2011. Hydraulic conductivity and compressibility of mixtures of nagoya clay with sand or bbntonite. Geotechnique 61, 211-219. https://doi.org/10.1680/geot.8.P.087 
Williams, L.B., Holland, M., Eberl, D.D., Brunet, T., De Courrsou, L.B., 2004. killer clays! natural antibacterial clay minerals. Mineralogical Society Bulletin 3-8.

Xin, X., Huang, G., An, C., Lu, C., Xiong, W., 2020. Exploring the biophysicochemical alteration of green alga Asterococcus superbus interactively affected by nanoparticles, triclosan and illumination. Journal of Hazardous Materials 398, 122855. https://doi.org/10.1016/j.jhazmat.2020.122855

Xin, X., Huang, G., An, C., Raina-Fulton, R., Weger, H., 2019. Insights into long-term toxicity of triclosan to freshwater green algae in lake erie. Environmental Science and Technology 53, 2189-2198. https://doi.org/10.1021/acs.est.9b00259

Xu, H.L., Lu, S., 1997. [Care of patients with cavernous hemangioma of the large bowel: report of 3 cases]. Zhonghua hu li za zhi $=$ Chinese journal of nursing 32, 511-3.

Yadav, V.B., Gadi, R., Kalra, S., 2018. Synthesis and characterization of novel nanocomposite by using kaolinite and carbon nanotubes. Applied Clay Science 155, 30-36. https://doi.org/10.1016/j.clay.2017.11.043

Yahiaoui, F., Benhacine, F., Ferfera-Harrar, H., Habi, A., Hadj-Hamou, A.S., Grohens, Y., 2014. Development of antimicrobial PCL/nanoclay nanocomposite films with enhanced mechanical and water vapor barrier properties for packaging applications. Polymer Bulletin 72, 235-254. https://doi.org/10.1007/s00289-014-1269-0

Yang, J., Tighe, S., 2013. A Review of advances of nanotechnology in asphalt mixtures. Procedia - Social and Behavioral Sciences 96, 1269-1276. https://doi.org/10.1016/j.sbspro.2013.08.144

Yang, X., Huang, G., An, C., Chen, X., Shen, J., Yin, J., Song, P., Xu, Z., Li, Y., 2021. Removal of arsenic from water through ceramic filter modified by nano-CeO2: A costeffective approach for remote areas. Science of the Total Environment 750, 141510. https://doi.org/10.1016/j.scitotenv.2020.141510

Yeom, C., Kim, Y., 2017. Adsorption of ammonia using mesoporous alumina prepared by 
a templating method. Environmental Engineering Research 22, 401-406. https://doi.org/10.4491/eer.2017.045

Yuan, G., 2004. Natural and modified nanomaterials as sorbents of environmental contaminants. Journal of Environmental Science and Health, Part A 39, 2661-2670. https://doi.org/10.1081/ESE-200027022

Yuan, G., Wu, L., 2007. Allophane nanoclay for the removal of phosphorus in water and wastewater. Science and Technology of Advanced Materials 8, 60-62. https://doi.org/10.1016/j.stam.2006.09.002

Yuan, Q., Zhao, Y.P., 2010. Precursor film in dynamic wetting, electrowetting, and electroelasto- capillarity. Physical Review Letters 104, 246101. https://doi.org/10.1103/PhysRevLett.104.246101

Zhang, B., Matchinski, E.J., Chen, B., Ye, X., Jing, L., Lee, K., 2018. Marine oil spills-oil pollution, sources and effects, in: World Seas: An Environmental Evaluation Volume III: Ecological Issues and Environmental Impacts. Elsevier, pp. 391-406. https://doi.org/10.1016/B978-0-12-805052-1.00024-3

Zhang, K., Jia, N., Li, S., Liu, L., 2018. How surfactant-decorated nanoparticles contribute to thermodynamic miscibility. Nanotechnology 29, 475701. https://doi.org/10.1088/1361-6528/aadb1d

Zhang, L., De Schryver, P., De Gusseme, B., De Muynck, W., Boon, N., Verstraete, W., 2008. Chemical and biological technologies for hydrogen sulfide emission control in sewer systems: A review. Water Research. https://doi.org/10.1016/j.watres.2007.07.013

Zhang, M., Lu, Y., Li, X., Chen, Q., Lu, L., Xing, M., Zou, H., He, J., 2010. Studying the cytotoxicity and oxidative stress induced by two kinds of bentonite particles on human B lymphoblast cells in vitro. Chemico-Biological Interactions 183, 390-396. https://doi.org/10.1016/j.cbi.2009.11.023 
Zhang, Y., Huang, G., An, C., Xin, X., Liu, X., Raman, M., Yao, Y., Wang, W., Doble, M., 2017. Transport of anionic azo dyes from aqueous solution to gemini surfactantmodified wheat bran: Synchrotron infrared, molecular interaction and adsorption studies. Science of the Total Environment 595, 723-732. https://doi.org/10.1016/j.scitotenv.2017.04.031

Zhao, S., Huang, W.W., Wang, X.Q., Fan, Y.R., An, C.J., 2019a. Sorption of phenanthrene onto diatomite under the influences of solution chemistry: A study of linear sorption based on maximal information coefficient. Journal of Environmental Informatics 34, 35-44. https://doi.org/10.3808/jei.201600329

Zhao, S., Huang, W.W., Wang, X.Q., Fan, Y.R., An, C.J., 2019b. Sorption of phenanthrene onto diatomite under the influences of solution chemistry: A study of linear sorption based on maximal information coefficient. Journal of Environmental Informatics 34, 35-44. https://doi.org/10.3808/jei.201600329

Zhong, L., Fu, S., Peng, X., Zhan, H., Sun, R., 2012. Colloidal stability of negatively charged cellulose nanocrystalline in aqueous systems. Carbohydrate Polymers 90, 644-649. https://doi.org/10.1016/j.carbpol.2012.05.091

Zhu, Z., Zhang, B., Cai, Q., Ling, J., Lee, K., Chen, B., 2020. Fish waste based lipopeptide production and the potential application as a bio-dispersant for oil spill control. Frontiers in Bioengineering and Biotechnology 8. https://doi.org/10.3389/fbioe.2020.00734 